ABORIGINAL HISTORY 1988 12:2

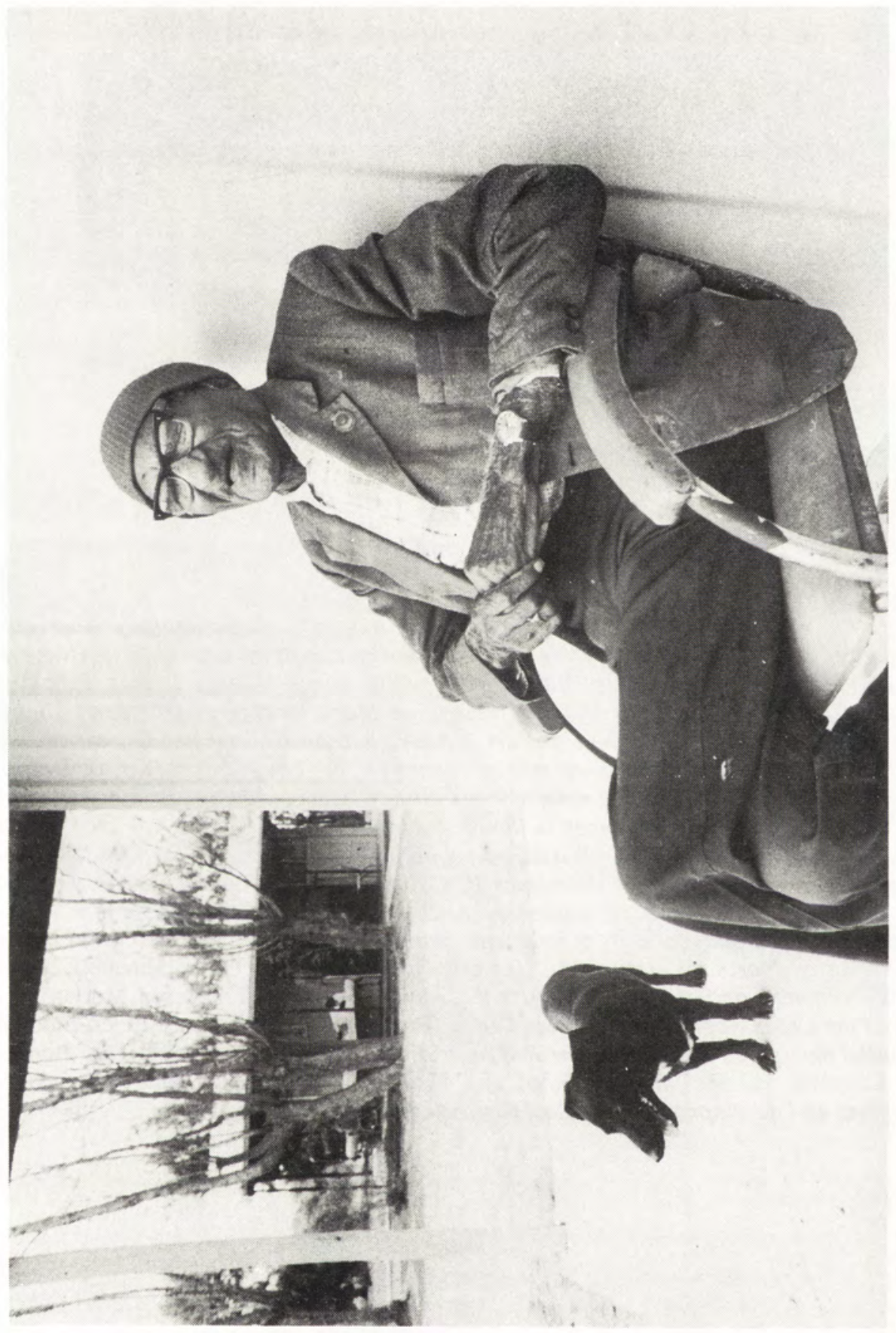

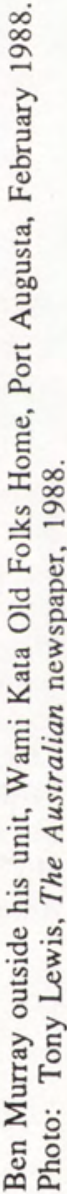




\title{
BEN MURRAY (PARLKU-NGUYU-THANGKAYIWARNA)
}

\author{
Peter Austin, Luise Hercus and Philip Jones
}

\section{Introduction}

According to the records he himself meticulously kept, Ben Murray was bom near Marree, northern South Australia, in 1891 to an Aboriginal mother and a Baluchistani (Afghan) father. Today Ben is the oldest resident of Amewarra Old People's Home in Port Augusta, in retirement after a long and eventful working life. ${ }^{1}$

In days when the emphasis is often placed on communities and spokespersons, Ben Murray is something totally different: a rugged individualist who stood in a unique and solitary position to Aboriginal society, to Afghan society, and to the white missionaries, station owners and managers for whom he worked. Ben is a strong person, both physically and mentally; he did not like compromises and hated injustice. This is evident not only from the events of his life that he recounted to us, but also from the comments of his friends and acquaintances. When Luise Hercus first met him in 1965 an event occurred which illustrates his attitudes perfectly. A station in the area had appointed a manager who was an alcoholic. The manager's young wife was just recovering from the birth of her second baby. There was a mid-January heatwave and a major drought was on; sheep were getting bogged in muddy dams and dying pitifully in their hundreds. The people on the other stations in the area were busy saving their own sheep, so the young wife sought help from Ben. He came at once. He walked into the homestead and found the manager lying drunk in bed. Without the slightest hesitation Ben told him what he thought of him and finished up saying: 'Get up, get dressed, and help me pull the sheep out! Otherwise I shall do it on my own, not for your sake, but for your wife and to save the sheep.' He went out alone and carried out the back-breaking task of rescuing the sheep.

Luise Hercus originally met Ben Murray in 1965, having been referred to him as a person who might be able to help her with her study of the Arabana and Wangkangurru languages, two closely related Aboriginal languages traditionally spoken to the west and north of Lake Eyre. Luise soon discovered the depth and range of Ben's knowledge of language and tradition, and of history, both Aboriginal and European. She worked with Ben from 1968, mainly on Wangkangurru but also collecting vocabulary and stories in Diyari, which is a completely different language originally spoken to the east of Lake Eyre that Ben had leamed as a child. They also recorded material on the Thirrari language, which is closely related to Diyari and was spoken along the eastern and southern shores of the Lake. Ben leamed Thirrari from his maternal grandmother and he is the last person to speak it fluently.

Peter Austin is Senior Lecturer in the Department of Linguistics, La Trobe University; Luise Hercus is Reader in the Faculty of Asian Studies, Australian National University; Philip Jones is Curator of Social History, Anthropology Division, South Australian Museum. All three have worked extensively in the Lake Eyre Basin.

1 For comments on earlier drafts of this biography we are grateful to Randy Austin and William McGregor, neither of whom is responsible for remaining infelicities. 


\section{ABORIGINAL HISTORY 1988 12:2}

Peter Austin first heard Ben's voice in 1972 when writing a student essay based upon Luise Hercus's tapes, and was introduced by her to Ben in January 1974 at the beginning of his field research for fourth-year honours in Linguistics. Between 1975 and 1977 Ben worked with Peter, teaching him Diyari and Thirrari for his doctoral research, ${ }^{2}$ including taperecording of many hours of texts in both languages.

Philip Jones was introduced to Ben Murray at Port Augusta in 1981 by Luise Hercus. He first interviewed Ben on the subject of red ochre expeditions in the Lake Eyre region ${ }^{3}$ and on the history of the Lutheran mission at Killalpaninna. ${ }^{4}$ An interest in Ben's own life history emerged from these discussions and Philip has recorded several interviews with Ben on this topic during the past seven years.

When discussing the writing of this biography recently, someone asked Luise Hercus: "Did you interview Ben Murray?" The question seemed absurd. Neither Luise Hercus nor Peter Austin 'interviewed' Ben Murray about his life. He was our helper, adviser and companion over a number of field-trips in the far north-east of South Australia; a friend we always look forward to seeing again. Scattered throughout our fieldtapes and notes are stories, describing events from a rich and varied life spent throughout eastern South Australia, from the sheep and cattle stations along the Birdsville track in the north to Waikerie, the Riverland and Pinnaroo in the south-east, and Kadina and Moonta on the Yorke Peninsula. What Ben Murray himself recounted of his life was told in episodic fashion, often in the context of 'having a yarn', and never arranged chronologically. It is as a result of Philip Jones' research that we are able to place the details of Ben's life in historical order and to write a more traditional biography.

In Australia there has been a lack of attention to the recording of the life histories of Aboriginal people. This contrasts with the United States, for example, where there has been a rich tradition of biographical writing about the lives of Native Americans beginning in $1825 .^{5}$ As White, Barwick and Meehan have pointed out:

In most anthropological and historical narratives about Aboriginal society the Aborigines themselves are nameless. Published life histories are rare, and most adhere to European conventions about biographical literature: reminiscences are edited to fit a chronological format which emphasises individual personality but omits the wealth of genealogical information and commentary on community values intrinsic to Aboriginal styles of recounting the past. Editors and publishers who reshape such narratives by excising what seems to them irrelevant may believe their attempts to portray Aboriginal lives in a European fashion make Aborigines more intelligible to outsiders. But the style is part of the story. Such omissions may impoverish the portrayal so that readers cannot perceive why Aboriginal life, however different, has its own satisfactions. 6

While we agree with the sentiments expressed here, it is interesting to note that not a single biography in the collection edited by White, Barwick and Meehan pays any attention to the language of the life histories told by their subjects and incorporated into the

2 See Austin 1978, published in revised form as Austin 1981. Fieldwork was supported by grants from the Australian National University.

3 Jones 1984; Jones, Austin and Hercus (forthcoming).

4 Jones and Sutton 1986.

5 See Langness and Frank 1981:15-29.

6 White, Barwick and Meehan 1985:xvi. 


\section{BEN MURRAY}

narratives written by the several authors in standard English. Not a single quotation in an Aboriginal language is included in the book, and nothing is said about the style, transcription or editing of the English used by the Aborigines and 'quoted' by the authors. An alternative approach is to be found in the collection of historical narratives in Hercus and Sutton 1986. Here, narrative texts are presented in a number of Aboriginal languages and given morpheme-by-morpheme glosses and free translations into idiomatic English.

As the editors note:

Something is inevitably lost in free English translations, whether these are made by the authors themselves or by translators. The real spirit of the authors' intentions, and especially their verbal humour and style, can only be caught from a close look at the versions given in the original languages. ${ }^{7}$

Unfortunately, as McGregor has pointed out, in some instances the transcribers, who were all linguists, have heavily edited the 'original' texts, deleting repetitions and removing from them commentary in English (which is however incorporated in the translations). Additionally, some of the transcribers have failed to provide sufficient historical and biographical background information to make the texts easily accessible to European readers. While we can decry the lack of representation of Aboriginal voices in 'standard' European histories, it is also important to realise that reading texts in another language is an exercise of skill and as such calls for assistance on the part of transcribers and translators. Our solution has been to try to retain the flavour of Ben Murray's original telling of his life history by incorporating in the texture of this account some of the dozens of stories he told us in the words that he himself used. We thus present a selection of texts in Arabana-Wangkangurru and Diyari-Thirrari (complete with repetitions and comments in English), together with interlinear glosses and free translations into English embedded within the narrative of Ben's life history. We hope that by doing this we can meet the twin aims of telling a good story while at the same time giving the reader an idea of the way Ben tells it himself.

\section{Early Life: Living at Muborina}

Ben Murray was born near the Frome Creek, just east of Marree in northern South Australia, in 1891. He was named Parlku-nguyu-thangkayiwarna, which in ArabanaWangkangurru means 'A Bank of Clouds Settling Down' and comes from the rain history. His mother, Karla-warru (later known as Anne Murray, then Merrick), was a part-Arabana, part-Thirrari woman whose own country was Kudnangampa on Stuart's Creek, south of Lake Eyre. Her father was an important Arabana man known as 'King Walter', who is described in Text $\mathrm{C}$ below. Her mother, Ben's grandmother (kadnhini mother's mother), was Kuriputhanha, a Thirrari woman known to the local white people as 'Queen Annie'.8 Ben's father was Bejah Dervish, later to achieve fame as the cameleer on the Calvert Exploring Expedition of $1896.9^{9}$ He had arrived in Australia as a young man of twenty-four in 1891, twenty-five years after Sir Thomas Elder organised the first Australian shipment of camels together with their Baluchistan handlers. The government recognised the value of this new labour source for the outback but stipulated that no Afghan women were to come

7 Hercus and Sutton 1986:29.

8 Ben reports that she died in the 1930s. Even in 1906 there were reported to be only five Thirrari alive (Gregory 1906:61), although the Diyari were claimed to number one hundred at that time.

9 Litchfield 1983:65-70; Farwell 1950:26; Raikowski 1987. 
ABORIGINAL HISTORY 1988 12:2

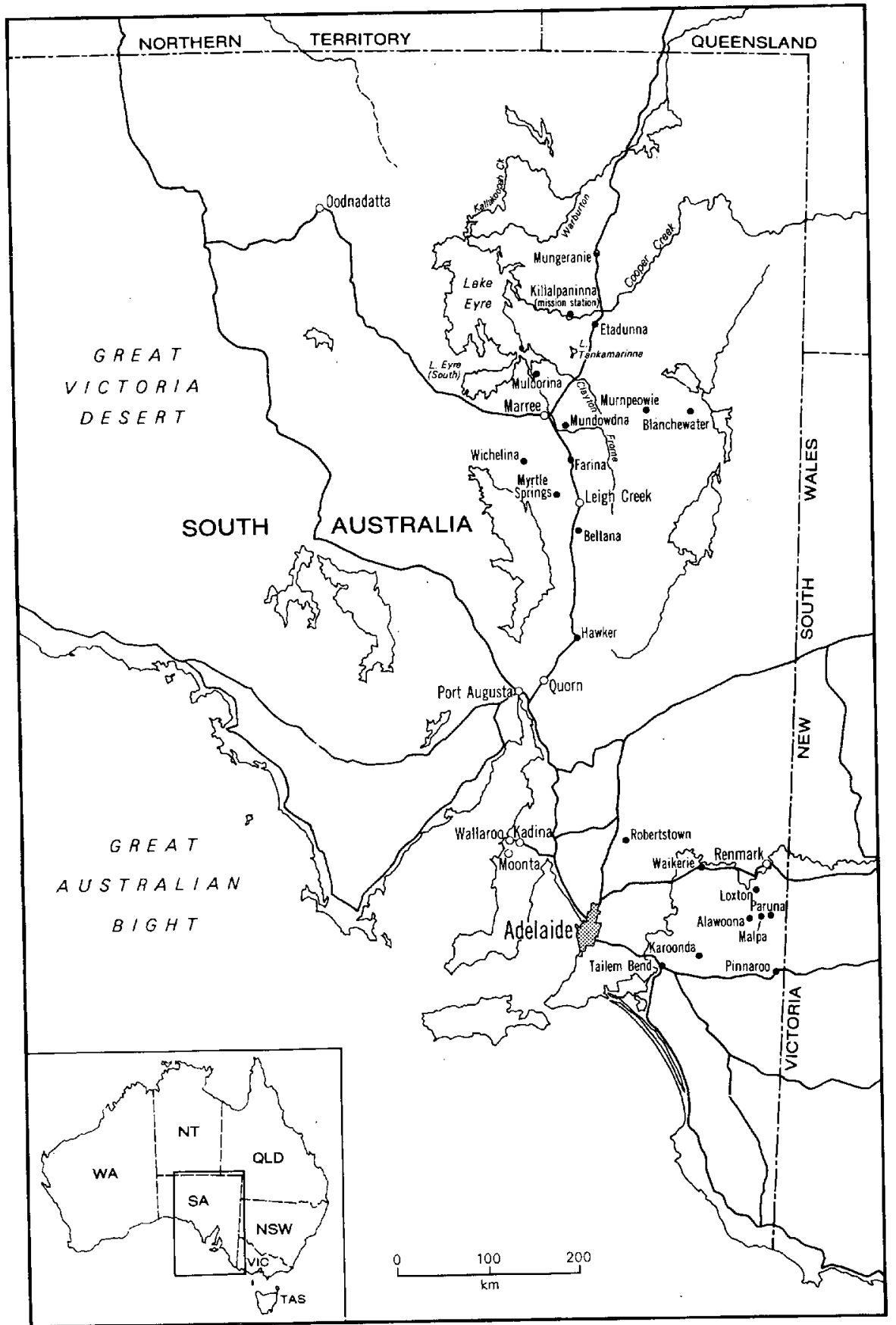

Ben Murray's country.

del. Cartography Unit, RSPacS, ANU. 


\section{BEN MURRAY}

to Australia. The authorities had a strong fear of duplicating, even in miniature, the racial and social problems of the Victorian and Northern Territory goldfields by allowing a new ethnic group to gain a foothold in South Australia. Afghan men soon formed liaisons with Aboriginal women, often short in duration and against their will. Ben's parents may well have met under such conditions. ${ }^{10}$

The town camp by the Frome Creek outside Marree was Ben's mother's home at the time of his birth in 1891. Ben's earliest years were spent here in this half-bush, half-town camp, within earshot of the railway steam-whistle. The people there were predominantly Wangkangurru and Arabana and Ben grew up with these as his first languages. By the time he was four or five however, his mother, sisters Shirley and Myra ${ }^{11}$, and brothers Ern and George had moved to Muloorina Station, east of Lake Eyre South in traditional Thirrari country. One likely reason for the move was that his mother had married a Wangkangurru man from the Simpson Desert who was employed on the station. Another was that his grandmother, Kuriputhanha 'Queen Annie' lived there.

Ben learnt the Thirrari language from his grandmother and is now its only surviving speaker. As Text A shows, Ben was also exposed to the traditional ways of his mother's people and learnt a large amount from them. Already though, at this young age, he was learning to operate between the Aboriginal and European cultures. The following anecdote, related to Eric Bonython by Ben's brother Ern, conveys something of this. It probably describes an event that took place on Muloorina and must have concerned Walter, the boys' grandfather.

Talking of tracking reminds me [Em] of when I was a boy and I examined the witch doctor's bag of tricks. He was held in great fear by the tribe and he always had his bag of charms or curses hanging in a tree outside his wurlie. My brother Ben and I had always wanted to see what was in it, but were afraid to, because he would have known our footprints.

So we waited until a day when he was away and I got a horse that we could ride and we went up to the tree and took the bag. We were very curious, for no-one had ever seen inside it before. Inside the skin bag were all sorts of coloured stones and little flint knives and what looked like gold in little pieces and several bones. Then we returned it just as it was, and got away as fast as we could. Next day, the old fellow caught us and asked if we had been at his bag. Although we said we hadn't he didn't quite believe us, as he said our horse had been there anyway. We hadn't thought of that. ${ }^{12}$

The boys' grandfather, Walter, was a ceremonial leader of the Arabana people and young Ben learnt much from him. One of Ben's earliest memories is of accompanying the old man through Arabana country to Stuart's Creek at Kudnampa to attend a ceremony there. Walter showed Ben some of the special places in his country there: 'showing me country, all around Anna Creek and everywhere, Stuart's Creek. ${ }^{13}$ Ben's grandmother showed him

10 Hercus 1985.

11 Myra may have been born later at Muloorina Station; Ben does not recall any details of her later life.

12 Bonython 1971:179.

13 Ben Murray interviewed by Phillip Jones on 1 February 1988. Further quotations from Murray-Jones interviews below are referenced as M-J plus the relevant date, as here M-J, 1.2.88. Tapes of the Murray-Jones interviews are in Jones' possession; copies are to be deposited in the South Australian Museum archives, and at the Australian Institute of Aboriginal Studies. The tape transcriptions have been slightly edited here through the 


\section{ABORIGINAL HISTORY 1988 12:2}

the country on the west side of Lake Eyre and one trip took the family by foot as far north as Birdsville, following the Kallakoopah north from the Lake. This trip was also apparently for ceremonial business as well as for meeting relatives and friends,

'...we mix up with the people, have a corroboree there...[and]...a bit of a look

around the country...' 14

The older Wangkangurru men in the Marree area, such as Ben's step-father, still carried on much of their traditional life-style, and young Ben observed their ways. The two most senior of these men were Ngatu-thakali, known as 'Rib-bone Billy', ${ }^{15}$ and Punjili. The first three texts are extracts of Ben's account of his Muloorina days showing how the old men preserved various aspects of their traditional life, leaving the women and children behind in their camp depending on rations. The language of the texts is Wangkangurru, and there are passages of English: ${ }^{16}$

removal of fillers such as 'er', coughing and silences, and the standardisation of the grammar to make the quotations more easily understandable.

See Hercus 1976. There is a photograph of 'Koonkoo Nutatucullie' (as George Aiston called him) in Jones and Sutton 1986:55.

16 Each episode from Ben's life story told in an Aboriginal language will be presented as a text with morpheme-by-morpheme glosses for each word and then a free translation at the end. The texts recorded by Hercus are split into numbered sections, the division on the whole in accordance with intervals in speech. For the texts collected by Austin each sentence is numbered and there is an identification of the place and date of recording, the fieldtape number of the relevant tape-recording, and book and page number of the tape transcriptions. The texts incorporated here were retranscribed in October 1987. Copies of all of Austin's tapes and transcriptions are held at the Australian Institute of Aboriginal Studies, Canberra. In this paper practical orthographies have been used for Wangkangurru and Diyari-Thirrari. Plosive consonants other than the retroflex have been written as unvoiced: $p, k, t h, t$ (in Diyari-Thirrari there is a voicing contrast for medial retroflex stops, and also a contrast between medial $n t$ and $n d r r$ ). Prestopped nasals and laterals have been written with a voiced stop component as this corresponds most closely to the pronunciation, hence $b m, d n, d n h, d n j, d l, d l h$. Retroflexes have been written as $r$ plus consonant, i.e. $r l$ is a retroflex lateral, $r n$ is a retroflex nasal, and $r d$ and $r t$ are retroflex stops. Interdentals have been written as consonant plus $h$, hence $l h, n h, t h$. For Wangkangurru palatals have been written as consonant plus $j$, hence $t j, n j, l j$. In Diyari-Thirrari the corresponding symbols are $j, n y, l y$. The Lake Eyre languages have three r-sounds: a trill, a flap, and a continuant. For Wangkangurru these are written as $r r, r$, and $R$ respectively, and for Diyari-Thirrari as $r r h, r r$, and $r$. Abbreviations used for linguistic terms in the inter-linear glosses are: ABL - ablative case; ACC - accusative case; ACT - active stem-forming suffix; ADD - additional information; ADV - adverbial suffix; ALL - allative case; ALT - altruistic stem-forming suffix; ANC - ancient past; AUX - auxiliary verb; CAUS - causaul case; CONT continuous participle; CONT S - continuous stem-forming suffix; DEF - definite; EMPH emphatic clitic; ERG - ergative case; EXCL - exclusive pronoun; HAB - habitual aspect; HIST - historical past; IDENT - identified information; IMP - imperfective; IMPER imperative; IMPL DS - implicated clause different-subject; IMPL SS - implicated clause same- subject; INCHOAT - inchoative verbaliser; INCL - inclusive pronoun; LOC locative case; MASC PN - masculine proper name; NAR - narrative past; NI - new information; NOMIN - nominative case; OI - old information; PAST - past tense; PERF perfect; PLUP - pluperfect; POS - possessive suffix; PRES - present tense; PTCPLE participle; PUNC - punctiliar aspect; PURP - purposive; REL DS - relative clause different-subject; REL SS - relative clause same-subject; SP - speed form (action before 


\section{BEN MURRAY}

TEXT A 'Rib-Bone Billy'

Recorded by Luise Hercus in February 1976

$\begin{array}{llll}\text { 1. Ngatu-thakali } & \text { uka } & \text { waya-rnda } & \text { tharni-lhiku puntju } \\ \text { Rib-bone Billy } & \text { he } & \text { wish-PRES } & \text { eat-PURP }\end{array}$

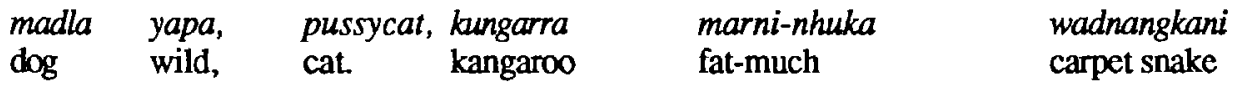

marni-nhuka anla tharni-lhiku waya-mda.

fat-much true eat-PURP wish-PRES.

$\begin{array}{cllll}\text { 2. Tjarlpa } & \text { thangki-rda, } & \text { puntju-ku } & \text { waya-rnda. } & \text { Puntju } \\ \text { Food } & \text { keep-PRES } & \text { meat-DAT } & \text { desire-PRES. } & \text { meat }\end{array}$

$\begin{array}{llll}\text { tharni-lhiku. } & \text { Malka } & \text { malju-mayi } & \text { tharni-lhiku-thu! } \\ \text { eat-HIST } & \text { not } & \text { grain-food } & \text { eat-PURP-EMPH }\end{array}$
3. Ai, kathi-nga
yuka-lhuku waya-mia
tharni-lhiku
Ay, meat-LOC go-PURP wish-PRES eat-PURP

$\begin{array}{lllll}\text { wadnhi-naru } & \text { maka-nga. } & \text { Ah! Mayi! arlali } & \text { mardu-purru } \\ \text { cook-PLUP } & \text { fire-LOC } & \text { Ah! Hey! } & \text { at last } & \text { sweet-having }\end{array}$

tharni-lhiku.

eat-PURP

4. 'It's sweeter the way I cook it !' That is what he used to live on, only meat.

5. His second wife was Rosie and they lived down in the Muloorina country. That is where he settled down because we were there.

\section{Translation}

1.Rib-bone Billy wanted to eat meat, dingos, feral cats, plump kangaroos and fat carpetsnakes, that is what he really liked to eat.

2. He used to have flour there, but it was meat he really wanted. 'I don't like vegetable food!' (he used to say).

3. What he really liked was going out hunting, and to eat meat cooked in the ashes. 'At last here is something full of sweet flavour', he used to say.

4. 'It's sweeter the way I cook it !' That is what he used to live on, only meat.

5. His second wife was Rosie and they lived down in the Muloorina country. That is where he settled down because we were there.

departing); SPEC - specific; TR - transitory aspect; TRANS - transitiviser; TRVB transitive verbaliser (causative). 
TEXT B 'Punjili'

$\begin{array}{lllll}\text { 1. Muyu } & \text { nguru } & \text { thangka-rda } & \text { kanhangarda, } & \text { thika-rnda } \\ \text { Day } & \text { other } & \text { stay-PRES } & \text { there } & \text { return-PRES }\end{array}$

$\begin{array}{llll}\begin{array}{l}\text { Marri-riku-lki, } \\ \text { Marree-ALL-FIN, }\end{array} & \begin{array}{l}\text { Marri-riku-lki } \\ \text { Marree-ALL-FIN }\end{array} & \begin{array}{l}\text { thika-rnda, } \\ \text { return-PRES }\end{array} & \begin{array}{l}\text { Mundowdna } \\ \text { Mundowdna }\end{array} \\ \begin{array}{l}\text { thika-rnda, } \\ \text { retum-PRES }\end{array} & \text { might be muyu } & \begin{array}{l}\text { nguyu, might be } \\ \text { day }\end{array} & \begin{array}{l}\text { muyu parkulu. } \\ \text { day two }\end{array}\end{array}$

$\begin{array}{llll}\text { 2. Tharpa-tharpa-rnda, } & \text { tharpa-arpa-mda } & \text { Punjili } & \text { pidlla. } \\ \text { trample on -PRES, } & \text { trample down-PRES } & \text { Punjili } & \text { name. }\end{array}$

3. He could go to the Kallakoopah and then go on to the desert. He used to travel around that way, and leave his wife. He would say :
4. Atha yuka-rnda-lki
I go-PRES-FIN
thidnangkara,
north
thidnangkara
north
antha
I

$\begin{array}{lllll}\text { yuka-rnda, } & \text { mayi! } & \text { nhanhi } & \text { ngarrkani } & \text { idni-rnda!' } \\ \text { go-PRES } & \text { hey! } & \text { look } & \text { moon } & \text { is-PRES }\end{array}$

5. Well that is the time he'd be back. He'd work it right too! Grandfather went too. Only my grandmother, and the other women stayed on living there, and maybe another man who was too old, and he was blind too. He was Diyari.

\section{Translation}

1. He (Punjili ) would stay there for a couple of days, and then go back to Marree. He would go to Marree, to Mundowdna and then he would be back again, maybe for one day, maybe for two.

2. 'Trampling underfoot' that is the meaning of the name Punjili.

3. He could go to the Kallakoopah and then go on to the desert. He used to travel around that way, and leave his wife. He would say :

4. 'I am going away now to the north, it is to the north that I am going. Hey, just look at the moon! That moon there, it must be just about half way between new and quarter!'

5. Well that is the time he'd be back. He'd work it right too! Grandfather went too. Only my grandmother, and the other women stayed on living there, and maybe another man who was too old, and he was blind too. He was Diyari.

\section{TEXT C. 'Cheeky Old Grandfather'}

Ben often spoke with affection of his grandfather, King Walter. In this text however he describes how King Walter, with increasing age, became more and more 'cheeky', that is to say aggressive. Ben, despite his love for the old man, passed a stern moral judgement on him.

1. Old grandfather was a 'cheeky' old fellow, an Arabana man. He got ten years for murdering a man. He wouldn't think twice (about killing someone)! He was deaf as a post! 


\section{BEN MURRAY}

2. Yarri-pudlu arla-kithi!!!

Deaf true-indeed!
Uka-ru kira

He-ERG boomerang kanti-rda. collect-PRES

\begin{tabular}{|c|c|c|c|c|}
\hline $\begin{array}{l}\text { kanti } \\
\text { wadddy }\end{array}$ & $\begin{array}{l}\text { kira } \\
\text { boomerang }\end{array}$ & $\begin{array}{l}\text { kanti-rda, } \\
\text { collect-PRES }\end{array}$ & $\begin{array}{l}\text { malka } \\
\text { not }\end{array}$ & $\begin{array}{l}\text { thurla thangki-rda, } \\
\text { stone-knife keep-PRES }\end{array}$ \\
\hline \multicolumn{3}{|c|}{ get a butcher knife! } & \multicolumn{2}{|l|}{$\begin{array}{l}\text { kurri-lhiku! } \\
\text { cut-PURP }\end{array}$} \\
\hline $\begin{array}{l}\text { 3. Nharla } \\
\text { Man }\end{array}$ & $\begin{array}{l}\text { nguru } \\
\text { other }\end{array}$ & $\begin{array}{l}\text { kuri-rnda! } \\
\text { cut-PRES }\end{array}$ & $\begin{array}{l}\text { Thurla } \\
\text { stone-knife }\end{array}$ & $\begin{array}{l}\text { kanti-rda, } \\
\text { collect-PRES }\end{array}$ \\
\hline $\begin{array}{l}\text { nharla } \\
\text { man }\end{array}$ & $\begin{array}{l}\text { nguru } \\
\text { other }\end{array}$ & $\begin{array}{l}\text { ru } \\
\text { knife-INST }\end{array}$ & $\begin{array}{l}\text { kurri-lhiku, } \\
\text { cut-HIST, }\end{array}$ & $\begin{array}{l}\text { kadnha-ru. } \\
\text { stone-INST. }\end{array}$ \\
\hline
\end{tabular}

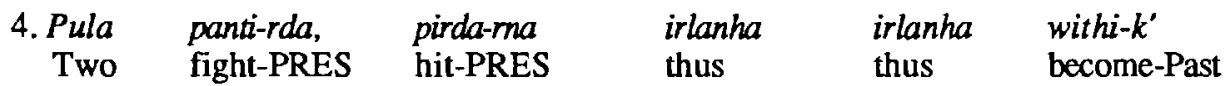

$\begin{array}{llllll}\text { uka arla } & \text { pirda-rna, } & \text { uka } & \text { manhi } & \text { yanta, thiRi-nhuka } \\ \text { he } & \text { true } & \text { strike-PRES } & \text { he } & \text { false } & \text { speak }\end{array}$

$\begin{array}{lllll}\text { uka } & \text { ngurrali! } & \text { Nharla } & \text { wantja-ngura, } & \text { uka-ru } \\ \text { he } & \text { altogether! } & \text { man } & \text { finish-CONT } & \text { he-ERG }\end{array}$

pirda-ka kumpira-ku.

strike-PAST dead-DAT.

5. He couldn't speak English much, Tim ${ }^{17}$ had to speak for him. Old King Walter murdered a man. He got ten years, and when he got out he murdered another one! They told me about it, I didn't actually see him do it! The police ${ }^{18}$ took him, they took him away to the court case. Tim Merrick, Selma's ${ }^{19}$ father, was witness (i.e spokesperson for him) because he was Arabana.
6. Ah mayi,
withira
uka
yani-thara
thara-marlka-na?
Eh go on,
how many
he say-IMM
thigh-stripe-EMPH?

Malka

thara-marlka,

akuru.

Not

thigh stripe

that one

17 Tim Merrick was one of the most respected members of the community at Killalpaninna Mission on the lower Cooper. It was said that he was equally fluent in Arabana, Diyari and English.

18 The Arabana-Wangkangurru word for police-man is thara-marlka, which literally means 'thigh-stripe', and refers to the uniform of the time.

19 There is a photograph of Selma Merrick (or Maltalina) in Jones and Sutton 1986:39. She was living in Marree at the time Ben related this text and later assisted Peter Austin in his Diyari research (see mention of Selma Thompson in Austin 1981:14). 


\section{ABORIGINAL HISTORY 1988 12:2}

$\begin{array}{llcccc}\begin{array}{l}\text { 7. Uka } \\ \text { He }\end{array} & \begin{array}{l}\text { anthi-rda } \\ \text { me-DAT }\end{array} & \begin{array}{l}\text { yani-rnda, eh, } \\ \text { tell-PRES hey }\end{array} & \begin{array}{l}\text { irliyangkuta } \\ \text { that many }\end{array} & \begin{array}{l}\text { madli } \\ \text { cold }\end{array} & \begin{array}{l}\text { ya } \\ \text { and }\end{array} \\ \begin{array}{l}\text { marutja } \\ \text { summer heat }\end{array} & \begin{array}{l}\text { anpa } \\ \text { you }\end{array} & \begin{array}{l}\text { tharka-nha! } \\ \text { stand-NP }\end{array} & \begin{array}{l}\text { Kanjangarri-nga. } \\ \text { gaol-LOC }\end{array}\end{array}$

8. But they let him out before. They had imprisoned him but they said, 'It is no good keeping the poor old thing, he doesn't know the rules! He had to defend himself, and so he did! It might have been a younger man than him annoying him, well in self-defence he might have done it.' But I, I put it that way, it was murder! I don't know what the argument was!

\begin{tabular}{|c|c|c|c|c|}
\hline $\begin{array}{l}\text { 9. Uka-ru } \\
\text { He-ERG }\end{array}$ & $\begin{array}{l}\text { pirda-ka! } \\
\text { kill-PAST }\end{array}$ & $\begin{array}{l}\text { Pirda-md' } \\
\text { kill-PRES }\end{array}$ & $\begin{array}{l}\text { uka-ru, } \\
\text { he-ERG, }\end{array}$ & $\begin{array}{l}\text { wka-nha } \\
\text { he-ACC }\end{array}$ \\
\hline $\begin{array}{l}\text { parda-rna, } \\
\text { take-PRES }\end{array}$ & $\begin{array}{l}\text { thika-rna. } \\
\text { retum-PRE }\end{array}$ & & & \\
\hline
\end{tabular}

$\begin{array}{llll}\begin{array}{c}\text { 10. Uka Frome } \\ \text { He }\end{array} & \begin{array}{l}\text { thangka-thika-lhuku, karla-nga, } \\ \text { sit-return-HIST }\end{array} & \begin{array}{l}\text { wardayapu } \\ \text { creek-LOC }\end{array} & \begin{array}{l}\text { yuka-mdack } \\ \text { track-PRES }\end{array}\end{array}$

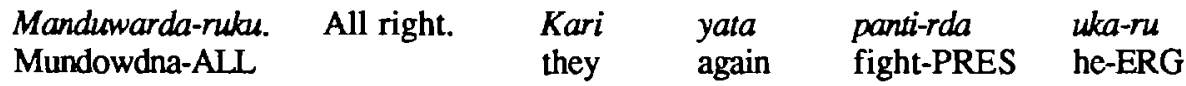

$\begin{array}{lll}\text { nguru-ki } & \text { pirda-nha-nga. } & \text { Anha. } \\ \text { other-EMPH } & \text { kill-NP-LOC. } & \text { Truly. }\end{array}$

$\begin{array}{clll}\text { 11. Warrangka-ru piti-kadnha } & \text { thawi-lhiku, } & \text { ah, } & \text { kira-nha } \\ \text { left-INST } & \text { weapon-stone } & \text { throw-HIST } & \text { ah } \\ \text { boomerang-EMPH }\end{array}$

$\begin{array}{llll}\text { punta-lira } & \text { nhiki } & \text { yani-nhurka-rna } & \text { eeeh' } \\ \text { break-LEST } & \text { this one } & \text { speak-swallow-IMP } & \text { oech }\end{array}$

12. It wouldn't matter if you sang out to him, he wouldn't hear, or he might think you were singing out to somebody else. He might run up and catch hold of you with his knife. Other people would be too frightened to catch hold of him (to stop him).
13. Thadlara
waya-rnda,
uka-ru katji-rna
arlali pirda-lhuku.
frightened become-PRES he-ERG turn-IMP
finally kill-HIST.

14. He been there, uka ngulpa-thi-rnda, might have been two or three months. he ill-become-PRES

$\begin{array}{llllll}\text { Ngurlpa } & \text { idni-mda, } & \text { malka } & \text { uka-ru } & \text { tharni-rnda, } & \text { kutha-li } \\ \text { sick } & \text { lie-PRES } & \text { not } & \text { he-ERG } & \text { eat-PRES } & \text { water-EMPH }\end{array}$

$\begin{array}{llll}\text { puntha-rda, } & \text { irlanha } & \text { uka-nha } & \text { manta-ka. } \\ \text { drink-PRES } & \text { thus } & \text { he-ACC } & \text { take-PAST }\end{array}$


BEN MURRAY

\section{Kutha-li water-EMPH}

puntha-nangka-rda, drink-CONT S-PRES

\section{malka tjarlpa not food}

tharni. Puntju eat. meat

\begin{abstract}
ngunhi-ngura,
\end{abstract} give-CONT

\section{tjarlpa}

food

\section{ngunhi-ngura.} give-CONT.

\section{Transkation}

1. Old grandfather was a 'cheeky' old fellow, an Arabana man. He got ten years for murdering a man. He wouldn't think twice (about killing someone)! He was deaf as a post!

2. He was stone deaf. He used to get together boomerangs, he wasn't so keen on stone knives, he would prefer to get a butcher's knife to slash someone.

3. He would cut another man to pieces! He did get some stone knives too, so that he could cut another man with a stone knife or a bit of rock.

4. Two of them (him and another man) would get into a fight and he would hit the other fellow. It would happen like this: he would strike the other man first, and then make out that he hadn't (started the fight). He was altogether too 'cheeky' and aggressive. The other man would die, he would wound him mortally.

5. He couldn't speak English much, Tim had to speak for him. Old King Walter murdered a man. He got ten years, and when he got out he murdered another one! They told me about it, I didn't actually see him do it! The police took him, they took him away to the court case. Tim Merrick, Selma's father, was witness (i.e spokesperson for him) because he was Arabana.

6. (Grandfather asked) 'How many (years) did he say, this policeman?' (Tim Merrick answered) 'He is not a policeman, that man,' i.e. he is the magistrate!

7. He said That many (holding up the ten fingers of both his hands) cold seasons and the same number of hot summers you will spend in gaol.'

8. But they let him out before. They had imprisoned him but they said, It is no good keeping the poor old thing, he doesn't know the rules! He had to defend himself, and so he did! It might have been a younger man than him annoying him, well in selfdefence he might have done it.' But I, I put it that way, it was murder! I don't know what the argument was!

9. But he did kill a man, he murdered someone. They took him away and let him go again.

10. He came back to stay by the Frome Creek, and then he went on the road to Mundowdna. All right (so far). But then he got into a fight yet again and killed yet another man. That is how it was:

11. He picked up a sharp stone and threw it with his left hand (saying) 'A boomerang might break, but this will make you swallow your words! Eeeh!'

12. It wouldn't matter if you sang out to him, he wouldn't hear, or he might think you were singing out to somebody else. He might run up and catch hold of you with his knife. Other people would be too frightened to catch hold of him (to stop him).

13. Pcople became frightened of him, he would just turn round and end up killing somebody.

14. After he had been there (by the Frome) for something like two or three months he grew very sick. He just lay there, sick, he couldn't eat, he only drank water. That is how (the illness) took him. He went on just drinking water, he wouldn't take food. People gave him meat and they gave him vegetable food, (but he couldn't eat it). 


\section{ABORIGINAL HISTORY 1988 12:2}

15. He had to die. He was down by the Frome creek. We used to go (visiting) there, you know where they have got the reserve, they called it mission.

\section{TEXT D 'Starting Work'}

Ben began his working life as he was to end it eighty years later - in the saddle. Muloorina had been owned by the Bosworth family since $1885^{20}$ and they were struggling to make a living on the station at the time that young Ben was camped there with his mother. She was given domestic duties and when Ben was only a child of about five, old Harry Bosworth thought he could start employing him on the station. His task was to operate a mechanical water pump, a couple of hours at a time. This is Ben's account, given to Luise Hercus in February 1976.

$\begin{array}{lccccc}\begin{array}{l}\text { 1. Antha } \\ \text { I }\end{array} & \begin{array}{l}\text { thaRi-thaRi } \\ \text { tiny }\end{array} & \begin{array}{c}\text { kari } \\ \text { they }\end{array} & \begin{array}{l}\text { thangka-rda, } \\ \text { stay-PRES, }\end{array} & \begin{array}{l}\text { anthunha } \\ \text { my }\end{array} & \begin{array}{l}\text { kaku } \\ \text { sister }\end{array} \\ \begin{array}{l}\text { katjiwiRi, } \\ \text { big }\end{array} & \begin{array}{l}\text { arni } \\ \text { we }\end{array} & \begin{array}{l}\text { thangka-lhuku } \\ \text { sit-HIST }\end{array} & \begin{array}{l}\text { kanhangarda, } \\ \text { there }\end{array} & \begin{array}{l}\text { mathapurda } \\ \text { old man }\end{array}\end{array}$

$\begin{array}{llll}\text { Bosworth, } & u k a & \text { ngarritii-mda } & \text { karla-rula. } \\ & \text { he } & \text { come down-PRES } & \text { creck-ALL }\end{array}$

2. He said to me: 'Come on, jump in this buggy! Me and you go down!'

$\begin{array}{llll}\text { 3. Arunha } & \text { yruka-mda } & \text { yata } & \text { yuka-lhuku! } \\ \text { we two } & \text { go-PRES } & \text { further } & \text { go PURP }\end{array}$

4. He said: 'I want you boys ${ }^{21}$ to ride this horse!'

$\begin{array}{cll}\text { 5. Antha walpa-rna } & \text { nhantu-nga. } \\ \text { I } & \text { mount-PRES } & \text { horse-LOC. }\end{array}$

6. You know they had this old-fashioned pump, you tum on the cog-wheel, and pull in right in the well and turn this wheel, a big wheel with a belt on it, this works it. There is a rod going in and another wheel works on that. There is a belt on this pump and it pumps the water into the little dam. So he yoked this mare up in this turn-out, and he put me up on top saying: 'Now you keep that horse going!' I was only little, I hung onto the saddle, going round and round. 'You right, keep on going boy!'

$\begin{array}{cllll}\text { 7. Antha } & \text { uka-inta } & \text { yarapa-li } & \text { uka } & \text { yuka-ngura nhani-lhiku } \\ \text { I } & \text { him-DAT } & \text { up-EMPH } & \text { he } & \text { go-CONT see-PURP }\end{array}$

damu-ruku. Damu tjaRi thaRi. irlinha. dam-ALL dam little thus

20 Bonython 1971:173.

21 Use of the word 'boys' suggests that Ben's younger brother Ern was included as well, however he would have been about four at the time, and probably did not start work until later. 


\title{
BENMURRAY
}

$\begin{array}{lll}\text { 8. Uka } & \text { yari-rnda } & \text { arlarli } \\ \text { he } & \text { say-PRES } & \text { finally }\end{array}$

$\begin{array}{cll}\text { 9. Athu } & \text { nhantu } & \text { kuti. } \\ \text { I } & \text { horse } & \text { pull back. }\end{array}$

10. My legs wouldn't reach on the flank, I just kept'em somewhere, anyhow.

$\begin{array}{cllll}\begin{array}{c}\text { 11. Nhantu } \\ \text { horse }\end{array} & \text { palku } & \text { kudni-rnda } & \text { thidna } & \text { ngarritji-lhiku. } \\ & \text { body } & \text { put-PRES } & \text { foot } & \text { get down-PURP }\end{array}$

12. You know that front bone there, I had to put my foot there to get down. He said:

'Can you pull that chain off?' I had a try you know, I couldn't do it, so he came and did it. 'It's full enough', he said, 'I'll take you back to camp'. He took me to the house, Muloorina homestead. He said: 'All right you wait! Missus will come out directly!' She came out with a cake and sandwiches but as soon as she gave me that I nicked off, I ran down to the camp.
13. Antha
I
thika-rnda
return-PRES
ngura-ruku!
camp-ALL

Old mathapurda say:

$$
\begin{aligned}
& \text { malju -mayi } \\
& \text { grain-food }
\end{aligned}
$$

\author{
puri-ma-rnda. \\ exist-TEMP-PRES
}

\section{Translation}

1. I was only tiny, and we were staying there (at Muloorina). My elder sister was there too, she was a big girl. We were all camped there. Old man Bosworth came down to us, down by the creek.

2. He said to me: 'Come on, jump in this buggy! Me and you go down!'

3. He and I set out to go.

4. He said: 'I want you boys to ride this horse!"

5. I got up on the horse.

6. You know they had this old-fashioned pump, you tum on the cog-wheel, and pull in right in the well and turn this wheel, a big wheel with a belt on it, this works it. There is a rod going in and another wheel works on that. There is a belt on this pump and it pumps the water into the little dam. So he yoked this mare up in this turn-out, and he put me up on top saying: 'Now you keep that horse going!' I was only little, I hung onto the saddle, going round and round. 'You right, keep on going boy!'

7. I was just up there going in his direction when he went up to the dam to have a look. It was only a little dam. That's how it was.

8. In the end, after a long time, he said: 'Stop!'

9. I pulled the horse back.

10. My legs wouldn't reach on the flank, I just kept'm somewhere, anyhow.

11. I had to put my foot against the body of the horse so that I could get down.

12. You know that front bone there, I had to put my foot there to get down. He said: 'Can you pull that chain off?' I had a try you know, I couldn't do it, so he came and did it. 'It's full enough', he said, 'I'll take you back to camp'. He took me to the house, Muloorina homestead. He said: 'All right you wait! Missus will come out directly!' 
She came out with a cake and sandwiches but as soon as she gave me that I nicked off, I ran down to the camp.

13. I went back to our camp and the old fellow said: 'Well, it is food.'

Ben's family camped at Muloorina on and off apparently until 1902, when the Bosworths finally abandoned the station after several years of drought. The government took over the station and operated it until 1906 as a camel farm, serving the northern route to Birdsville and beyond, and to Oodnadatta and the north-west. The family then moved back to Marree and Ben's mother found work at Mrs Murray's boarding house (situated on the site of the present Progress Hall), one of several small businesses which sprang up as the town's fortunes grew after the advent of the railway in 1884. Ben helped his mother there, doing odd jobs, and before long he must have come to know the town and its characters well. By now the family may have been living in the town itself, undoubtedly on the north (Aboriginal and Afghan) side of the railway line.

The fact that Ben's family took its name from his mother's employer, Mrs Murray, reflects an accepted practice of the times. It also indicates the lack of any close ties between Ben's father, Bejah Dervish, and the family. Ben saw very little of his father, although the cameleer would have been a regular visitor to the town and to its Islamic mosque. As Ben puts it:

I didn't go by his name because he wasn't interested in looking after us.

Mother had to carry on herself. ${ }^{22}$

When Ben came to learn the camel work a few years later he relied on other men for assistance rather than on his father.

As an able-bodied boy, Ben would have been in demand around Marree, but it is likely that from the age of ten or even earlier, his future was already tied to station work. It was probably during these years in Marree that Ben first met Sidney Kidman, the 'Cattle King', later to become the lease-holder of most of the pastoral land between Port Augusta and the Gulf of Carpentaria. In 1906 Kidman purchased the lease on Mundowdna Station (marndawardunha), which included the Clayton run (wayikalkunha). He chose the young Ben Murray to work on Clayton, probably with several other Aboriginal stockmen, and Ben remembers his time on this property as his first real job. At the age of fourteen or fifteen he would have been away from his family for the first time and was expected to do a full day's work. Kidman visited the station periodically with his daughters Edna and Blanche, on their way down from Queensland with cattle for the Adelaide markets. It was Edna who taught Ben to ride well:

[She] used to tie me on the saddle, Edna did. She can ride, that girl. Yeah, rough horse too...People would say, 'Who's them jackaroos there?' 'Oh, they're the boss's daughters!' They were girls, dress like boys. ${ }^{23}$

\section{TEXT E 'Working for the Frenchmen'}

Ben was probably at Clayton for only a few months before returning to his family at Marree. By the following year he was on Wire Yard station (Cannatulkaninna or Ngankumilkinha ), on the western boundary of the Lutheran mission at Killalpaninna. His new employers were the de Pierre brothers, two Frenchmen who took up the pastoral lease there in 1906, four years after it was abandoned by the Bosworths. ${ }^{24}$ The de Pierres took 


\section{BEN MURRAY}

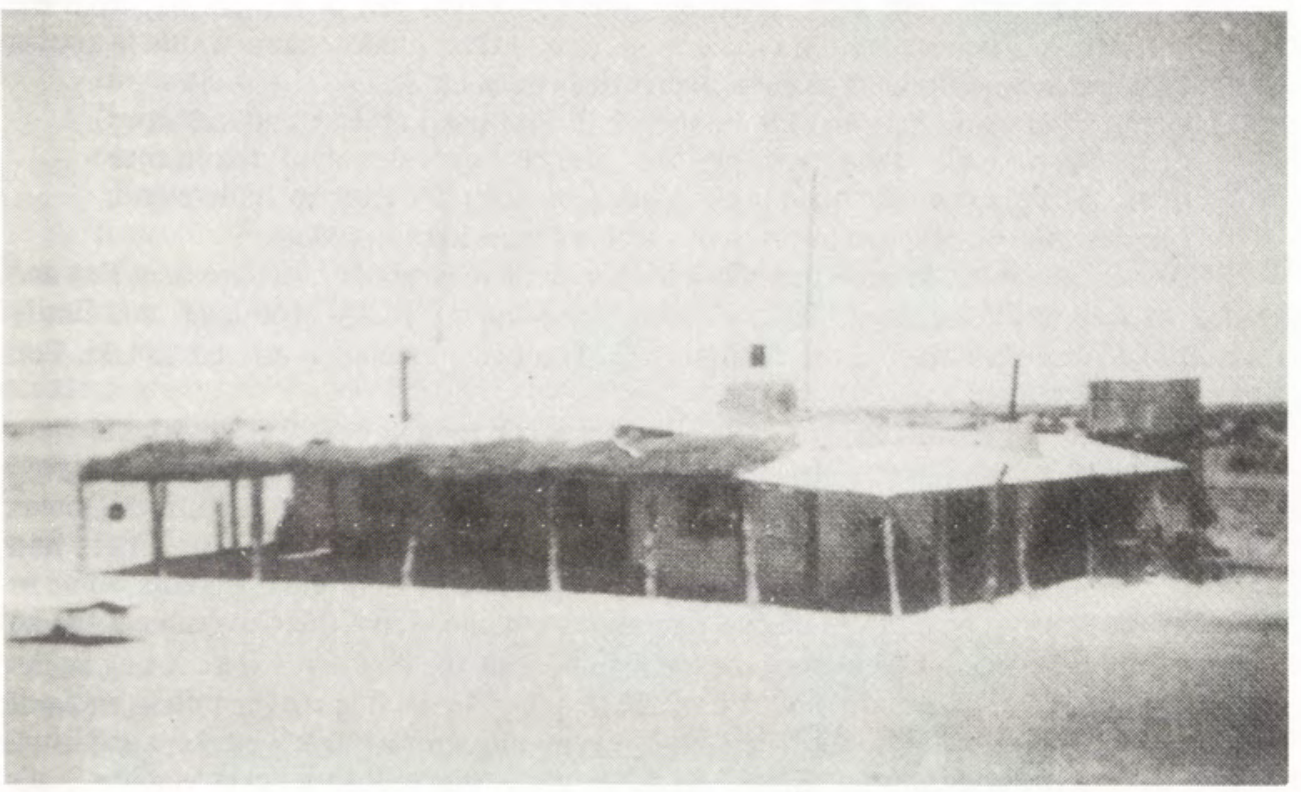

The original Muloorina homestead. Ben grew up in the nearby camp.

Photo: Lois Litchfield.

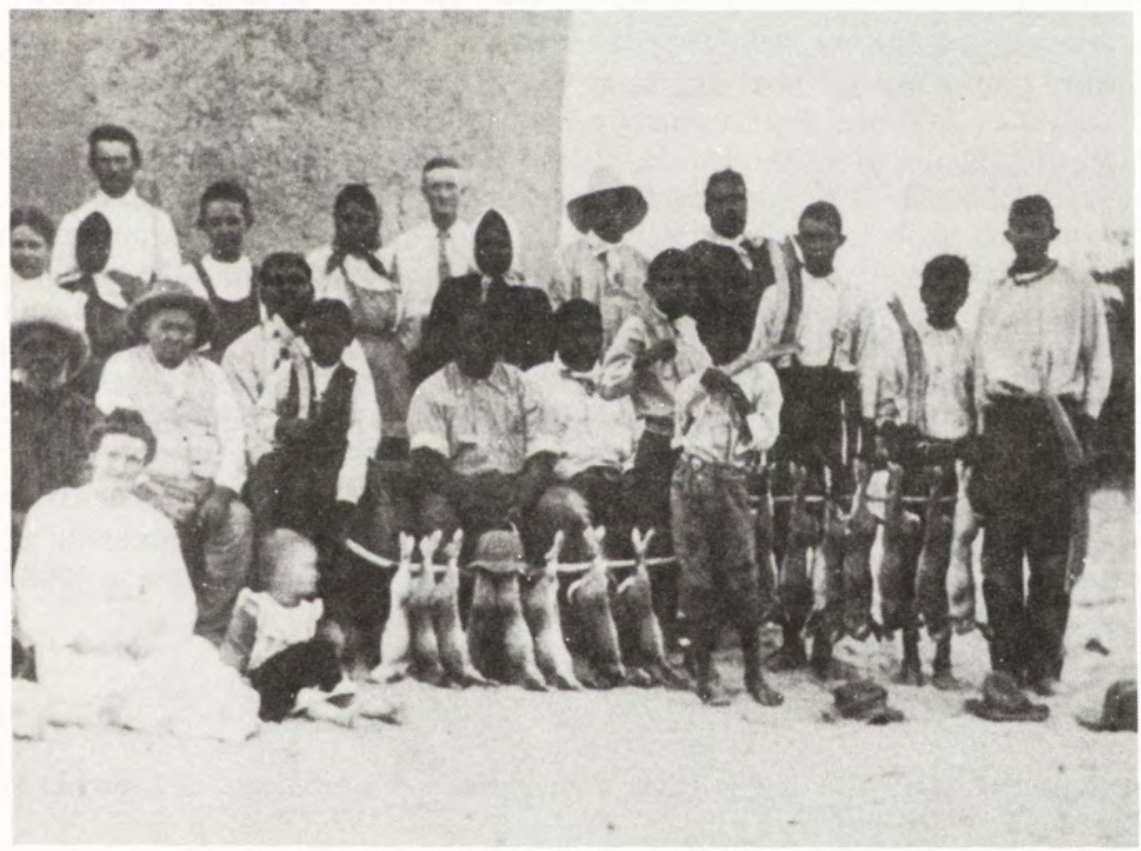

Group returned from rabbiting, Killalpaninna Mission, 1910. Ben Murray is standing at right. The boomerangs in his belt were used to kill rabbits, which had reached plague proportions. Photo: Frieda Bognor, 1910. PRG 509 Mortlock Library. 


\section{ABORIGINAL HISTORY 1988 12:2}

over the Peachawarrina and the Cannatulkaninna block (i.e. part of Muloorina) from the Bosworth family. Their struggle was as grim as that of their predecessors. Little is known about this anomalous pair, George Farwell describes them as:

Count Charles de Peri and his brother, Bill [Baptiste]...men of adventurous disposition, well-to-do, possibly the French equivalents of remittance men...A big excitable man, with explosive talk, difficult to understand, Charley always travelled about with a team of huge kangaroo dogs. 25

Ben was camped at Marree in 1906 with his mother, stepfather, his brothers Em and George as well as his 'cousins' Jimmy Russell Wangamirri "Many Mornings' and Emily Russell Mithanta 'Shining in the Sunlight'. ${ }^{26}$ The two Frenchmen arrived to take Ben away to work for them.

The Murray boys worked for two shillings a week for the next year or so and were badly treated by the de Pierres (see text below). This was not an isolated instance; an even more extreme case of exploitation occurred in the following decade at Minnie Downs station, further up the Birdsville Track. Here the two German brothers, Louis and Nathaniel van Loon Reese exploited the labour of a number of Aboriginal workers, some as young as the Murray boys, in exchange for rations obtained from the Government for no cost. $^{27}$ It may be that in the eyes of the local authorities the de Pierres were acting as the boys' guardians. Legally this would have been possible as Ben's own father was not prepared to take responsibility for him. In any event, the Murray boys were kept as virtual slaves, working from dawn to dark on a property which was probably never viable. Ben's brother Ern later recalled that the de Pierre brothers barely made a living despite their apparent capital:

[They] usually had about 1000 or 1500 sheep. They used to shear them in a brush shed. In flood times there was water everywhere...but in dry years they depended on this one well. They never seemed to trust anyone, and used to carry a lot of money about with them. ${ }^{28}$

In 1907 the elder de Pierre, Baptiste, inherited money from relatives in France and returned home, leaving Charles to run the station. Ben's job mainly involved fencing, and working with horses (about 75 were kept by the Frenchmen), but as a boy of sixteen he was probably not yet skilled, nor strong enough, to break them in. For this purpose the de Pierres employed an Aboriginal (Ngamini) man named Walter from the neighbouring Killalpaninna mission and Ben became his off-sider. Although Walter camped with Ben and his brothers, it seems that he was free to come and go between the station and the mission and to carry messages between the two places. By this time Ben's mother was living at Killalpaninna mission and although Lutheran discipline there was also rigorous, the contrast in their situations was obvious.

Walter told the boys that they should leave the de Pierres and come to the mission: "he said you better come to the mission, and learn, school". 29 After one unsuccessful attempt (see text below), Ben's real chance to escape from Wire Yard finally came in 1908 when

25 Farwell 1950:56.

26 Emily Russell was also called in Diyari Jirimirrini and is mentioned in a story in Murray and Austin 1981.

27 Jones (forthcoming).

28 Bonython 1971:170.

29 M-J, 2.2.88. 


\section{BEN MURRAY}

Charles de Pierre fell ill. 'Old Walter' arrived from the mission one morning to collect Ben and his brother Em. Ben recalled the event in July 1987:

He came over next morning. He said, 'Your mother wants you to shift.' 'No, [I said], I can't leave this bloke.' He was sick, he was laid up a bit. So he came in the night time, picked me up. Two of us there was, my brother too. .[We] travelled all night, get away from the Frenchman's place...run away from there to the mission...got there...we told Vogelsang, 'We run away. 30

Ben needn't have been so concerned about the Frenchman's health; Charles de Pierre turned up at the mission soon after, fully recovered and doubtless accompanied by his kangaroo dogs, to demand the return of his employees. Helen Jericho (née Vogelsang) recalled the occasion years later:

three ${ }^{31}$ half-caste lads of school age came to the Mission asking to be allowed to stay...Charlie arrived ${ }^{32}$...demanding their return. When Hermann [Vogelsang], who was in charge of the boys, would not comply with his demands, he became aggressive and threatened to fight my brother. However, the boys stayed there, so it seems that Charlie was in the wrong. ${ }^{33}$

The episode underlines the role of the mission as something of a sanctuary for Aboriginal people in the midst of what had become a threatening environment during the previous forty years. ${ }^{34}$ The Mission acquired the de Pierres' block in 1913; Charles lived in Marree for a time, and eventually became manager of the Lake Harry camel farm before its closure in 1918.35 .

The following account of the events at Wire Yard Station was given by Ben to Luise Hercus in September 1979.

\begin{tabular}{|c|c|}
\hline $\begin{array}{l}\text { 1. Arni } \\
\mathrm{We}\end{array}$ & $\begin{array}{l}\text { thangka-liparna. } \\
\text { stav-ANC }\end{array}$ \\
\hline
\end{tabular}

yuka-ngura ai!

come-CONT Eh!

2. MaRa-muluru 'Soft Claw', Muloorina, that is where they were staying.
3. MaRa-muluru-ruku
mani-thangka-ka,
MaRa-muluru-ruku
'claw-soft'-ALL take-stay-PAST 'claw-soft'-ALL

$\begin{array}{lll}\text { yuka-lhuku } & \text { nhanhangarda-ki } & \text { thangka-lhuku. } \\ \text { go-HIST } & \text { there-EMPH } & \text { stay-PURP }\end{array}$

30 M-J, 14.3.87; 2.2.88.

31 Ben's accounts, given to both Hercus and Jones, speak only of himself and Em. The third brother, George, is not mentioned.

32 In the text below Ben describes the two Frenchmen arriving at Killalpaninna to demand his return. However his account of events to Jones and the version recorded by Jericho indicates that only Charles was involved. Baptiste had returned to France by this time.

33 Jericho 1975:40.

34 Jones and Sutton 1986:37-8.

35 Litchfield 1983:93. 
4. Baptiste de Pierres and Charlie de Pierres,

pula yuka-ka.

two come-PAST

5. They had said: 'Ay, what about you fellows help us with the sheep?'

$\begin{array}{llll}\begin{array}{l}\text { 6. Kudnarri-nga. } \\ \text { flood-plain-LOC }\end{array} & \text { Harry Bosworth used to be a little } & \begin{array}{l}\text { minha-yi } \\ \text { what-VOC }\end{array} & \begin{array}{l}\text { punga } \\ \text { humpy }\end{array} \\ \begin{array}{ll}\text { karluka-naru } \\ \text { bull-mainly }\end{array} & \begin{array}{l}\text { minha-yi } \\ \text { what-VOC }\end{array} & \begin{array}{l}\text { minha-ru-thu } \\ \text { what-INST-EMPH }\end{array} & \begin{array}{l}\text { warlpa-thaka-yira } \\ \text { knock-hit-PUNC }\end{array}\end{array}$

patharra. That was the roof. But they used to put a tarpaulin over that. They lived there. Under a box-tree.

$\begin{array}{lll}\text { 7. Arni yuka-rna nhanhangarrda, } & \text { Lake Harry right through } \\ \text { we } & \text { go-PRES there }\end{array}$

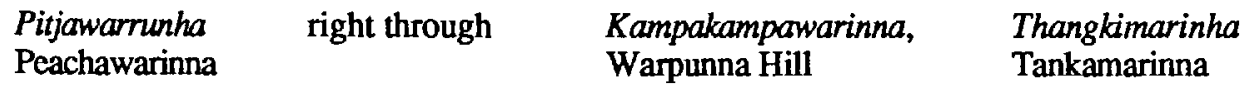

$\begin{array}{lll}\text { kaRu-kuta } & \text { yuka-ngura, } & \text { tharka-yiwa-rna. } \\ \text { there-ALL } & \text { go-CONT } & \text { stop-TR-PRES }\end{array}$

$\begin{array}{cccclll}\text { 8. Ay, intjali } & \text { kari? } & \text { Ipi-ipi } & \text { kari-ri } & \text { thangki-ra. } & \text { Oh! } \\ \text { Eh } & \text { where } & \text { they? } & \text { Sheep } & \text { they-ERG } & \text { tend-PUNC } & \text { oh }\end{array}$

Pirrka-purru-ru. He was an Arabana man married to a Thirrari woman from Muloorina. Pirrka-purtu -ERG

$\begin{array}{llll}\text { pula } & \text { nhupa-maRa } & \text { ipi-ipi } & \text { thangki-ngura. } \\ \text { two } & \text { spouse-having } & \text { sheep } & \text { tend-CONT }\end{array}$

\begin{tabular}{|c|c|c|}
\hline $\begin{array}{l}\text { 9. Athata-kunha } \\
\text { Grandfather-GEN }\end{array}$ & $\begin{array}{l}\text { waru-nganha. } \\
\text { old-from. }\end{array}$ & $\begin{array}{l}\text { Uka-thu } \\
\text { he-EMPH }\end{array}$ \\
\hline
\end{tabular}

$\begin{array}{lllll}\text { Mayi Withiyara } & \text { kari } & \text { nharla-nha? } & \text { Lhuka inkunha? } \\ \text { well! how } & \text { they } & \text { people-EMPH? mother yours? }\end{array}$
10. Mayi
well
kakari
these
thadna-rnda
leave-PRES
Marri-nga-li'.
Marree-LOC-EMPH
11. Ah,
unhanha
you-ACC
nguyu
kari-ri
one
they-ERG
mani-thika-rna?
take-return-PRES
12. $K o$.

Kari ngataru yuka-nha.'
They behind go-NP
13. Ko. Nhanhangarda
arniri we all
thangka-lhuku, sit-PURP
parn
bream
ngadla-nga, kutha plenty-LOC, water 


\section{BEN MURRAY}

$\begin{array}{lllllll}\text { ngadla-nga, } & \text { mayi, } & \text { kathi } & \text { njurdu } & \text { pirda-rma. } & \text { Kari-ri } & \text { rapiti } \\ \text { plenty-LOC, flour, } & \text { meat } & \text { also } & \text { kill-IMP } & \text { they-ERG } & \text { rabbit }\end{array}$

kapirri tharni-ka.

goanna eat-PAST

$\begin{array}{lllll}\text { 14. I don't know } & \begin{array}{l}\text { minha } \\ \text { what }\end{array} & \begin{array}{l}\text { kultji } \\ \text { money }\end{array} & \begin{array}{l}\text { kari-nha } \\ \text { they-ACC }\end{array} & \begin{array}{l}\text { ngunhi-ka, } \\ \text { give-PAST }\end{array}\end{array}$

might be only five bob a week.

15. Jimmy Wangamirri and Emily came later. They had nothing to do with the Frenchmen, they were only living on the Government ration. Just me and later also Ern were supposed to be working on their property.

$\begin{array}{cllll}\begin{array}{c}\text { 16. Antha } \\ \text { I }\end{array} & \begin{array}{l}\text { kanhangarda } \\ \text { there }\end{array} & \text { thangka-ka } & \text { pula-inta, } & \text { nhantu-nga } \\ \text { sit-PAST } & \text { two-DAT } & \text { horse-LOC }\end{array}$

$\begin{array}{lllll}\text { wanpa-rda, } & \text { go right round } & \begin{array}{l}\text { nhantu } \\ \text { horse }\end{array} & \begin{array}{l}\text { mani-lhiku, } \\ \text { get-PURP }\end{array} & \begin{array}{l}\text { pudluka } \\ \text { bullock }\end{array}\end{array}$

$\begin{array}{lllll}\text { padni } & \text { thadlu } & \text { nhantu } & \text { ya } & \text { ipi-ipi } \\ \text { nothing } & \text { only } & \text { horse } & \text { and } & \text { sheep }\end{array}$

Two bob (a week) they gave me, that was my pay!

$\begin{array}{lllll}\begin{array}{l}\text { 17. Karla-nga } \\ \text { creek-LOC }\end{array} & \begin{array}{l}\text { kutha } \\ \text { water }\end{array} & \begin{array}{l}\text { ngurku. } \\ \text { good }\end{array} & \begin{array}{l}\text { Thalthu witji-ka. } \\ \text { salty }\end{array} & \begin{array}{l}\text { Arni irtjirtji } \\ \text { become-PAST } \\ \text { we soakage }\end{array} \\ \begin{array}{l}\text { paka-lhuku } \\ \text { dig-HIST }\end{array} & \begin{array}{l}\text { kanhangarda } \\ \text { there }\end{array} & \begin{array}{l}\text { kutha } \\ \text { water }\end{array} & \begin{array}{l}\text { mani-rnda-lhuku. } \\ \text { get-SP-HIST }\end{array}\end{array}$

18. The old man (Pirrka-purru ) said: 'Why don't you bring a trough here, and a bucket! for the sheep. You know how to work that one?' 'I know how to use a bucket!' I thought he was going to give me a pump, chain-pump or windlass!

\section{Pakiti-ri ngarritii-lhiku bucket-INST descend-HIST}

20. We ran away, Wangamirri and me, Wangamirri had been staying there by that time. We travelled all night. 36

21. If you did anything wrong they would tie you up and belt you with a rope! Finally an old man came along, an old Aboriginal man. By the mail he came, the mail had to cross there to get to Killalpaninna.

36 Apparently they were caught and Ben was taken back again to work with the Frenchmen. He was with them for two years. 


$\begin{array}{lllll}\text { 22. Arla } & \text { Karra-lhuku } & \text { pirda-lhuku. } & \text { Thadla-ra } & \text { yuka-rna } \\ \text { enough } & \text { tie up-PURP } & \text { beat-PURP. } & \text { fear-CAUS } & \text { go IMP }\end{array}$

Kirla-wilpa-ruku.

Killalpaninna-ALL

23. We went to Killalpaninna to Hermann Vogelsang. He was schoolteacher at the mission. I told him all about it. The two Frenchmen came 'We want them boys back!' 'You can't take'em!' Vogelsang said. The Frenchmen were there, stockwhip in hand.

$\begin{array}{cl}\text { 24. Arluwa-pula-nha mani-lhiku, pirda-lhuku, Ngatu-thakali uka-inta } \\ \text { boy-two-ACC } & \text { take-PURP beat-PURP Ngatu-thakali he-DAT }\end{array}$

irlinha yanta, ayi!

thus speak, eh!

\begin{tabular}{|c|c|}
\hline $\begin{array}{l}\text { 26. Kutha-nga } \\
\text { water-LOC }\end{array}$ & $\begin{array}{l}\text { widna-lhuku } \\
\text { put down-PURP }\end{array}$ \\
\hline
\end{tabular}

A rope gets nasty when it is wet!
27. Thadla-ma-lhuku
kari-ri. fear-make-HIST
they-ERG

28. After a while I, just I alone, went back to the remaining Frenchman, after his brother had gone. 'Ah you know all that country,' he said, 'show me the boundary!' 'You can see it on a map!' I said.

29. 'Where are you going to get water?' he asked me. There is a trough there'. 'We can't drink that!' 'Of course you can, it is good water. It is yuwu-kunha, soakage water, which Aboriginal people used to drink.'

30. Everything was different then.

\section{Translation}

1. We were living there (at Marree). Well, the two Frenchmen came along.

2. MaRa-muluru 'Soft Claw', Muloorina, that is where they were staying.

3. They came to take me away to Muloorina. So off we went to stay at Muloorina.

4. The two of them had come, Baptiste and Charlie de Pierres.

5. They had said: 'Ai, what about you fellows help us with the sheep?'

6. On the floodplain of the lower Cooper Harry Bosworth had a little sort of humpy, with bullhide nailed onto box-tree uprights. That was the roof. But they used to put a tarpaulin over that. They lived there.

7. We went there, we went to Lake Harry and right through to Peachawarinna and right through to Kampakampawarina (Warpunna Hill), and then we went on to Lake Tankamarinna and stopped there. 


\section{BEN MURRAY}

8. The de Pierres asked: 'Where are they, the people who are supposed to be looking after the sheep?' It was Pirrka-purru who was looking after the sheep, him and his wife. He was an Arabana man married to a Thirrari woman from Muloorina.

9. He had known my grandfather for a long time. He said to me: 'Well, how are the Aboriginal people (at Marree), and how is your mother?'

10. 'I left them behind in Marree,' I said.

11.'So these two brought you here all on your own?'

12. 'The others might follow me later.'

13. He said: 'We could all stay here, where there is plenty of fish, plenty of water, flour, and we also get to kill sheep for meat.' But really they lived on rabbits and goannas.

14. I don't know how much money the Frenchman gave them, it might have been only five bob a week.

15. Jimmy Wangamirri and Emily came later. They had nothing to do with the Frenchmen, they were only living on the Government ration. Just me and later also Em were supposed to be working on their property.

16. I stayed there with the two of them riding about everywhere to muster horses, they didn't have cattle, only horses and sheep. Two bob (a week) they gave me, that was my pay!

17. There was good water in the creek, but it turned salty. So we dug a soakage there to get good water.

18. The old man (Pirrka-purru ) said: 'Why don't you bring a trough here, and a bucket! for the sheep. You know how to work that one?' 'I know how to use a bucket!' I thought he was going to give me a pump, chain-pump or windlass!

19. So we had to get down (into the soakage) with a bucket.

20. We ran away, Wangamirri and me, Wangamirri had been staying there by that time. We travelled all night.

21. If you did anything wrong they would tie you up and belt you with a rope! Finally an old man came along, an old Aboriginal man. By the mail he came, the mail had to cross there to get to Killalpaninna.

22. He was a Ngamini but he also talked Diyari. He came in the middle of the night and he said: 'Your old uncle (Ngatu-thakali ) is still alive! He says you have been tied up and beaten for long enough!' So we escaped with him, very frightened, to Killalpaninna.

23. We went to Killalpaninna to Hermann Vogelsang. He was schoolteacher at the mission. I told him all about it. The two Frenchmen came 'We want them boys back!' 'You can't take'm!' Vogelsang said. The Frenchmen were there, stockwhip in hand. One of my relations, he said 'Ay! we don't want those two boys to be taken away and flogged!' That is how old Ngatu-thakali spoke.

25. Vogelsang said: 'I shall keep these two boys and give them schooling.' He spoke in Diyari. He tried to teach us the ABC and all that. We stayed there. The Frenchmen had wanted to use sticks and a rope.

26. They used to soak a rope in water and then beat us with it. A rope gets nasty when it is wet!

27. (The missionaries too) they frightened us, we couldn't help it, we learnt to read and write!

28. After a while I, just I alone, went back to the remaining Frenchman, after his brother had gone. 'Ah you know all that country,' he said, 'show me the boundary!' 'You can see it on a map!' I said.

29. 'Where are you going to get water?' he asked me. 'There is a trough there'. 'We can't drink that!' 'Of course you can, it is good water. It is yuwu-kunha, soakage water, which Aboriginal people used to drink.' 
30. Everything was different then.

\section{Killalpaninna Mission Years: 1908-1914}

Killalpaninna mission became Ben's home for the next seven years, until he left reluctantly at the age of twenty-three. For most of this time he worked as hard as he ever had, but for the first few months at least, Ben was exposed to an entirely new experience - a European education. For the Lutheran missionaries at Killalpaninna the classroom held most hope and promise in a Christian endeavour which Pastor Johann Reuther had described despondently as a 'stony field of labour'. 37 Helen Jericho's assumption that the boys had fled from Wire Yard station in order to gain an education is perhaps an indication of the prominence which the school had as an active force of social change throughout the region. Certainly, the teachers at Killalpaninna achieved a high degree of success in training numbers of Aboriginal (and European) children in literacy in both Diyari and English. ${ }^{38}$ Ben's ability to read and write in these languages later gave him a decided advantage in moving between the two cultures.

This was Ben's first full encounter with both the Christian religion and the Diyari language

we start school there, in the Diyari language, not too much English...

Diyari...I had to learn it there. Bible and all that you know, they give you

Bible...religious turn-out. ${ }^{39}$

Since its establishment in 1866 in the heart of Diyari country on the lower Cooper Creek, the Lutheran Mission had attracted several other neighbouring language groups, including Ngamini, Thirrari and Wangkangurru. 40 Diyari remained the 'official' language at the mission: the first Diyari texts were published by Johann Flierl in 1880 and a Diyari New Testament was published in 1897.41 Ben kept a copy of this Bible with him until his papers and belongings were destroyed by fire in 1979 .

Ben came to Killalpaninna just a few months before Pastor W. Riedel arrived as replacement missionary for Pastor Johann Reuther, who had retired from mission life in 1906. Pastor F. Bogner ${ }^{42}$ was in charge of the mission in the interim, supported by the lay helper and original mission pioneer, Hermann Heinrich Vogelsang. Vogelsang's son Augustus Hermann would have been Ben's teacher and classes were held each moming from 9.00am to $12.00 \mathrm{pm}$.

Ben's skills as a horseman were soon noted and by the time that he had the rudiments of an education he was working again, initially as an odd-job worker around the mission and later as a stockman. One of his first jobs was to help in controlling the rabbit plague which threatened the mission following the Cooper flood of 1906. Shortly after Riedel's

37 Scherer 1979:13.

38 See Austin 1987 for examples and analysis of Diyari literacy at Killalpaninna during this period.

39 M-J, 14.3.87. Ben probably heard Diyari spoken at Muloorina and Marree among the old people, though it is not clear if he learned to speak it himself before coming to the mission. In the following comment, he seems to use the term 'learn' in the sense of 'study'.

Jones and Sutton 1986:32ff.

41 Reuther and Strehlow 1897.

42 F. Bogner was the missionary who came to replace Siebert in 1902. He and Jaensch ultimately took over the lease of the mission (see below). 


\section{BEN MURRAY}

arrival the mission purchased its first camel team to carry supplies north from Marree. Ben was taught the camel work on the mission by an Afghan man named Akbar Khan (see Text I below) and a part-Aboriginal man, Tom Davies, and after his departure he was assisted by Jack Hanness, a Diyari man. Ben also learnt from Afghan men in Marree - including his father and Fasi Khan. In the course of this work Ben became familiar with the Afghans' ways and built up a rich store of tales about them (see Text $\mathrm{H}$ below).

By 1912 Ben was a partner in the 'camel business', working with Jack Hanness as a regular partner on the four day trip south to Marree and by 1914 he had become the boss. It was a tough job, managing a string of thirty or forty camels and tying and untying heavy loads. A typical load per camel might consist of:

two bales of wool, four bags of flour, six bags of sugar, or cases of potatoes carried two each side bound together with fencing wire.

Although the mission never again reached the levels of wool production attained during the 1890 s, there were nevertheless large loads to be carted south after the shearing was completed at the Etadunna woolshed. Ben recalls that on these occasions he loaded up to seventy camels with bales of wool - $400 \mathrm{cwt}$ on a young camel and $600 \mathrm{cwt}$ on a large bull camel. Despite the heavy work Ben enjoyed the 'camel business', preferring it to all of his later jobs. He knew each camel by name: Kangaroo was his own riding camel, and others were Jim, Charlie, Susie, Soona, Nancy, Fanny and Nora. If any gave him trouble he just 'worked them', giving them a heavier load until they settled again: 'quiet them down with six hundredweight'.

Ben would ride at the front, leading the other camels. Another man would ride in the middle and one at the rear. If they had made a late start they might stop the first night at Blazes Well, a few kilometres south of Etadunna. There was a well and an eating house there, but Ben and his men would cook their own food. Otherwise Ben would travel through to Dulkaninna where the men would water the camels and travel on to camp at the Big Sandhill (Dakupirna) just to the south where there was a soakage for drinking water. On the next night they would water the camels and camp at Clayton Creek and the following evening they would reach Lake Harry with its constant supply of bore water. They would water the camels there, taking them in the evening for a drink before hobbling them at their camp for the night, away from the water. By the next evening Ben and the team reached Well Creek, about fifteen kilometres out of Marree, or Frome Creek on the edge of the town itself if they had made good time. This was their last camp before entering Marree in the morning. 43

Once in Marree, there was no rest for Ben. After unloading the camels at the railway station he visited the storekeeper, Mr Manfield, and bought two bags of chaff to feed the camels in the trucking yard before loading the bales of wool into the rail trucks. Once that was finished his next task was to load the mission supplies and collect the mail for the return journey to Killalpaninna. For all this work Ben received five shillings from the storekeeper who would be reimbursed by the mission. This amount was equivalent to an Aboriginal shepherd's wage and was half the cost of a pair of moleskin trousers. It was, as Ben considered at the time, far too little:

It got too much for me then. I said, 'I want enough pay - give me $7 / 6$ a week'. Yeah, they give me $7 / 6$ a week after that, after I stuck up for it. I said too much hard work. I got to make the saddles, saddles for the camel. I got 
to leam [that], I got to go and see Afghans. They learn me, how to make a saddle, everything! And I get five bob when I get to Marree! 44

Ben had friends in Marree and got on well with the publican, Tom Dooley and his wife, a 'good woman' who gave Ben a meal, charged to the mission (see Text F). However, as Text $\mathrm{G}$ shows, Ben knew where to draw the line in his relations with the town people.

\section{TEXT F 'A Parcel for Mr Aiston'}

Like most people in the area, Ben knew and liked the police-trooper George Aiston, 45 later famous for his work with Aboriginal people, particularly as co-author of Home and Aiston 1924. Ben often visited Aiston, who lived at Mungerannie and after 1912 at Mulka on the Birdsville Track. ${ }^{46}$ Aiston's closest friend on the Track was a Diyari man, Gottlieb Merrick. They enjoyed an occasional drink of whisky, and one time, when Ben came by, they were running short of supplies. Because of the regulations governing the sale of alcohol it was not easy for Ben to help out, as he explained to Luise Hercus in February 1976.

\section{Pula tharka-rnda \\ Two stand-PRES \\ kanhangarda \\ there \\ Malka-nga kudnakardi \\ Mulka-LOC guts \\ thapu. \\ huge.}

2. 'Come on in!' Mr Aiston would say (to any visitor). Gottlieb Merrick used to drink a fair bit, and that is why he used to go over so that he could get what he wanted from $\mathrm{Mr}$ Aiston. They were whisky drinkers!

3. How long will you be away?' Mr Aiston asked me. 'I am going with a riding camel.' 'Can you bring me a parcel?' 'All right.' So Mr Aiston wrote a letter on a piece of paper.

4. 'I'll go and have a meal there (at the pub). We can't make a fire outside, no wood there, so we have got to go to the pub. The Mission has got to pay for this.'

5. So I did go in and I said to Mrs Dooley - I didn't walk in the bar, but I went over to where Mrs Dooley usually sits. And I showed it (the letter) to her. And she said: From Mr Aiston, eh! Where are you going to go?' 'I am going to the store. I'll come round tonight.'

\begin{tabular}{|c|c|c|c|c|c|c|}
\hline $\begin{array}{l}\text { 6. Antha } \\
\text { I }\end{array}$ & $\begin{array}{l}\text { wanti-nta,s } \\
\text { wait-REFL }\end{array}$ & $\begin{array}{l}\text { tora-n } \\
\text { store- }\end{array}$ & & $\begin{array}{l}\text { Uka } \\
\text { she }\end{array}$ & $\begin{array}{l}\text { anthirda } \\
\text { me-DAT }\end{array}$ & $\begin{array}{l}\text { yani-rnda } \\
\text { say-PRES }\end{array}$ \\
\hline $\begin{array}{l}\text { antha } \\
\text { I }\end{array}$ & $\begin{array}{l}\text { thika-rnda } \\
\text { return-PRES }\end{array}$ & $\begin{array}{l}\text { yani- } \\
\text { speak }\end{array}$ & & & $\begin{array}{l}\text {-thika-lhw } \\
\text { umn-PURP }\end{array}$ & \\
\hline $\begin{array}{l}\text { 7. } A i \text {, } \\
\text { Eh, }\end{array}$ & $\begin{array}{l}\text { wanga-wanga } \\
\text { early morning }\end{array}$ & $\begin{array}{l}\text { antili } \\
\text { first }\end{array}$ & $\begin{array}{l}\text { ma } \\
\text { ge }\end{array}$ & & $\begin{array}{l}\text { Yuta } \\
\text { now }\end{array}$ & $\begin{array}{l}\text { nhakari } \\
\text { these people }\end{array}$ \\
\hline $\begin{array}{l}\text { 8. Uta } \\
\text { now }\end{array}$ & $\begin{array}{l}\text { manta-yiwa-lh } \\
\text { get-TR-HIST- }\end{array}$ & thi, & $\begin{array}{l}\text { mo } \\
\text { foo }\end{array}$ & zayi & $\begin{array}{l}\text { kuljur } \\
\text { chaff }\end{array}$ & $\begin{array}{l}\text { kamulu -ku. } \\
\text { camel-DAT }\end{array}$ \\
\hline
\end{tabular}

44 M-J, 31.7.87.

45 See photograph in Jones and Sutton 1986:54.

46 Maddock 1.986:44. 


\section{BEN MURRAY}

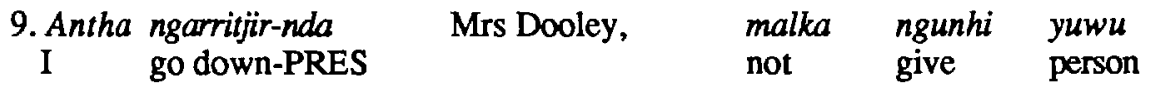

nguru tharda-ru!

other send

'Intjaliri?'

'Where?'

Yakita-ruku.

yard-ALL.

10. Anha

nhanhi-thiya kari-ri, mathapurda

kari-ri,

me

see-LEST

they-ERG old man

they-ERG

mathapurda

kari madla

arla, ngurra yani-li, yulja

old man

they bad

very hard

talk-HAB police

nhanhi-kuara.

see-PLUP

11. Uljurla-thu yani-rnda, woman-EMPH say-PRES

'Eh, that has got nothing to do with it,

those policemen know you!'

12. 'Yes but that old timer 47 might put me away just because I am carrying something!' 'He can't do anything, you are taking this parcel for so and so, addressed to him.'

$\begin{array}{cllll}\text { 13. Arla } & \text { ngurku. } & \text { Ngunjimayi } & \text { yuwu } & \text { nguru anthirda iki! } \\ \text { all right } & \text { good. } & \text { Please } & \text { man } & \text { other }\end{array}$

14.Antha wanti-nta kanhangarda. Arlali uka-ru iki-ra.

I wait-PRES there. finally he-ERG shift-PUNC

15. Well he came round there with the parcel.

$\begin{array}{ccll}\text { 16. Kari-ri } & \text { nhanhi-ka } & \text { wka-ru } & \text { wanpa-iki-ngura-thu. } \\ \text { they-ERG } & \text { see-PAST } & \text { he-ERG } & \text { hold-carry-CONT-EMPH }\end{array}$

$\begin{array}{lllll}\text { Saddle athu } & \begin{array}{l}\text { kanhangarda } \\ \text { there }\end{array} & \begin{array}{l}\text { kudni, } \\ \text { putdle }\end{array} & \text { yakuta-nga } & \text { widna-ngura } \\ \text { bag-LOC } & \text { hide-CONT }\end{array}$

antha thika-ka Thidna-kurdaninha, Blaze's Well.

I return 'Foot Put Down'

47 This probably refers to the senior policeman. 
17. (When I got to Mulka) old man Mr Aiston, they called him 'Poddie', he said as usual: 'Come over and have a chat!'

$\begin{array}{lll}\begin{array}{l}\text { 18. Kudnardi-thapu, } \\ \text { guts-huge }\end{array} & a i & \text { kawulata, old Gottlieb there too, } \\ \text { eh } & \text { those two }\end{array}$

\begin{tabular}{|c|c|c|}
\hline $\begin{array}{l}\text { kudnardi-pula } \\
\text { guts-two }\end{array}$ & $\begin{array}{l}\text { wanka-rda-ki! } \\
\text { rise-PRES-EMPH }\end{array}$ & old Gottlieb. \\
\hline
\end{tabular}

$\begin{array}{lllll}\text { 19. Pula } & \text { yuka-rna, } & \text { kupula } & \text { thiki-lhiku } & \text { ngura-nga } \\ \text { two } & \text { go-IMP } & \text { drink } & \text { takeback-PURP } & \text { camp-LOC }\end{array}$

thangki-lhiku.

keep-PURP

\begin{tabular}{ccccc}
$\begin{array}{c}\text { 20. Uka } \\
\text { she }\end{array}$ & $\begin{array}{l}\text { nhupa-nha } \\
\text { wife }\end{array}$ & $\begin{array}{l}\text { netting-nga } \\
\text { netting-LOC }\end{array}$ & \multicolumn{2}{c}{$\begin{array}{l}\text { waya-nangka-ngura, } \\
\text { work-CONT S-CONT }\end{array}$} \\
$\begin{array}{c}\text { nhantu-nga } \\
\text { horse-LOC }\end{array}$ & $\begin{array}{l}\text { uka } \\
\text { she }\end{array}$ & $\begin{array}{l}\text { yuka-ngura, } \\
\text { go-CONT }\end{array}$ & $\begin{array}{l}\text { nhantu } \\
\text { horse }\end{array}$ & $\begin{array}{l}\text { manta-thika-lhuku.. } \\
\text { take-return-PURP }\end{array}$
\end{tabular}

He (Gottlieb) couldn't even stand.

$\begin{array}{lllll}\begin{array}{l}\text { 21. Uljurla-ru } \\ \text { woman-ERG }\end{array} & \begin{array}{l}\text { njinta } \\ \text { tree }\end{array} & \begin{array}{l}\text { thaka-rna, } \\ \text { cut-IMP }\end{array} & \begin{array}{l}\text { paka-rma, } \\ \text { dig-IMP }\end{array} & \begin{array}{l}\text { patcha-ma-rna. } \\ \text { patch-make-IMP }\end{array}\end{array}$

22. It was she who did everything. Even in midsummer. She might put in a patch a foot long. He might help her tie it on. He could do that sitting down.

\section{Transtation}

1. Those two enormously fat men were at Mulka.

2. 'Come on in!' Mr Aiston would say (to any visitor). Gottlieb Merrick used to drink a fair bit, and that is why he used to go over so that he could get what he wanted from Mr Aiston. They were whisky drinkers!

3. 'How long will you be away?' Mr Aiston asked me. 'I am going with a riding camel.' 'Can you bring me a parcel?' 'All right.'

So Mr Aiston wrote a letter on a piece of paper.

4. 'I'll go and have a meal there (at the pub). We can't make a fire outside, no wood there, so we have got to go to the pub. The Mission has got to pay for this.'

5. So I did go in and I said to Mrs Dooley - I didn't walk in the bar, but I went over to where Mrs Dooley usually sits. And I showed it (the letter) to her. And she said: 'From Mr Aiston, eh! Where are you going to go?' 'I am going to the store. I'll come round tonight.'

6. 'Or I'd better just wait at the store.' She said, 'I'll come back and talk to you and I will get it ready,'

7. 'Well I might not pick it up till early tomorrow morning. There are all these people here!"

8. I went to get some food and some chaff for the camel. 


\section{BEN MURRAY}

9. I went back down to Mrs Dooley and I said: 'Please don't give it to me yourself, get another person to bring it to me.' 'Where?' she asked. 'To the yards' (I said).

10. 'Otherwise people might see me, some of the old people might. And some of those old fellows are really bad, they are hard at it talking (about others) all the time, and the police would get to know about it.'

11. The woman (Mrs Dooley) said, 'Eh, that has got nothing to do with it, those policemen know you!'

12. 'Yes but that old timer might put me away just because I am carrying something!' 'He can't do anything, you are taking this parcel for so and so, addressed to him.'

13. 'All right, will you please send some other man?'

14. I waited there (at the camel-yards). Finally he brought it on its way.

15. Well he came round there with the parcel.

16. They (no doubt) saw him holding and carrying (the parcel). I put it on the saddle, I hid it in the saddle-bag, and I went off (without stopping) to Blaze's Well, that is Thidnakurdinha, 'Where (the Sun Ancestor) put her foot down (in the soft mud)'.

17. (When I got to Mulka) old man Mr Aiston, they called him 'Poddie', he said as usual: 'Come over and have a chat!'

18. Those two with the huge stomachs - old Gottlieb was there too - oh how their stomachs protruded! (Specially) poor old Gottlieb!

19. The two of them came and took the drink back into the house and kept it there.

20. Gottlieb's wife 48 was working all the time on the netting fence, and she went round on a horse mustering the horses. He (Gottlieb) couldn't even stand.

21. It was the woman who cut trees, dug holes (for fence posts), and patched up the fence.

22. It was she who did everything. Even in midsummer. She might put in a patch a foot long. He might help her tie it on. He could do that sitting down.

\section{Text G 'Unloading at the Mission'}

Another delicate task for the mail-driver was to bring small quantities of Parachilna ochre from Marree for Aboriginal people at the Killalpaninna Mission. Ben had to resort to various devices to help with the ochre. This text, describing the part which Ben played in maintaining the traditional red ochre trading network, ${ }^{49}$ also demonstrates the way in which he operated between the cash economy of traders and missionaries and the traditional culture of his mother's people.

In the case of the red ochre trade, Ben was dealing with the 'wurley natives' who lived outside Killalpaninna itself as a result of a firm decision not to 'come in' to the mission except for their fortnightly rations. Ben later spoke disparagingly of this shifting, independent group, which was mostly composed of older people from a variety of language groups, but he was nevertheless related to several of them and would have had specific obligations towards these individuals at least.
1. Wangara
morning
arkapa
ngunhi-ka.
ochre
give-PAST

48 This was Frieda Merrick, who assisted Peter Austin with his Diyari studies. Ben caught up with Gottlieb and Frieda when he worked at Murnpeowie Station many years later (see below).

49

See Jones, Austin and Hercus (forthcoming). 


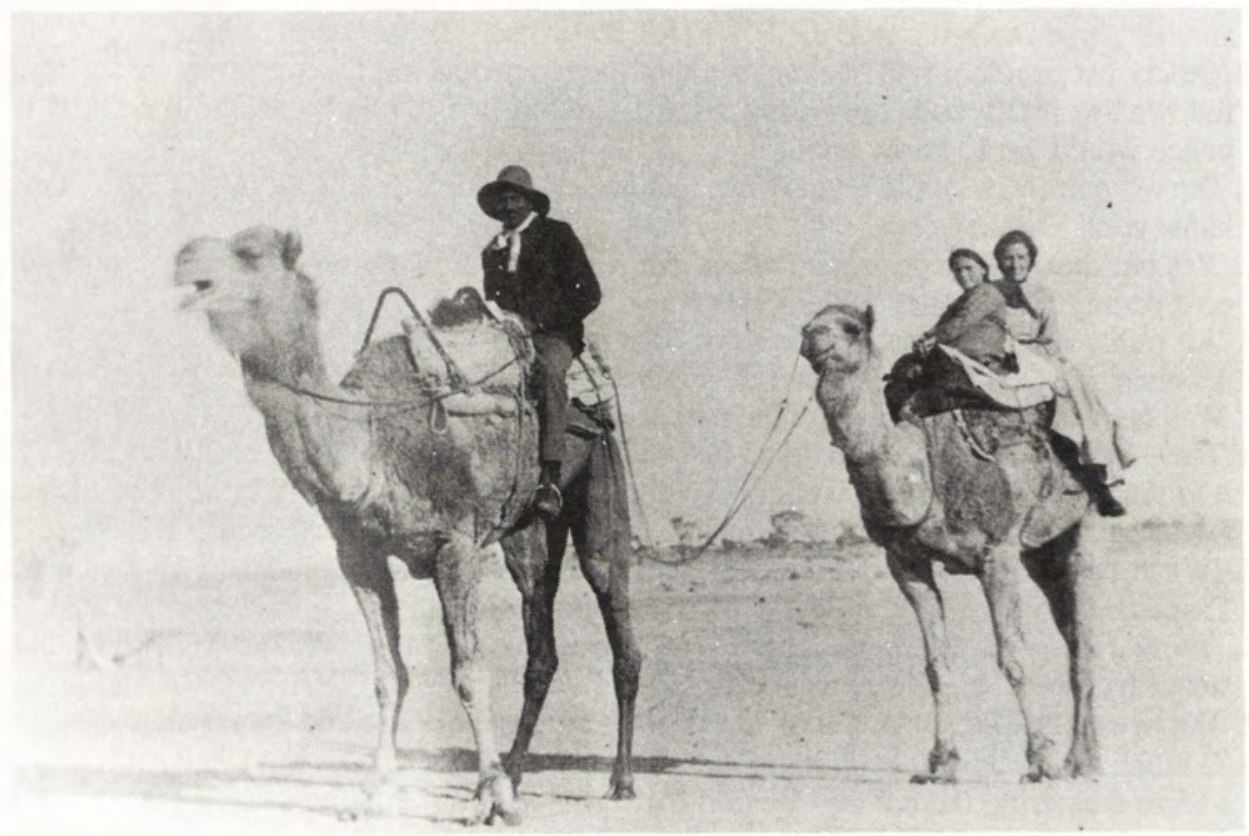

Ben Murray riding a favourite camel, 'Jim', c.1913. Mrs Ted Vogelsang and Helen Bognor are riding 'Charlie'.

Photo: Hermann Vogelsang, Lutheran Archives collection.

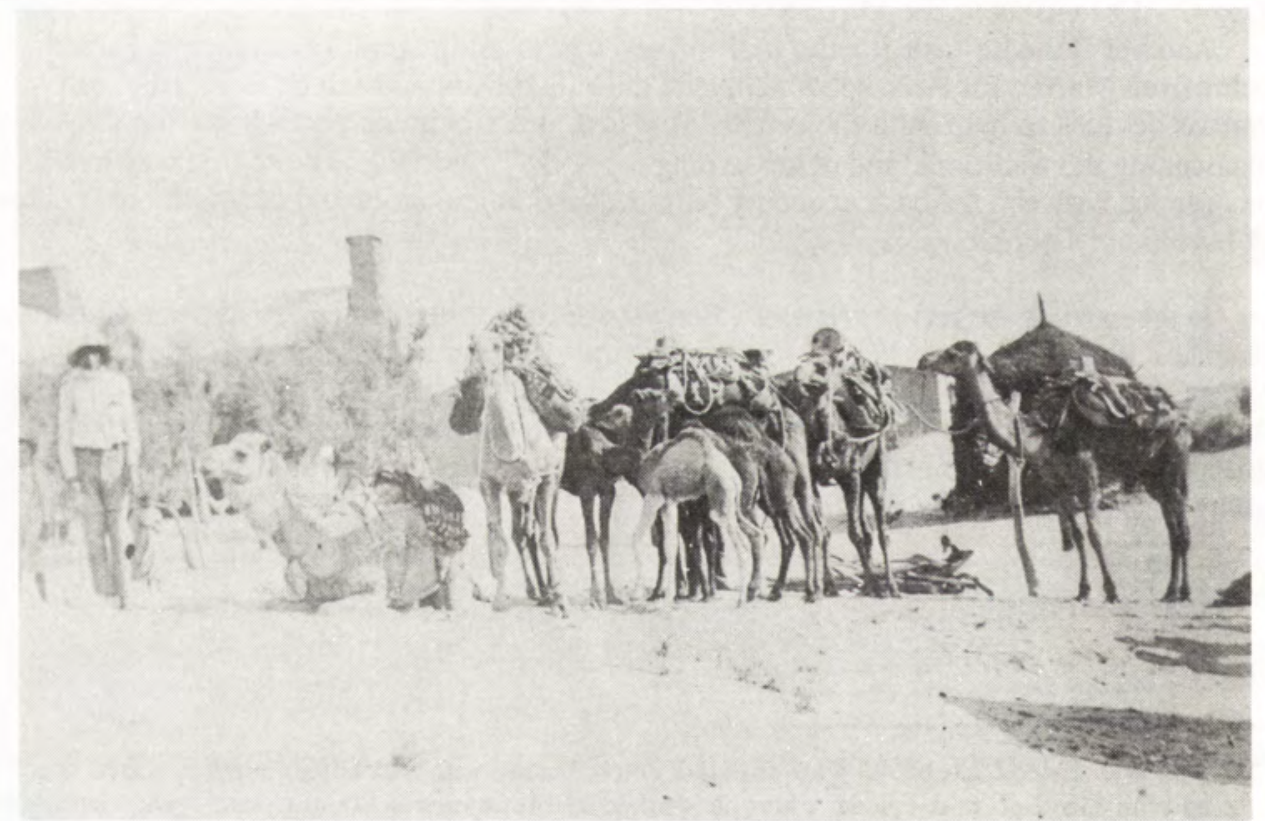

Ben Murray after unloading missions stores from camels at Killalpaninna, c.1913. Photo: Hermann Vogelsang, Lutheran Archives collection. 
go-HIST station-ALL

we went to put them in the store.

$\begin{array}{rll}10 \text { 'Mayi, } & \text { intja } & \text { arkapa-thu?' } \\ \text { 'Well, } & \text { where } & \text { ochre-EMPH }\end{array}$

$\begin{array}{cll}\begin{array}{c}\text { 11. Kanhangarda } \\ \text { That }\end{array} & \text { thadna-ka } & \text { Ngarlani-nga, } \\ & \text { leave-PAST } & \text { Ngarlani-LOC }\end{array}$

I didn't bring it here because Vogelsang mightn't like it!

\begin{tabular}{|c|c|c|c|c|c|}
\hline $\begin{array}{l}\text { Athu } \\
\text { I }\end{array}$ & \multicolumn{2}{|c|}{$\begin{array}{l}\text { ngurka-ra } \\
\text { know-PUNC }\end{array}$} & $\begin{array}{l}\text { antha } \\
\text { I }\end{array}$ & $\begin{array}{l}\text { thika-rna } \\
\text { return-IMP }\end{array}$ & \multirow[t]{2}{*}{$\begin{array}{l}\text { nhikinta-ruku } \\
\text { here-ALL }\end{array}$} \\
\hline $\begin{array}{l}\text { 12. Kari } \\
\text { They }\end{array}$ & \multicolumn{2}{|c|}{$\begin{array}{l}\text { anari } \\
\text { this way }\end{array}$} & $\begin{array}{l}\text { wanka-nha } \\
\text { approach-N }\end{array}$ & $\begin{array}{l}\text { tjarlpa } \\
\text { food }\end{array}$ & \\
\hline \multicolumn{3}{|c|}{$\begin{array}{l}\text { mani-rnda-thika-lhuku } \\
\text { take-SP-return-PURP }\end{array}$} & $\begin{array}{l}\text { untu } \\
\text { you }\end{array}$ & & \\
\hline $\begin{array}{l}\text { ngunhi-n } \\
\text { give-NP- }\end{array}$ & $\begin{array}{l}\text { ha-nga } \\
\text { LOC }\end{array}$ & $\begin{array}{l}\text { kari } \\
\text { they }\end{array}$ & $\begin{array}{l}\text { tjarlpa } \\
\text { food }\end{array}$ & $\begin{array}{l}\text { waya-rnda } \\
\text { wish-PRES }\end{array}$ & $\begin{array}{l}\text { thiki-lhiku } \\
\text { take back-PURP }\end{array}$ \\
\hline $\begin{array}{l}\text { mathapur } \\
\text { old man- }\end{array}$ & $\begin{array}{l}\text { da-ru } \\
\text { ERG }\end{array}$ & $\begin{array}{l}\text { awar } \\
\text { this }\end{array}$ & -ERG & $\begin{array}{l}\text { hanhi-lira. } \\
\text { ee-LEST }\end{array}$ & \\
\hline
\end{tabular}

\section{Translation}

1. They gave me the ochre in the morning (at Marree).

2. I gave it to the old man in the store: 'I'll put it in and store it up for you,' the storekeeper might say.

3. 'Let it stay there for another day!' (I would say). 'What for?'

4. 'Certain things are not easy, in the meantime you keep that (ochre).'

5. There was an Aboriginal man just travelling about, he could take the ochre for them. So I fixed him up with a riding camel.

6. (Ben apparently hid the ochre inside a flour bag). I put it (the flour-bag) on the saddle of the camel, so that it could be taken on ahead and then I set off straight away to Ngarlangarlani (with the rest of the load for the Mission).

7. 'Where is that old man?' 'Ah' said an Arabana man (speaking in Arabana) 'that old man went out hunting just a moment ago.'

8. 'I hid the ochre in this flour-bag right here' (where the old man had put it). I showed it to him (and left it with him).

9. I went on to the Mission and I asked for Dipa. We unloaded (the bags) and then we went to put them in the store.

10. 'Well, where is the ochre?' he asked.

11. 'I left it at Ngarlani, I didn't bring it here because Vogelsang mightn't like it! and I knew that I myself had to come right back to here.

12. People will come up to us to pick up their food, and if you gave it to them here while they are taking their food back (to their camps) the old fellow might notice.' 


\section{BEN MURRAY}

13. Old Bogner, well he didn't like it, you know he saw where I had cut the comer of the flour-bag (to put the ochre in). 'You shouldn't do that!' 'Well,' I said, 'you won't let me starve, not you or anybody else!'

Text H 'Jealous Afghans'

Recorded by Peter Austin at Farina 28th November 1975 (fieldtape D34b, transcription Book III pp132-37)

Ben had many stories about the ways of the Afghans with whom he worked. ${ }^{52}$ On one occasion he saw their attitudes to women lead to attempted murder. 53

\begin{tabular}{|c|c|c|c|c|}
\hline $\begin{array}{l}\text { 1. Mathapurda } 54 \\
\text { old man }\end{array}$ & Sarrawa & $\begin{array}{l}\text { nhulu } \\
\text { he-ERG }\end{array}$ & $\begin{array}{l}\text { mankarrha } \\
\text { girl }\end{array}$ & $\begin{array}{l}\text { yingki-rda } \\
\text { give-PTCPLE }\end{array}$ \\
\hline
\end{tabular}

\section{Shirkhan-nha}

\section{Shirkhan-ACC}

\section{Ngarda-nhi} then-LOC

$\begin{array}{lll}\text { nhulu } & \text { nhinha } & \text { marda } \\ \text { he-ERG } & \text { him-ACC } & \text { money }\end{array}$

3. Moosha 55

\section{yingki-rda give-PTCPLE}

yingki-rda give-PTCPLE AUX-PRES

\section{Pinarrhu Sarrawa yatha-yi "yundrru-lha ngamalka-rnda old man say-PRES you-ERG-NI have-PTCPLE}

\section{purrhi-ya nhanha-parrha." \\ AUX-IMPER her-ACC-DEF}

$\begin{array}{cllll}\text { 5. Ngarda-nhi } & \text { nhawu, } & \text { nhulu } & \text { nhanha pardaka-yi } \\ \text { then-LOC } & \text { he } & \text { he-ERG her-ACC take-PRES }\end{array}$

ngamalka-lha.

have-IMPL SS
6. Nhulu
ngara-mda
purrhi-yi
nhawh ngarla
Broken Hill
he-ERG
hear-PTCPLE AUX-PRES he
but

52 See, for example, the stories in Murray and Austin 1981, and the tale of the Afghan snake charmer in Hercus and Sutton 1986.

53 Ben told a version of this story in English to Philip Jones, noting that the Aboriginal black tracker was Mick McLean (see line 29 of the present text).

54 This is the Wangkangurru word for 'old man'. Ben uses the Diyari-Thirrari word pinarrhu later.

55 This is apparently the same Moosha described by Litchfield (1983:67) as 'a Government retainer of twenty-five years service, who had been out with several trigonometrical survey parties, and was in charge of the government camels at Farina and Marree.' There was also a Noorie Moosha who accompanied Madigan on the first crossing of the Simpson desert by white men in 1939. He is pictured in Litchfield 1983:64. 
ngama-rnda.

live-REL SS

$\begin{array}{clll}\text { 7. Nhaka-ndrru ngarda } & \text { nhawu } & \text { thurrhu } & \text { wilparra-nhi } \\ \text { there-ABL then } & \text { he } & \text { fire } & \text { vehicle-LOC }\end{array}$

$\begin{array}{lllll}\text { wirrhi-rnda } & \text { purrhi-yi } & \text { wapa-rnda } & \text { purrhi-lhali } & \text { marrhi-ya. } \\ \text { enter-PTCPLE } & \text { aux-PRES } & \text { go-PTCPLE } & \text { AUX-IMPL SS } & \text { Marre-ALL }\end{array}$

$\begin{array}{rllll}\text { 8. Wata nhawu wapa-rna purrhi-rnda } & \text { nhayi-lha } & \text { pinarrhu } \\ \text { not } & \text { he } & \text { go-PTCPLE } & \text { AUX-PTCPLE } & \text { see-IMPL SS oldman }\end{array}$

Sarrawa-nha.

Sarrawa-ACC

$\begin{array}{cllll}\begin{array}{c}\text { 9. Windrri pula } \\ \text { only }\end{array} & \begin{array}{l}\text { marnduri-ma } \\ \text { they two meet-PTCPLE }\end{array} & \begin{array}{l}\text { nhaka railway thurrhu wilparra } \\ \text { there }\end{array} & \begin{array}{l}\text { fire } \\ \text { vehicle }\end{array}\end{array}$

$\begin{array}{lll}\text { gate-anhi } & \text { mara } & \text { yingki-mali-rnda. } \\ \text { gate-LOC } & \text { hand } & \text { give-RECIP-REL SS }\end{array}$

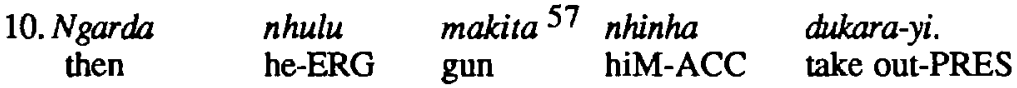

$\begin{array}{cllll}\text { 11. Maja } & \text { nhinha dandrarda } & \text { purrhi-rnda } & \text { mara warha ya kurnu } \\ \text { OK } & \text { him-ACC hit-PTCPLE } & \text { AUX-PTCPLE } & \text { hand half } & \text { and one }\end{array}$

makita thandra nhulu winma-rnda nhungkangu murnampirrha-nhi. gun fruit he-ERG insert-REL SS him LOC chest-LOC

12. Ngarda nhulu ngarangara nhinha wata thalku nandra-yi. then he-ERG heart him-ACC not straight hit-PRES

$\begin{array}{lllll}\text { 13. Nhawh } & \text { thipi-rlu } & \text { ngama-yi } & \text { ngama-rnda } & \text { purrhi-yi } 58 \\ \text { he } & \text { alive-still } & \text { sit-PRES } & \text { sit-PTCPLE } & \text { AUX-PRES }\end{array}$

14. Nhawu pinarrhu, thana-li nhinha pardakamda purrhi-yi he old man they-ERG him-ACC take-PTCPLE AUX-PRES

56 The Diyari-Thirrari term for 'train' is literally 'fire vehicle'. The word wilparra is a borrowing from English 'wheelbarrow', but it can be used to refer to any wheeled vehicle.

57 This is a loan from English 'musket'.

58 The Thirrari spoken by Ben Murray is characterised by the presence of the obligatory auxiliary verb purrhi-. Here, and at a few other places throughout the texts (for example line 15 below), Ben has first given the Diyari form of a verb and then followed it immediately by the correct Thirrari form with purrhi- . 


\section{BEN MURRAY}

pub-ya.

pub-ALL

\section{Nhaka ngarda-nhi thana-li nhinha nhayi-nhayi-pa-yi there then-LOC they-ERG him-ACC see-see-ALT-PRES}

$\begin{array}{llll}\text { nhayi-nhayi-pa-rnda } & \text { purrhi-yi } 59 & \text { kunki } & \text { wakara-rnda purrhi-rnanhi } \\ \text { see-see-ALT-PTCPLE } & \text { AUX-PRES } & \text { doctor } & \text { come-PTCPLE }\end{array}$

waya dandrarda purrhi-rnda kunki-nhi karka-rnda.

wire hit-PTCPLE AUX-REL SS dotor-LOC call-REL SS

$\begin{array}{cllll}\text { 16. Nhawh wakara-rnda } & \text { purrhi-yi } & \text { nhayi-lha } & \text { nhinha. } \\ \text { he } & \text { come-PTCPLE } & \text { AUX-PRES } & \text { see-IMPL SS him-ACC }\end{array}$

17. Maja nhawre.

OK he

$\begin{array}{lll}\text { 18. Nhingkirda } & \text { ngamalka-rnda } & \text { purrhi-ya-mayi. } \\ \text { here } & \text { keep-PTCPLE } & \text { AUX-MMPER-EMPH }\end{array}$

$\begin{array}{clll}\text { 19. Nhawn } & \text { maja } & \text { manyu-rri-lha } & \text { nganayi.' } \\ \text { he } & \text { OK } & \text { good-INCHOAT-FUT } & \text { AUX }\end{array}$

20. Nhawu ngarla nhaka-ndrnu thika-rnda purrhi-rnda.

he but there-ATL return-PTCPLE AUX-PTCPLE

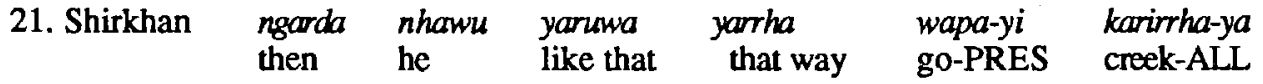

Farina-ndrnu diji durnka-nkarri wapa-mda purthi-rnda.

Farina-ablat sun rise-towards go-PTCPLE AUX-REL SS

22. Wata-lha palthu-nhi nhungkangu wardayari nhawu not-NI raad-LOC him LOC where he

Mundowdna-ya wapa-yi.

Mundowdna-ALL go-PRES

23. Windrri nhawn thalku yartha wapa-ma purrhi-rnda only he straight that way go-PTCPLE AUX-PTCPLE

\section{karirrha-nhi ngana-rnda.}

creck-LOC be-REL SS
24. Ngarda-nhi nhaka-ndrru karirrhi wirti wapa-yi yarra nhingkirda then-LOC there-ABL croek along go-PRES this way here

59 This is a further example of the correction mentioned in footnote 58 above. 


$\begin{array}{llll}\begin{array}{l}\text { Fanina-ya } \\ \text { Farina-ALL }\end{array} & \begin{array}{l}\text { thika-rnda } \\ \text { return-PTCPLE }\end{array} & \begin{array}{l}\text { purrhi-rnda. } \\ \text { AUX-REL SS }\end{array} & \\ \begin{array}{clrl}\text { 25. Nhulu } \\ \text { he-ERG }\end{array} & \begin{array}{l}\text { thidna foot puta } \\ \text { for boot }\end{array} & \begin{array}{l}\text { nhungkarni } \\ \text { his }\end{array} & \begin{array}{l}\text { dukara-yi. } \\ \text { take off-PRES }\end{array}\end{array}$

$\begin{array}{clll}\text { 26. Thidna } & \text { parlu } & \text { wopa-rnda } & \text { purrhi-yi. } \\ \text { foot } & \text { naked } & \text { go-PTCPLE } & \text { AUX-PRES }\end{array}$

$\begin{array}{llllll}\text { 27. Nhakaldrra } & \text { nhulu } & \text { thidna } & \text { puta } & \text { wirrhi-rnda } & \text { purrhi-yi } \\ \text { again } & \text { he-ERG foot } & \text { boot } & \text { put on-PTCPLE } & \text { AUX-PRES }\end{array}$

$\begin{array}{lll}\text { nhakaldra } & \text { dukara-mda } & \text { purrhi-rnda. } \\ \text { again } & \text { take off-PTCPLE } & \text { AUX-REL SS }\end{array}$

28. Yaruka ngana-rna parlka-rnda purrhi-yi.

like that be-PTCPLE go along-PTCPLE AUX-PRES

$\begin{array}{llllll}\text { 29. Ngarda-nhi } & \text { kama } & \text { nhawh } & \text { thidna wani-rna, } & \text { nhulu } \\ \text { then-LOC } & \text { man } & \text { he } & \text { foot } & \text { follow-PTCPLE he-ERG }\end{array}$

wani-yi.

Follow-PRES
30. Nhawu yulya-nhi yatha-rnda purrhi-yi "Thidna parlu nhawh he police-LOC say-PTCPLE AUX-PRES foot naked he

33. Ngathu waya dandrarda purrhi-yi yulya-nhi Farina yulya-nhi." I-ERG 'wire' hit-PTCPLE AUX-PRES police-LOC police-LOC 
BEN MURRAY

34. Nhulu nhinha wani-rnda purrhi-rnda karirrhi wirti. he-ERG him-ACC follow-PTCPLE AUX-PTCPLE creek along

35. Wata nhulu karirrhi warrara-mda purrhi-rnda. not he-ERG creek leave-PTCPLE AUX-PTCPLE

36. Nhawu wapa-rnda purrhi-yi Paradise-ya

he go-PTCPLE AUX-PTCPLE Paradise-ALL

wardayari nhawu Two Hills Dam.

where he $\begin{array}{cclll}\begin{array}{c}\text { 37. Nhaka-ndrru } \\ \text { there-ABL }\end{array} & \begin{array}{l}\text { ngarda-nhi } \\ \text { then-LOC }\end{array} & \text { nhawe } & \text { jirri-nga-yi } & \text { wirrhawarta } \\ & \text { tum off-going-PRES } & \text { Farina }\end{array}$

nhake nhawu jirri-nga-rna.

there he turn off-going-REL SS

38. Ngarda nhawu nhinha-ya karirrhi Paradise karirrhi wani-yi then he him-ACC-this creek creek follow-PRES

thidna parlu-yali.

foot naked-ERG

39. Nhakaldrra thidna puta wirrhi-rnda purrhi-yi. again foot boot put on-PTCPLE AUX-PRES

40. Nhawu wakara-yi nhaka Two Hills Dam-anhi. he come-PRES there Two Hills Dam-LOC

41. Nhulu nhakaldra thidna puta dukara-yi.

he-ERG again foot boot take off-PRES

42.Ngarda nhawu wakara-rnda purrhi-yi thidna parlu nhingkiya then he come-PTCPLE AUX-PRES foot naked here $\begin{array}{lllll}\text { karirha-nhi } & \text { wardayari } & \text { yidni } & \text { ngama-yi } & \text { karrari. } \\ \text { creek-LOC } & \text { where } & \text { you } & \text { camp-PRES } & \text { now }\end{array}$

43. Nhakaldrra nhawu thidna puta wirthi-rnda purrhi-yi. again he foot boot put on-PTCPLE AUX-PRES

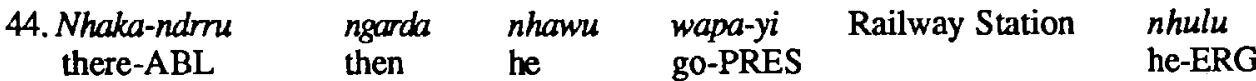

ngapa thangki fillama-tharri-rnanhi engine start'em.

water tank fill-cont-REL DS 


$\begin{array}{llll}\text { 45. Nhaka } & \text { yatha-lha } & \text { parrhayi } & \text { nhungkangu } 60 \text { 'Boss me lose'em camel, } \\ \text { there } & \text { say-FUT } & \text { AUX } & \text { him-LOC }\end{array}$

big mob of camel.'

46. Nhawe yatha-rnda purrhi-yi 'Where you lose'em?' he SAy-PTCPLE AUX-PRES

47. 'Me come long way. Marree. Frome Creek.'

48. 'I never see camel.

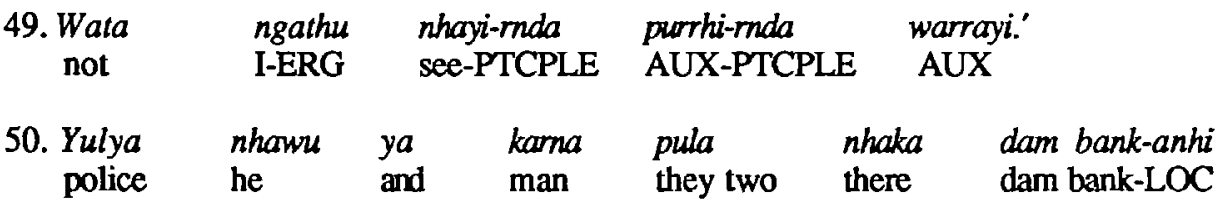
$\begin{array}{lll}\text { ngama-rnanhi } & \text { ngara-rnda } & \text { purrhi-rnda. } \\ \text { sit-REL DS } & \text { listen-PTCPLE } & \text { AUX-REL SS }\end{array}$

51.Ngarda nhawu yatha-yi 'Hey boss! Him here alright!' then he say-PRES

52.Karna nhungkangu yulya-nhi yatha-yi 'leave'em for a while.' man him LOC police-LOC say-PRES

53. Warrara-rnda purrhi-ya-mayi! leave-PTCPLE AUX-IMPER-EMPH $\begin{array}{clllll}\text { 54. Nhawu } & \text { karna } & \text { yatha-rnda } & \text { purrhi-yi } & \text { 'Nganhi } & \text { wapa-yi } \\ \text { he } & \text { man } & \text { say-PTCPLE } & \text { AUX-PRES I } & \text { go-PRES }\end{array}$

nhungkangu yatha-lha"'

him LOC talk-IMPL SS

55. 'Good day boy! Me lose'em camel.'

56. 'Oh, I see boss. I help you.

$\begin{array}{lllll}\text { 57. Ngathu } & \text { mayatha } & \text { nhayi-rnda } & \text { purrhi-yi } & \text { he didn't say yulya } \\ \text { I-ERG } & \text { boss } & \text { see-PTCPLE } & \text { AUX-PRES } & \end{array}$

60 The speech of the Afghans as characterised by Ben has many features of pidgin English, such as the use of me for first person singular subject, obligatory 'em suffix on transitive verbs, no copula (verb 'to be') and plain not for negation (see also Text I line 16. A similar characterisation is found in an example quoted by Litchfield (1983:67). Ben himself speaks standard Australian English. 


\section{BEN MURRAY}

$\begin{array}{llllll}\text { nhayi-rnda } & \text { purrhi-yi } & \text { ngathu } & \text { wanthi-pa-lha } & \text { nganayi } & \text { yingkarni. } \\ \text { see-PTCPLE } & \text { AUX-PRES } & \text { I-ERG } & \text { search-ALT-FUT } & \text { AUX } & \text { your }\end{array}$

58. Ngathu yinha maranguka-lha nganayi wanthi-rda I-ERG you-ACC help-FUT aAUX search-PTCPLE

purrhi-lha.'

AUX-IMPL SS

59. 'Alright.'

60. Yulya come then.

police

61. 'Good day boss.'

62. 'You better come up. I'll give you a drink of tea or an egg.

$\begin{array}{lllll}\text { 63. Wapa-mayi } & \text { nhayi-rnda } & \text { purrhi-lhali } & \text { kapi } & \text { kara } \\ \text { go-IMPER-EMPH } & \text { eat-PTCPLE } & \text { AUX-IMPL SS } & \text { egg } & \text { or }\end{array}$ $\begin{array}{llll}\text { thirti } & \text { kara } & \text { thapa-mda } & \text { purrhi-lhali.' } \\ \text { tea } & \text { or } & \text { drink-PTCPLE } & \text { AUX-PRES }\end{array}$

64. Ngarda-nhi pulali nhinha thika-lka-yi nhingki-nhi-ya. then-LOC they two him-ACC return-TRANS-PRES here-ALL-here

65. Nhawu kama nhungkangu yatha-rnda purrhi-yi he man him LOC say-PTCPLE AUX-PRES

Nhawu-parrha kungka-rda purrhi-yi.

he-DEF limp-PTCPLE AUX-PRES

66. Thidna dapa nhawu-parrha. foot sore he-DEF

67. Nhawu-parrha-matha! he-DEF-IDENT

68. Nhulu-matha dandranda purrhi-rnda warrayi thinka wirti.' he-ERG-IDENT hit-PTCPLE AUX-PTCPLE AUX night along

69. He asked him 'Are you hungry?

70. Minha yundru nganja-yi thayi-rnda purrhi-lha? Kapi?' what you-ERG want-PRES eat-PTCPLE AUX-IMPL SS egg

71. 'Kawu.' yes 
ABORIGINAL HISTORY 1988 12:2

72. Ngapa-nhi darha-ma wara-ma boiled egg, he wouldn't eat'em fried water-LOC boil-PTCPLE AUX-PTCPLE

'cause can't eat fat, might fry it with butter.

$\begin{array}{clll}\text { 73. Ngarda } & \text { darha-mda } & \text { purrhi-mda } & \text { thayi-rna. } \\ \text { then } & \text { boil-PTCPLE } & \text { AUX-PTCPLE } & \text { eat-REL SS }\end{array}$

74. Puka yingki-rda purrhi-rnda nhulu thayi-mda purrhi-yi. food give-PTCPLE AUX-PTCPLE he-ERG eat-PTCPLE AUX-PRES

75. Nhawu yatha-mda purrhi-yi yulya Yidni thidna dapa he say-PTCPLE AUX-PTCPLE police you foot sore

ngana-mda purrhi-yi.'

be-PTCPLE AUX-PRES

76. 'Kawn, nganhi thidna dapa.' yes I foot sore

77. Karna kurnu nhawu wakara-yi marri-ndrru. man one he come-PRES Marree-ABL $\begin{array}{lllll}\text { 78. Yaruka } & \text { nhawu } & \text { yatha-rnda } & \text { purrhi-yi } & \text { Nhawr-parrha-matha! } \\ \text { like that } & \text { he } & \text { say-PTCPLE } & \text { AUX-PRES } & \text { he-DEF-IDENT }\end{array}$

79. Nhulu-parrha-matha nhanha 62 dandra-nda purrhi-lha wirrhiyi. he-ERG-DEF-IDENT her-ACC hit-PTCPLE AUX-FUT AUX

80. Kawu. Ngathu nganja-yi nhinha thidna nhayi-rnda yes I-ERG want-PRES him-ACC foot see-PTCPLE

purrhi-lha.'

AUX-IMPL SS

$\begin{array}{llllll}\text { 81. Thidna } & \text { dapa } & \text { nhawu } & \text { kungka-rda } & \text { purrhi-mda } & \text { warrayi.' } \\ \text { foot } & \text { sore } & \text { he } & \text { limp-PTCPLE } & \text { AUX-PTCPLE } & \text { AUX }\end{array}$

82. Nhawu-parrha-matha! he-DEF-IDENT

61 The suffix -matha indicates that the speaker asserts he can identify the thing or person referred to. The closest English translation of this instance is This is him!"

62 This appears to be a mistake as the Afghan had shot Moosha, not his daughter. Probably nhinha 'him-acc' was intended. Note the use of the auxiliary verb wirrhiyi indicating action performed yesterday (see Austin 1981:90). 


\section{BEN MURRAY}

$\begin{array}{lllll}\text { 83. Nhawu thidna puta-nthu thidna parlu nhingkirda-nhi-rlu } \\ \text { he } & \text { foot } & \text { boot-PROP foot naked }\end{array}$

wapa-mida purrhi-rnda.

go-PTCPLE AUX-PTCPLE

84. Yaruka nhawu ngana-mda purrhi-rnda.

like that he be-PTCPLE AUX-PTCPLE

85. Ngathu nhinha nguyama-rnda purrhi-yi nhinha-parrha.'

I-ERG him-ACC know-PTCPLE AUX-PRES him-ACC-DEF

86. Nhawu yatha-rnda purrhi-yi kama kurnu-nhi 'Yindi he say-PTCPLE AUX-PRES man one-LOC you-ERG

pakarna nhinha-parrha nguyama-rnda purrhi-yi?"
also

87. 'Kawu. Ngathu nguyama-mda purrhi-yi.'

yes I-ERG know-PTCPLE AUX-PRES

88. Nhulu-parrha-matha nhinha pinarrhu dandrarda purrhi-lha he-ERG-DEF-IDENT him-ACC old man hit-PTCPLE aux-fut

wirrhiyi

AUX

makita-li diya-rnda purrhi-rnda."

gun-ERG shoot-PTCPLE AUX-REL SS

89. 'Alright' nhawn yatha-rnda purrhi-yi 'alright. Put me. he $\quad$ say-PTCPLE AUX-PRES

I been shoot'em. I pay 150 'e pay 200 , 'e can keep'em. You give me, I don't

know, how many year

nganhi thika-rnda purrhi-yi nhinha I return-PTCPLE AUX-PRES him-ACC

dandrourda purrhi-lha pulanha nhanha pakarna.

hit-PTCPLE AUX-IMPL SS them two-ACC her-ace also

90. Ngarda-nhi nhinha marlarle thana-li kanyangarrhi-nhi then-LOC him-ACC truly they-ERG jail-LOC

kurrha-mda purrhi-yi kilpa waldra mara parrjarna nhinha put-PTCPLE AUX-PRES cold hot hand all him-ACC

yingki-rda purrhi-rnida.

give-PTCPLE AUX-REL SS 


\begin{tabular}{|c|c|c|c|c|c|}
\hline $\begin{array}{l}\text { 91. Ngardc } \\
\text { then }\end{array}$ & & $\begin{array}{l}\text { nhawn } \\
\text { he }\end{array}$ & $\begin{array}{l}\text { durnka-rda } \\
\text { emerge-PT }\end{array}$ & PLE & $\begin{array}{l}i i-y i . \\
\text {-PRES }\end{array}$ \\
\hline $\begin{array}{l}\text { 92. Ngardc } \\
\text { then }\end{array}$ & & $\begin{array}{l}\text { thana } \\
\text { they }\end{array}$ & $\begin{array}{l}\text { yinpa-yi } \\
\text { send-PRES }\end{array}$ & $\begin{array}{l}\text { nhinha } \\
\text { him-ACC }\end{array}$ & Western Australia \\
\hline $\begin{array}{l}\text { nhaka } \\
\text { here }\end{array}$ & $\begin{array}{l}\text { nhawu } \\
\text { he }\end{array}$ & & $\begin{array}{l}\text { na-rnda } \\
\text { PTCPLE }\end{array}$ & $\begin{array}{l}\text { purrhi-rnda } \\
\text { AUX-PTC }\end{array}$ & \\
\hline
\end{tabular}
$\begin{array}{clllll}\text { 93. Ngarda } & \text { nhawu } & \text { ngana-mda purrhi-yi } & \text { kilpa waldrra mana warrha } \\ \text { then } & \text { he } & \text { be-PTCPLE AUX-PRES cold hot } & \text { hand half }\end{array}$

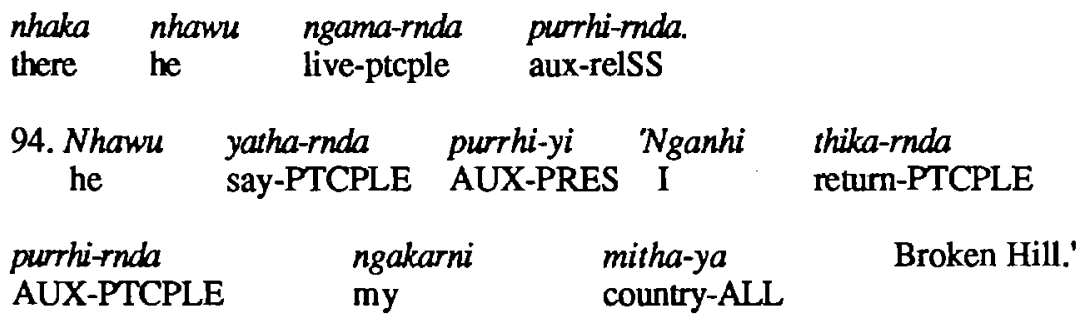

\begin{tabular}{|c|c|c|c|c|c|}
\hline $\begin{array}{l}\text { 95. Nhinha } \\
\text { him-ACC }\end{array}$ & $\begin{array}{l}\text { nhulu } \\
\text { he-ERG }\end{array}$ & $\begin{array}{l}\text { mang } \\
\text { head- }\end{array}$ & $\begin{array}{l}\text { handrra-nhi } \\
\text { OC }\end{array}$ & $\begin{array}{l}\text { kathi } \\
\text { cloth }\end{array}$ & $\begin{array}{l}\text { dukara-ma } \\
\text { take off-PTCPLE }\end{array}$ \\
\hline $\begin{array}{l}\text { witiminirri-lha } \\
\text { hat-NI }\end{array}$ & \multicolumn{2}{|c|}{$\begin{array}{l}\text { wirrhi-rnda } \\
\text { wear-PTCPLE }\end{array}$} & $\begin{array}{l}\text { purrhi-lhal } \\
\text { AUX-IMP }\end{array}$ & & \\
\hline
\end{tabular}

96. Tharla $\begin{array}{ll}\text { nhungkarni } & \text { pilki-lha } \\ \text { his } & \text { different-N }\end{array}$

dika-tharrhi-rna. name different-NI call-REFL-PTCPLE

$\begin{array}{llll}\text { 97. Yaruka } & \text { nhawu thika-rnda } & \text { purrhi-yi wata marla nhawu } \\ \text { like that he } & \text { return-PTCPLE AUX-PRES not more he }\end{array}$

$\begin{array}{llll}\text { ngundrra-rna } & \text { nhanha } & \text { wilha } \\ \text { think-PTCPLE } & \text { her-ACC } & \begin{array}{l}\text { woman } \\ \text { woma }\end{array} & \begin{array}{l}\text { padni-lha } \\ \text { no-NI }\end{array}\end{array}$

$\begin{array}{llll}\text { 98. Yaruka } & \text { nhawu } & \text { murda-rnda } & \text { purrhi-yi. } \\ \text { like that } & \text { he } & \text { finish-PTCPLE } & \text { AUX-PRES }\end{array}$

\section{Translation}

1. Old man Sarrawa he gave a girl to Shirkhan.

2. Then he gave him money $£ 150$.

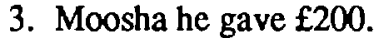

4. Old man Sarrawa said 'you have her now.'

5. Then he took her to have her.

6. He [Shirkhan] heard about it but he was living in Broken Hill.

7. He caught a train from there and went to Marree.

8. He didn't go to see old man Sarrawa.

9. Only the two of them met there at the railway gate and shook hands.

10. Then he [Shirkhan] pulled out his gun. 
11. He shot him, putting six bullets into his chest.

12. But he didn't hit him straight in the heart.

13. He was still alive.

14. The old man, they carried him to the pub.

15. Then they looked after him there while the doctor came, sending a wire (telegram) calling the doctor.

16. He came to look at him.

17. 'He's alright.

18. Keep him here.

19. He'll get better.'

20. But he [Shirkhan] went back from there.

21. Shirkhan then went that way to the creek from Farina, going towards the west.

22. He didn't go on the road that goes to Mundowdna.

23 . He only went straight that way to the creek.

24. Then from there he went along the creek this way here coming back to Farina.

25. He took off his boots.

26. He went without any boots on.

27. He put his boots on again and took them off again.

28. That's how he went along.

29. Then an Aborigine [black tracker], he followed the tracks.

30. He said to the policeman 'He went along barefoot.'

31. Then the two of them followed him like that, (sometimes) barefoot, (sometimes) with shoes on, along the creek.

32. Then that way in the creek from Mundowdna siding the policeman said to him 'You follow him to Farina while I go back.

33. I'll send a wire to the Farina police.'

34. He [the tracker] followed him along the creek.

35. He didn't leave the creek.

36. He went to the Paradise (Creek) where the Two Hills Dam is.

37. From there then he turned off, turning off there at Farina.

38. Then he followed the Paradise Creek in bare feet.

39. He put his boots on again.

40. He came there to Two Hills Dam.

41. He took his boots off again.

42. Then he came barefoot here to the creek where you are camped now.

43. Again he put his boots on.

44. From there he went to the Railway Station where he [an engineer] was filling a water tank to start the engine.

45. There he said to him 'Boss me lose'em camel, big mob of camel.'

46. He said 'where you lose'em?'

47. 'Me come long way. Marree. Frome Creek.'

48. 'I never see camel.

49. I didn't see them.'

50. The policeman and Aborigine [tracker] were sitting there on the dam bank listening.

51. Then he [the tracker] said 'Hey boss! Him here alright!'

52. The Aborigine said to the policeman 'Leave'em for a while.

53. Leave him!'

54. The Aborigine said 'I'll go to talk to him.'

55.'Good day boy! Me lose'em camel.'

56. 'Oh, I see boss. I help you. 
57. I'll see the boss, he didn't say policeman, I'll see him and I'll search for you.

58. I'll help you to search.'

59. Policeman corne then.

61. 'Good-day boss.' [said the Afghan]

62. 'You better come up. I'll give you a drink of tea or an egg.

63. Come to eat an egg or drink a cup of tea.'

64. Then the two of them brought him back here.

65. The Aborigine said to him [the policeman] 'He's limping.'

66. His feet are sore.

67. This must be him!

68. He must have shot him during the night.'

69. He [the policeman] asked him [Shirkhan] 'Are you hungry?

70. What do you want to eat? An egg?'

71. 'Yes'

72. He boiled it in some water, boiled egg 'cause he wouldn't eat'ern fried, 'cause can't eat fat, might fry it with butter.

73. Then he boiled it and ate it.

74. They gave him food and he ate it.

75. The policeman said 'Your feet are sore.'

76. 'Yes, my feet are sore.'

77. One Aborigine came down from Marree.

78. He said like this: 'That's him!

79. He's the one who shot him yesterday.'

80. 'Yes. I want to see his feet.'

81. 'He limped along with sore feet.'

82. "That's him!

83. He walked along with his boots on and in bare feet right to here.

84. That's how he was.

85. I know him, that one.'

86. He said to another Aborigine 'Do you know him too?'

87. 'Yes. I know.

88. He's the one who shot the old man with a gun yesterday.'

89. 'Alright' he said 'alright. Put me. I been shoot'em. I pay 150 'e pay 200 , 'e can keep'em. You give me, I don't know, how many year I will come back to kill him, them two, her also.'

90. Then they really put him in jail, giving him ten years.

91. Then he came out [of jail].

92. Then they sent him to Western Australia and he lived there.

93. He lived there for five years.

94. He said 'I'm going to go back to my own country Broken Hill.'

95. He took off his head cloth (turban).

96. He called himself by a different name.

97. That's how he went back, not thinking about the Moosha woman, thinking about nothing now.

98. That's how he finished.

Text I 'Black Bastards'

Recorded by Peter Austin at Farina 27th November 1975 (fieldtape D34b, transcription Book III pp131-2) 


\section{BEN MURRAY}

The Afghans came in for a share of the racism often directed towards Aborigines, especially by Queensland drovers travelling the Birdsville Track stock route. One drover got a shock when he insulted Akbar Khan, an Afghan camel driver with whom Ben was working. $\begin{array}{rlll}\text { 1. Ngarda-nhi } & \text { ngayani } & \text { ngana-rnda } & \text { purrhi-yi } \\ \text { then-LOC } & \text { we PL EXCL } & \text { be-PTCPLE } & \text { AUX-PRES }\end{array} \quad \begin{aligned} & \text { karirrha-nhi. } \\ & \text { creek-LOC }\end{aligned}$

2. Drover come along wakara-mda purrhi-yi.

come-PTCPLE AUX-PRES

3. Nhawu yatha-rnda purrhi-yi.

he say-PTCPLE AUX-PRES

4. 'You black bastards. What are you doing on my road? You clear the bloody road!'

5. No, no, no. This is a public road, we gotta be here.

6. Ngayana palthu ngayanirni ngana-yi. we PL INCL road our PL INCL be-PRES

7. Yingkarni pudluka wata nhingkirda wapa-rnda purrhi-yi.' your cattle not here go-PTCPLE AUX-PRES

8. 'Yurra ngakarni nhantu yapa yingki-rda purrhi-yi.'63 you PL my horse fear give-PTCPLE AUX-PRES

9. 'Padni. Ngapu-rri-rnda no quiet-INCHOAT-PTCPLE AUX-IMPER-EMPH

10. Ngathu yinha dantorarda purrhi-yathi' told Akbar. I-ERG you-ACC hit-PTCPLE AUX-PTCPLE

11. 'Alright, you try!

12. Nganha dandrra-rda purrhi-ya-mayi!" me-ACC hit-PTCPLE AUX-IMPER-EMPH

13. Akbar off into it, too tough for him.

$\begin{array}{cllll}\text { 14. } \begin{array}{ll}\text { Mayi, } \\ \text { well }\end{array} & \text { hhulu } & \text { nhinha } & \text { dandrrarda } & \text { purrhi-mda. } \\ & \text { he-ERG } & \text { him-ACC } & \text { hit-PTCPLE } & \text { AUX-PTCPLE }\end{array}$

15. 'I'll meet you again next time.'

63 The smell of camels is particularly upsetting to horses. If a camel team and a mob of cattle were camped at the same place overnight, the camels had to be hobbled downwind of the cattle and horses. 


\section{ABORIGINAL HISTORY 1988 12:2}

16. 'Alright. You meet me any time you like. If you come my camp. Me camp Well Creek tonight. Me and Benny camp Well Creek. Me turn'em camel that way, 'e turn'em this way. Alright you come there.'

$\begin{array}{clll}\begin{array}{c}\text { 17. Nhawh } \\ \text { he }\end{array} & \text { wata } & \text { wakara-rnda } & \text { purrhi-yi. } \\ & \text { come-PTCPLE } & \text { AUX-PTCPLE }\end{array}$

\section{Nhulu dandra-rda purrhi-lha nganayi thana-nha. he-ERG hit-PTCPLE AUX-FUT AUX them-ACC}

$\begin{array}{cllll}\text { 19. Waranha } & \text { nhungkangu } & \text { thirrhi } & \text { ngana-rnda } & \text { purrhi-rnda nhulu } \\ \text { who } & \text { him LOC } & \text { angry } & \text { be-PTCPLE } & \text { AUX-PTCPLE he-ERG }\end{array}$

\section{dandrra-rda.}

hit-PTCPLE

\section{Translation}

1. Then we were in the Frome Creek.

2. A drover came along.

3. He said.

4. 'You black bastards. What are you doing on my raad? You clear the bloody road!'

5. No, no, no. This is a public road, we gotta be here.

6. This is our road.

7. Your cattle shouldn't go here.'

8. 'You are frightening my horses.'

9. 'No. Shut up!'

10. '(Look out) or else I'll hit you' (he) told Akbar.

11. 'Alright, you try!

12. Hit me!'

13. Akbar off into it, too tough for him.

14. Well, he hit him.

15. 'I'll meet you again next time' [said the drover]

16. 'Alright. You meet me any time you like. If you come my camp. Me camp Well Creek tonight. Me and Benny camp Well Creek. Me turn'em camel that way, 'e turn'em this way. Alright, you come there.'

17. He didn't come.

18. He would have hit them all.

19. Whoever was angry with him, he hit them.

On the mission, Ben lived in single-men's quarters - a single roomed mud-brick house near the church. He shared this accommodation with other stockmen when they came in from their work on the outlying run. Despite his position of responsibility at the mission, Ben was not entirely aligned with the missionaries. He had his own view of their morality and behaviour and while he did not participate in ceremonial activity himself, he believed in the right of Aboriginal people at the mission to maintain their traditional practices and beliefs. Although he attended church services and sang hymns with the other mission Christians in Diyari and listened to Riedel's Diyari sermons, Ben joined in defying Riedel's ban on Sabbath activity and games, by slipping off to the sandhills, a mile or so away from the mission, to play games with boomerangs (for example kunduwarra, a game played 


\section{BEN MURRAY}

by throwing a boomerang end over end) or kukuru (played with a ricocheting wooden missile on claypans or along cleared 'alleys' in the bush) with other boys and men:

We used to get out there on the sandhill you know, and play game, made out of a long stick...throw it onto the grass and it run along. We used to play game and we thought that was alright, no harm in doing it. If they found out they'd soon cut it out. 64

Women played games with emu-feather balls or balls made from sewn rags or socks: they play with that...pass it to one another, another girl, they might try to jump in and take it away, grab it. ${ }^{65}$

Fishing was another activity which Ben enjoyed in his rare moments of leisure at Killalpaninna. He watched the older people make vegetable fibre nets, up to sixty metres long, which they would set on posts in the lake or the Killalpaninna channel, or smaller nets with 'wings' which the fisherman would enclose around a school of fish.

By 1913 Killalpaninna mission was in deep financial trouble. No useful rain had fallen for several years and the Cooper's last flood had been in August 1906. In April 1913 the Mission Committee purchased the de Pierres' adjoining run of 119 square miles in an effort to boost their income. The drought continued however and it became clear that the Lutheran Synod could not support both Hermannsburg and Killalpaninna missions. This was despite various attempts to economise, including major re-locations of stock between Hermannsburg and Killalpaninna. Ben participated in the last of these in 1913. With ten or so other Aborginal stockmen he rode to Warrina, south of Oodnadatta, to take charge of a mob of 1000 cattle brought there by Hermannsburg stockmen. The trip took Ben and the others about three weeks.

By the outbreak of World War I in August 1914, Killalpaninna's debt exceeded 5000 pounds and showed no sign of diminishing. Barely 100 Aboriginal people were living on the mission and it became clear that the enterprise could not continue. A complete disintegration of the community was averted by the Synod's agreement with Pastors Bogner and Jaensch to purchase Killalpaninna for 5000 pounds. They undertook to continue mission work and the Synod provided a school-teacher in return. Despite the new arrangement, for Ben, and for many other Aboriginal people the mission had 'broken up' with the departure of Pastor Riedel for the south at the end of 1914 and the outbreak of World War One. Ben's mother died at this time too, and Ben saw no alternative but to go south as well, leaving his camel business to his brother Em:

When Pastor Riedel left, I left too...I lost everything. My brother [Em], youngest brother, took it over, and another boy. They worked the camels and mission blokes went away, parson went away, all broke up. 66

\section{Gallipoli}

Ben has firm opinions on the economic management of Killalpaninna during its final years, sharing Pastor Riedel's view that the roles of station manager and missionary should have been separated. Another reason was also apparent for the rapid decline of the mission after 1910. For Ben the connection between the outbreak of the war, local ill-feeling against the Germans, and the decision to sell Killalpaninna to private owners was obvious. As he expressed it, people in the north had a 'set on the Germans' and during his trips to Marree Ben found that he was increasingly criticised for associating with them. While there 
is no evidence that popular feeling against the Germans precipitated the Synod's sale of Killalpaninna, Ben nevertheless felt the strength of this opinion, a factor which must have influenced his decision to enlist as a private in the Light Horse.

While still at Killalpaninna during the first half of 1915, Ben received letters (like other young Australian men at the time) sent anonymously by girls and women inspired by patriotism. These letters exhorted him to volunteer for the army and 'to fight for King and country'. Ben was bewildered and quite upset by this pressure and maintains that when he did join the army it was for his own reasons:

them girls...they was cheeky...not only me, some other blokes too...letter from everywhere...I never answered them. No good - try to force you to fight! Fight for King and country! I did go, I went to Gallipoli...just wanted to have a look at countries then, different countries. ${ }^{67}$

The details of Ben's enlistment are unclear; his personal papers, uniform and medals were destroyed by fire in $1979 .^{68}$ Ben recalls that he travelled south by train from Marree, first to Quorn and then to Port Augusta. Here he 'got in touch with the military', together with two German boys (probably related to Helen Jericho, one of the Vogelsang children) in mid-1915. After a brief period of training (probably at the Mitcham camp in Adelaide), when he was taught to shoot 'just roughly', Ben set off to Gallipoli with a Light Horse Regiment later in the year.

By the time of their arrival, the Australian assault on Gallipoli had only a few weeks to run ('We got there too late'). This fact, the long sea voyage there and back, the ferocity of the battle itself, and Ben's capture by the Turks, must have given the whole experience an air of unreality for Ben. Despite this, his recollections of his time at Gallipoli are graphic.

Turkish snipers swept the landing craft with fire ('bullet flying everywhere') as the men entered them for the landing. At least two men in Ben's boat were killed as they neared the shore. Ben and other men detected the Turkish snipers standing on the cliffs, camouflaged with bushes, and they pleaded with their sergeant major to shoot back at them. According to Ben this man, named Wyatt, was a rigid disciplinarian who had already alienated himself from the men. Like other officers, he carried a baton and did not hesitate to use it to enforce discipline ('treat[ed] you like a dog). He did not allow the men to shoot back at the snipers, refusing to admit that the bullets came from the bushes on the cliffs. Ben tells the story:

When we got there, just like a tree standing, all along on the bank [cliffs]. I see one dropping down...'Hello! Oh!', I sing out to the others: 'Shoot the trees, that's where the bullet come from'. We told the sergeant major, 'Shoot at them trees!'. No, no, that way the bullet come from' [he said]...He didn't even take notice. He got shot anyway, he was too smart. 'You'll get hit directly' [Ben said]...and he did...'Yeah, I bet your time will come'. His time didn't waste time! His time come alright, drop him dead too, right on the bank! We start shooting at the trees then. You see the people dropping,

67 M-J, 2.2.88.

68 A Benjamin Murray enlisted as Private No. 3085 on 27th June 1914 and was discharged from the 53rd Battalion on 17th March 1919. If this was Ben Murray (currently subject to confirmation), it suggests that he went on to fight in Palestine following the Australian evacuation from Gallipoli in December 1915, and did not return to Australia until the war was over. 


\section{BEN MURRAY}

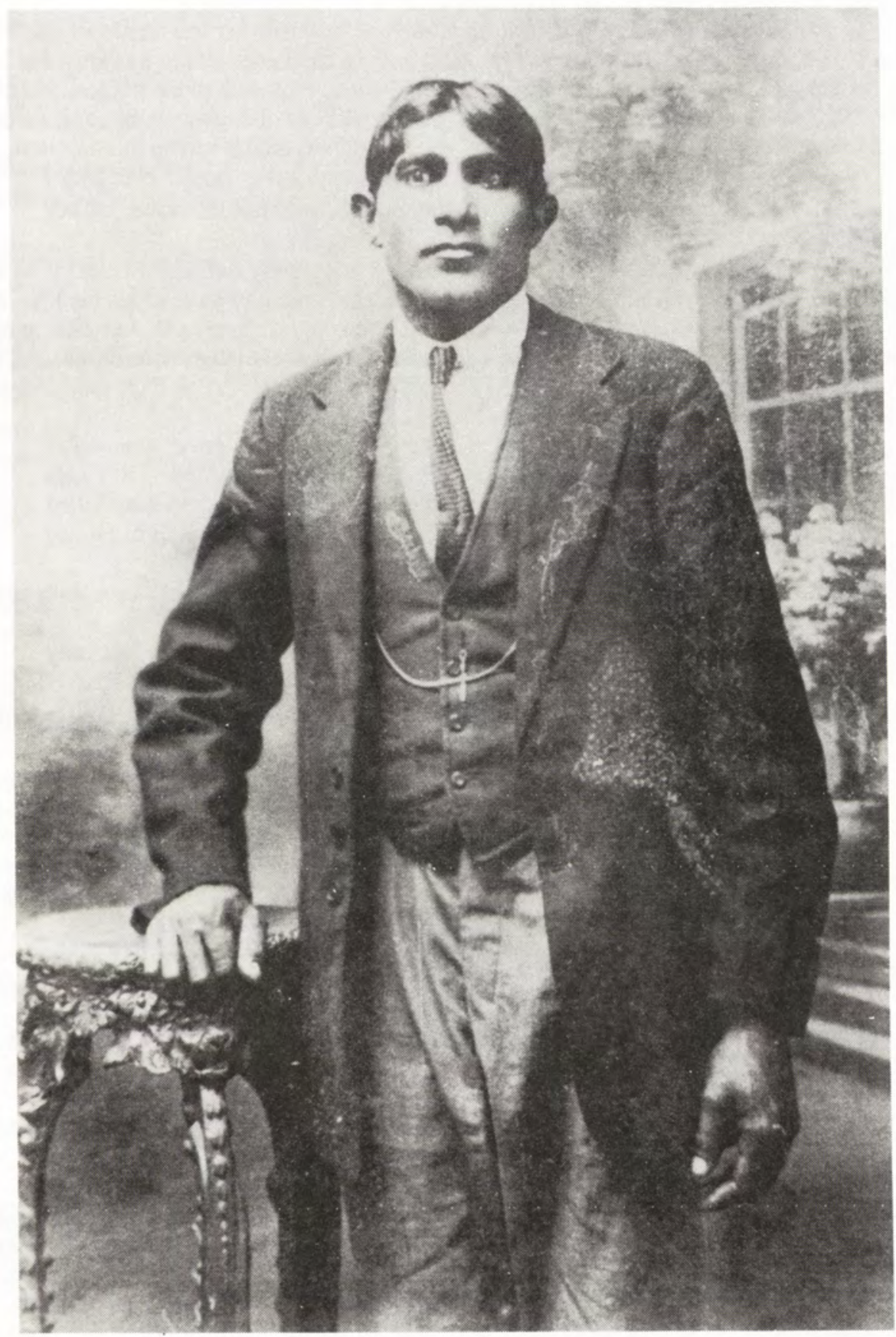

Studio portrait of Ben Murray, possibly taken just before enlistment for First World War. Photo: Hermann Vogelsang, Lutheran Archives collection. 


\section{ABORIGINAL HISTORY 1988 12:2}

'trees' falling over. Blokes running away, Turks, Turks running away. We got into them properly then. 69

With the passing of the years Ben has apparently telescoped his memories of the First World War and it is difficult to reconstruct the sequence of events. It seems likely that Ben went on after Gallipoli to fight in Palestine, and that in one of those battles, possibly during 1916, he was captured by the Turks. Ben recalls his unit making an advance on a town and that the Turks counter-attacked, killing Australians and narrowly missing Ben.

I got a bullet too, the coat here - just missed my guts. And I dropped, I dropped and I lay there then, with the other dead boys. Mates of mine ${ }^{70}$..They never missed them. 71

The Turkish soldiers were close by now, near enough apparently to finish Ben off if he had made the wrong move. His response was quick, unusual and may have saved his life. For Ben there was little to separate Turks from the Afghans he had known in Australia and so he called out the few words he had learnt from his Afghan cameleer acquaintances - the Muslim prayer uttered by them before they slaughtered a beast - as well as some Afghan names:

I sang out: 'Moosha malad! Akbar! Dadleh! Bejah! [Ben's father's name]'. I said: 'Bejah! Dadleh!' That's what I said. And they take me then. They kept me. Better than getting a bullet! If I didn't sing out...they would have killed me alright! They put a bullet through me - just missed coat [i.e. passed through coat]. But the second bullet didn't come, never come. ${ }^{72}$

And so Ben became a prisoner of the Turks, if only briefly. He was kept with other Australian prisoners in an open compound for at least a fortnight:

I couldn't get away, 'cause they were watching you, all the time. Not only me, lot more, Australians...we waited. ${ }^{73}$

He apparently got on well with his captors and must have intrigued them, both with his appearance and his understanding of Islamic customs:

Oh yes, they'd speak to you...speak about the war. They'd say it's no good, all the fighting. Oh yes, they was very friendly, them Turks. ${ }^{74}$

They talked about Australia too - in fact two of Ben's Turkish captors later made their way to Darwin. He met them by chance during his visit there in about 1942.

Ben's capture must have occurred in the final weeks of the war. That is how he remembers it. His freedom came with the armistice on 11th November 1918:

I been with the Turks...about two weeks...till they say, well, 'Finish now, war's over'. I thank them and they thank me, very good. ${ }^{75}$

69 M-J, 3.11.83; 31.7.87.

70 M-J, 9.1.88.

71 M-J, 9.1.88. It is unclear from Ben's account whether he was actually wounded in this exchange. If so, it may account for his quick retum to Australia and subsequent release from the army.

72 These men were Jack Davis, from New South Wales, and 'Jimmy' Jean, a Queenslanier.

73 M-J. 9.1.88.

74 M-J, 9.1.88.

75 M-J, 9.1.88. 


\section{BEN MURRAY}

TEXT J 'In the South'

Recorded by Peter Austin at Farina 21st November 1975 (fieldtape D31a, transcription Book III pp 99-100) Ben gives a brief résumé in Diyari of his experiences after the War.

\section{Robertstown-andrru nganhi wapa-mda purrhi-yi Waikerie Robertstown-ABL I go-PTCPLE AUX-PRES}

mitha-ya.

country-ALL

2. Nhaka ngathu nganka-rda purrhi-yi..

there I-ERG work-PTCPLE AUX-PRES

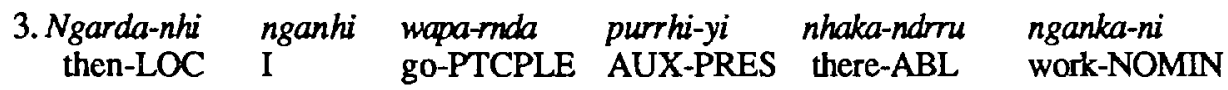

warrara-rnda purrhi-rnda.

leave-PTCPLE AUX-REL SS

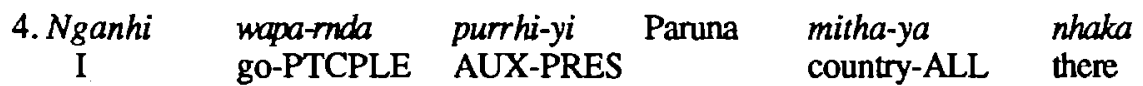

nganka-rda purrhi-lhali palthu-nhi nganka-rda purrhi-rnda.

work-PTCPLE AUX-IMPL SS road-LOC work-PTCPLE AUX-REL SS

$\begin{array}{cllll}\begin{array}{c}\text { 5. Nhungkangu-ka } \\ \text { that LOC-SPEC }\end{array} & \begin{array}{l}\text { kilpa waldrra-nhi76 } \\ \text { cold hot-LOC }\end{array} & 1927 & \begin{array}{l}\text { ngathu } \\ \text { I-ERG }\end{array} & \begin{array}{l}\text { nganka-rda } \\ \text { work-PTCPLE }\end{array}\end{array}$

purrhi-ya.

AUX-PAST

$\begin{array}{llllll}\text { 6. Ngarda-nhi } & \text { nganhi } & \text { nhungkangu-ka } & \text { diji-nhi } & \text { nganhi } & \text { wapa-rnda } \\ \text { then-LOC } & \text { I } & \text { that LOC-SPEC } & \text { day-LOC } & \text { I } & \text { go-PTCPLE }\end{array}$

purrhi-yi Pinaroo mitha-ya nhayi-rnda purrhi-lhali..

AUX-PRES country-ALL look-PTCPLE AUX-IMPL SS

7. Thika-rnda purrhi-yi ya nganka-rda purrhi-lhali.. return-PTCPLE AUX-PRES and work-PTCPLE AUX-IMPL SS

8. 1929 nganhi wapa-rnda purrhi-yi Murrayville mitha-ya I go-PTCPLE AUX-PRES country-ALL

next through the border from Pinaroo.

9. Nhawu panturra-nhi wirhi-nga-rna yarrha nhaka nhawu he boundary-LOC enter-going-PTCPLE that way there he

76 The Diyari and Thirrari term for 'year' is kilpa waldrra, literally 'cold (and) hot'. 


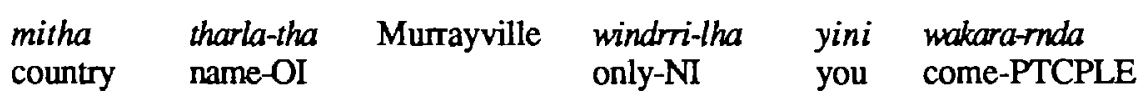

purrhi-lhali

AUX-IMPL SS

10. Ngarda-nhi then-LOC

Ouyen.

11. Yaruka nganhi wapa-mda purrhi-mda wanthiyi like that I go-PTCPLE AUX-PRES AUX

wirari-rnda-yina

$$
\text { wakara-mda }
$$

purrhi-yi Mildura

come-PTCPLE

AUX-PRES

nhayi-mda

purrhi-lhali

mitha.

go about-PTCPLE-TAG look-PTCPLE AUX-IMPL SS country

$\begin{array}{lllll}\begin{array}{l}\text { 12. Ngarda-nhi } \\ \text { then-LOC }\end{array} & \begin{array}{l}\text { thika-rnda } \\ \text { return-PTCPLE }\end{array} & \begin{array}{l}\text { purrhi-yi } \\ \text { AUX-PRES }\end{array} & \begin{array}{l}\text { ngapa-nhi } \\ \text { water-LOC }\end{array} & \begin{array}{l}\text { boat-nhi } \\ \text { boat-LOC }\end{array} \\ \text { wirrhi-rnda } & \text { purrhi-rnda. } & & \\ \text { enter-PTCPLE } & \text { AUX-REL SS }\end{array}$

$\begin{array}{lllll}\text { 13. Boat tharla nhungkarni } & \text { ngana-rnda purrhi-yi } & \text { Jimmy-nha. } \\ \text { name his } & \text { be-PTCPLE } & \text { AUX-PRES Jimmy-MASC PN }\end{array}$

14. Thika-rnda purrhi-yi Waikerie mitha-ya. return-PTCPLE AUX-PRES country-ALL

$\begin{array}{cllll}\text { 15. Nhaka-ndrru } & \text { nganhi } & \text { nhakaldrra } & \text { thika-rnda } & \text { purrhi-yi } \\ \text { there-ABL } & \text { I } & \text { again } & \text { return-PTCPLE } & \text { AUX-PRES }\end{array}$

Loxton mitha-ya Loxton, Paruna, Alawoona. country-ALL

$\begin{array}{lllll}\text { 16. Nhaka-ndrru } & \text { ngathu } & \text { palthu-nhi } & \text { nganka-rda } & \text { purrhi-ya } \\ \text { there-ABL } & \text { I-ERG } & \text { road-LOC } & \text { work-PTCPLE } & \text { AUX-PAST }\end{array}$

$\begin{array}{lllll}\text { palthu-nhi } & \text { nganka-rda } & \text { purrhi-rnda } & \text { windrri } & \text { nhantu-yali } \\ \text { road-LOC } & \text { work-PTCPLE } & \text { AUX-REL SS } & \text { only } & \text { horse-ERG }\end{array}$

marda waltha-rnda purrhi-rnda.

stone carry-PTCPLE AUX-REL SS
17. Ngarda-nhi nhaka-ndrre nganhi wxpa-mda purrhi-yi wopa-mda then-LOC there-ABL I go-PTCPLE AUX-PRES go-PTCPLE
purrhi-rnda
1932.




\section{BEN MURRAY}

$\begin{array}{cllll}\text { 18. Nganhi } & \text { wapa-mda } \\ \text { I } & \text { go-PTCPLE } & \text { purrhi-yi } & \text { AUX-PRES }\end{array}$ Kadina $\begin{aligned} & \text { mitha-nhi Wallaroo, Moonta } \\ & \text { country-LOC }\end{aligned}$

thanangu-ka mitha-nhi.

they LOC-SPEC country-LOC

$\begin{array}{llllll}\text { 19. Nhaka } & \text { ngathu } & \text { nganka-rda purrhi-yi farm-anhi windrri nhaws } \\ \text { there } & \text { I-ERG } & \text { work-PTCPLE AUX-PRES farm-LOC } & \text { only he }\end{array}$

$\begin{array}{lllll}\text { kilpa } & \text { waldrra } & \text { murda-rnanthu } 77 & \text { merda-mda } & \text { purrhi-yani } \\ \text { cold } & \text { hot } & \text { end-IMPL DS } & \text { end-PTCPLE } & \text { AUX-IML DS }\end{array}$

\begin{tabular}{|c|c|c|c|}
\hline $\begin{array}{l}\text { Nganhi } \\
\text { I }\end{array}$ & $\begin{array}{l}\text { thika-rnda } \\
\text { return-PTCPLE }\end{array}$ & $\begin{array}{l}\text { purrhi-yi } \\
\text { AUX-PRES }\end{array}$ & Adelaide \\
\hline
\end{tabular}

$\begin{array}{cllll}\text { 21. Nhaka-ndrru } & \text { nganhi } & \text { wapa-mda } & \text { purrhi-yi } & \text { thika-rnda } \\ \text { there-ABL } & \text { I } & \text { go-PTCPLE } & \text { AUX-PRES } & \text { return-ptcple }\end{array}$

purrhi-rnda Murnpeowie mitha-ya 1934.

AUX-REL SS country-ALL

$\begin{array}{lllll}\begin{array}{l}\text { 22. Nhaka ngathu } \\ \text { there I-ERG }\end{array} & \begin{array}{l}\text { nganka-rda } \\ \text { work-PTCPLE }\end{array} & \begin{array}{l}\text { purrhi-yi } \\ \text { AUX-PRES }\end{array} & \begin{array}{l}\text { nhungkangu } \\ \text { he LOC }\end{array} & \begin{array}{l}\text { panturra-nhi } \\ \text { boundary-LOC }\end{array} \\ \begin{array}{llllll}\text { minha-nhi-ya } & \text { wardayarri } & \text { nhawh kinthala kinthala } & \text { warara-ni } \\ \text { what-LOC-EMPH } & \text { where } & \text { he } & \operatorname{dog} & \operatorname{dog} & \text { leave-NOMIN }\end{array}\end{array}$

patika ngana-yi.

paddock be-PRES

\begin{tabular}{|c|c|c|c|}
\hline $\begin{array}{l}\text { 23. Nhaka } \\
\text { there }\end{array}$ & nganhi & $\begin{array}{l}\text { ngana-rnda } \\
\text { be-PTCPLE }\end{array}$ & $\begin{array}{l}\text { Durrhi-ya. } \\
\text { AUX-PAST }\end{array}$ \\
\hline $\begin{array}{l}\text { 24. Ngarda } \\
\text { then }\end{array}$ & $\begin{array}{l}\text { nganhi } \\
\text { I }\end{array}$ & $\begin{array}{l}\text { wakara-rnda } \\
\text { come-PTCPLE }\end{array}$ & $\begin{array}{l}\text { purrhi-yi Witchelina } \\
\text { AUX-PRES }\end{array}$ \\
\hline $\begin{array}{l}\text { 25. Ngarda } \\
\text { then }\end{array}$ & $\begin{array}{l}\text { nhaka-nhi } \\
\text { there-LOC }\end{array}$ & $\begin{array}{l}\text { ngathu } \\
\text { I-ERG }\end{array}$ & $\begin{array}{ll}\text { nganka-rda purrhi-yi ngurha-rlu } \\
\text { work-PTCPLE }\end{array}$ \\
\hline $\begin{array}{l}\text { ganke } \\
\text { vork- }\end{array}$ & $\begin{array}{l}\text { purrh } \\
\text { AUX }\end{array}$ & $\begin{array}{l}\text { hi-rnda } \\
\text { X-REL SS }\end{array}$ & $\begin{array}{ll}\text { jipijipi } & \text { nhayi-nhayi-pa-rna } \\
\text { sheep } & \text { look-look-ALT-REL SS }\end{array}$ \\
\hline
\end{tabular}

77 As noted above, the Thirrari spoken by Ben Murray is characterised by the presence of the obligatory auxiliary verb purrhi-. Here, and in line 25 below, Ben has first given the Diyari form of a verb and then followed it immediately by the correct Thirrari form with purrhi-. Notice that the verb inflections for implicated clause same-subject in the two languages are different (-rnanthu in Diyari, and -yani in Thirrari). 
nhayi-nhayi-pa-rnda

look-look-ALT-PTCPLE

26. Nhaka-ndrru nganhi there-ABL purrhi-rnda.

AUX-REL SS

$\begin{array}{lllll}\text { ngana-mda } & \text { purrhi-lhali Farina } & \text { mitha-nhi } & \text { ya } & \text { putha parlpa } \\ \text { live-PTCPLE } & \text { AUX-REL SS } & & \text { country-loc } & \text { and }\end{array}$

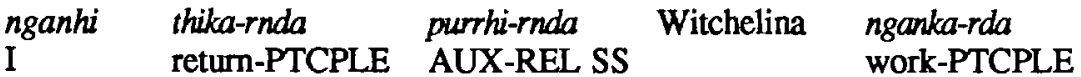

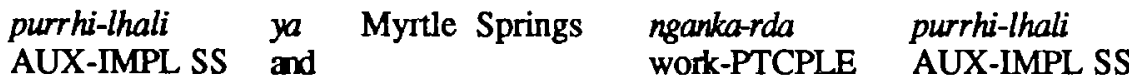

27. Kilpa waldrra-nhi yaruka nganarnda purrhi-rnda nganka-rda cold hot-LOC like that be-PTCPLE AUX-REL SS work-PTCPLE

purrhi-lhali

AUX-IMPL SS

wapa-rnda purrhi-rnda.

go-PTCPLE AUX-REL SS

28. Thana-li nganha yakalka-rnda purrhi-ya.

they-ERG me-ACC ask-PTCPLE AUX-PAST

$\begin{array}{ccccc}\text { 29. Wata } & \text { marla } & \text { nganja-yi } & \text { wapa-rnda } & \text { purrhi-lhali. } \\ \text { not } & \text { more } & \text { want-PRES } & \text { go-PTCPLE } & \text { AUX-IMPL SS }\end{array}$

\section{Translation}

1. From Robertstown I went to Waikerie.

2. I worked there.

3. Then I went from there leaving work.

4. I went to Paruna and worked there, working on the road.

5. That was the year 1927 when I worked there.

6. Then on that day I went to Pinnaroo to have a look.

7. I came back and worked.

8. In 1929 I went to Murrayville, next through the border from Pinnaroo.

9. It is through the boundary that way, the country is called Murrayville, just before you come to Ouyen.

10. Then I came to Mildura.

11. That's how I went, going about to look at the country.

12. Then I came back on the water, getting on a boat.

13. The boat's name was Jimmy.

14. I went back to Waikerie.

15. From there I went back again to Loxton, Loxton, Paruna, Alawoona.

16. From there I worked on the roads, just carrying the rocks with horses.

17. Then I went from there in 1932.

18. I went to Kadina, Wallaroo, Moonta, to those places.

19. There I worked on a farm, only to the end of the year 1932.

20. I came back to Adelaide.

21. From there I came back to Murnpeowie in 1934. 


\section{BEN MURRAY}

22. There I worked on the boundary, what's-it, where the paddock is for leaving the dogs [the dingo fence].

23. That's where I was.

24. Then I came to Witchelina in 1950.

25. Then I worked there, always working looking after sheep.

26. From there I came back in 1959 to live here in Farina and sometimes I went back to Witchelina to work, and to Myrtle Springs to work.

27. For years that's how it was, going and working.

28. They asked me.

29. I don't want to go any more.

\section{The 1920s: Down South}

It is unclear under which conditions Ben was discharged from the army upon returning to Australia. He may have been wounded at Gallipoli, as his account suggests, and this would account for an early discharge. He remembers asking to go, and being allowed: 'I went away, I told them that I wanted to go..."Oh, alright".'

With the closure of Killalpannina mission, the German community there had fractured, moving south to join relatives in forming communities in the mid-North, the Barossa valley, and near the Murray River. In retaining his connections with the Killalpaninna Germans, Ben's fortunes became linked with the most cohesive of these communities, in the small town of Lowbank, near Waikerie on the Murray River. Ben's cousins Walter and Selma Merrick lived there with their family, together with Ben's friend Wilhelm Riedel (the Killalpaninna missionary), the Vogelsangs, Paschkes and Rohrlachs. After living through droughts and sandstorms on the shores of the empty lake at Killalpaninna, it is not surprising that this small community had re-established itself so close to Australia's greatest river.

Ben went first to Robertstown though, west of the River, where he worked for a farmer named Heinrich. This man was a relative of one of the schoolteachers at the Hermannsburg Lutheran mission near Alice Springs and Pastor Riedel had probably arranged this job for Ben. Here Ben's skills as a stockman were of little help; he had to leam the business of wheat-farming, from harvesting grain to sewing wheat bags. After a year or so he moved to Robertstown itself and found work lumping wheat for a buyer - 'heavy work!'. This job was followed by more farm work west of the town, for a man named Killo at 'Brady Creek'.

By now it was probably about 1924 or 1925 . At this time Ben received a letter from one of his old Killalpaninna friends, Jack Rohrlach, asking him to help him build a new house at Lowbank. Rohrlach had married one of the Vogelsang daughters and had moved there soon after the missions closed. Ben was more than happy to rejoin his friends and relatives at Lowbank. He mixed mortar and helped with the Rohrbach house before taking up another farm labouring job, initially for the Paschke brothers, who had property nearby and then in the dry mallee country near Karoonda, for a farmer called English.

Despite the drought years of the 1920s, this period saw much of South Australia's marginal farming land cleared for crops and as settlement proceeded, so did the network of tracks and roads. Ben found work in one of the road-contracting gangs working in the Mallee area south of the River Murray. His boss was a German named Brockhoff and it is likely that Ben obtained the job through his German friends on the river. The gang worked on the 'Pinnaroo line' running west through Murrayville in Victoria, and on the road linking Tailem Bend with Karoonda and Alawoona in the centre of the Mallee, finishing near the state border at Renmark. On one occasion this work took Ben to Mildura. After a brief spell there 'looking at the country', he took a leisurely trip back to Waikerie by the river boat 'Jimmy' (See Text J). 
The roadwork was hard, but paid quite well, according to Ben. He began as a labourer and horse teamster but was soon promoted to overseer.

Some were digging, like on the quarry, some on roadwork, spreading stuff...some driving drays, carting it...My job was standing over the mob...I was acting boss you know, when the boss goes away he put me in charge of them all. I had to start them right time, make 'em knock off right time, all that. And see the right thing done on the road. 78

These road crews contained a colourful mixture of people and personalities, something like the cross-section found working on remote oil or gas drilling rigs today. There were a number of Italian people, (some of the early migrants from that country to South Australia), among these road-gangs, as well as ex-servicemen and Aboriginal people. As Text $\mathrm{K}$ relates, relations between the workers were not always smooth. Ben had the power to hire and fire gang members, and used it occasionally: 'If they were too nasty, I put them off. You lose your job, that's alright, you go. ${ }^{79}$

The experience of working in a road gang probably recalled something of the camaraderie Ben had experienced in the war. This sense may have become heightened as the Depression approached and as it did, many working men in country areas sought additional support by joining organisations such as the Royal Ancient Order of Buffaloes (R.A.O.B.). An R.A.O.B. Lodge was established at Alawoona in 1927 and Ben joined in March of the following year. He still wears the badge today. According to Ben, a large proportion of the road workers became members:

I joined that Buffalo...They reckoned you'd get more jobs if you joined up.

You'd make a road, stretch of road, might be thirty mile, forty mile, you knock off then. You'd have to wait till another contract come in. They'd have a meeting and they say, 'You can get a job...put you on another job' ${ }^{80}$

It was in the Mallee country that Ben met his sister Shirley again, by sheer chance after many years separation. His sister had married a man named Hirsch and Ben met her two sons at a football match at Paruna:

I ran into the two boys...I was watching the football... One of the boys said, 'Come over there, mum wants to see you [they said], you might know her'. I couldn't make out whose kids...calling me uncle! When I got over there...my sister starts talking the lingo, I know her then! 'Oh, sister! [I said] What are you doing here?' 'I been away a long time', she said. 'I got two sons and a daughter'...She went to the football to have a look. ${ }^{81}$

\section{Text K 'Dr Murray'}

Recorded by Peter Austin at Cooper Creek 27th June 1976 (fieldtape D37a, transcription Book IV pp 53-55)

When Ben was working at Murrayville in Western Victoria building roads there occurred an incident which demonstrates perfectly his willingness to help those in need and to take action when he believed that an injustice had been done. Looking back on the incident, Ben recalled that the woman involved called him Dr Murray' after the event.

81 M-J, 2.2.88.

81 M-J, 9.1.88. 


\section{BEN MURRAY}

$\begin{array}{llll}\text { 1. Ngathu } & \text { nganka-rda } & \text { purrhi-ya } & \text { palthu-nhi. } \\ \text { I-ERG } & \text { work-PTCPLE } & \text { AUX-PAST } & \text { road-LOC }\end{array}$

2. Nganhi mayatha ngana-rnda purrhi-rnda palthu-nhi I boss be-PTCPLE AUX-PTCPLE road-LOC

palthu nganka-rda purrhi-rnda.

road make-PTCPLE AUX-REL SS

3. Matharri nhulu nhaka nganka-rda purrhi-yi nhaka man he-ERG there work-PTCPLE AUX-PRES there

nhuwa-ntha-li.

spouse-PROP-ERG

4. Nhani mandranju ngana-yi ngana-mda purrhi-rnda. she pregnant be-PRES be-PTCPLE AUX-PTCPLE

5. Nhandrru nganja-yi kupa darnka-rda purrhi-lhali. she want-PRES child bear-PTCPLE AUX-IMPL SS

6. Wata nhulu pardaka-mida purrhi-yi ya wata nhawu ngakangu not he-ERG take-PTCPLE AUX-PRES and not he me-LOC

yatha-rnda purrhi-rnda nhandrru nganja-yi kupa darnka-rda talk-PTCPLE AUX-PTCPLE she want-PRES child bear-PTCPLE

purrhi-lhali.

AUX-IMPL SS

7. Karna parlpa wakara-rnda purrhi-yi Italian. man some come-PTCPLE AUX-PRES

8. 'Ben, signorina very sick.

9. Wilha nhani-ya munja parrharnda purrhi-yi.' woman she-here ill lie-PTCPLE AUX-PRES

10. 'Minha?'

what

11. 'Aa, kupa nganja-yi darnka-rda purrhi-lha.'

Oh child want-pPRES bear-PTCPLE AUX-IMPL SS

12. 'Tell the man to help her. You know what to do.

13. Yini yatha-rnda purrhi-ya-mayi nhulu nhinha kupa you say-PTCPLE AUX-IMPER-EMPH he-erg him-acc child 
ABORIGINAL HISTORY 1988 12:2

thardupa-mda thika-rndanhi.'

push-PTCPLE return-REL DS

14. He go back and told him alright. He never took a notice. He just sat there.

15. Nhani nhungkangu yatha-rnda purrhi-rnda You do this. she him LOC say-PTCPLE AUX-PTCPLE

16. Yaruka nganka-mayi.'

like that do-IMPER-EMPH

17. Wilha yatha-rnda purrhi-yi 'Yini karka-rnda woman say-PTCPLE AUX-PRES you call-PTCPLE

purhi-ya-mayi mayatha nhinha Mr Murray get him over here' AUX-IMPER-EMPH boss him-ACC

18. Nganhi wapa-rna.

I go-PTCPLE

19. 'Can you do me a favour?'

20. Yundrru nganja-yi nganha maranguka-mda purrhi-lhali? you-ERG want-PRES me-ACC help-PTCPLE AUX-IMPL SS

21. Windrri kupa nhinha-ya thardupa-rnda thika-mayi. only child him-ACC-this push-PTCPLE return-IMPER-EMPH

22. Nhawu-ya marnka durnka-rda purrhi-yi.' he-this slowly emerge-PTCPLE AUX-PRES

23. I didn't want to do it.

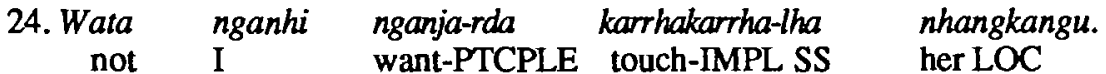

25. She had the dish of lye water. I had to wash my hands.

26. Nganhi mara kurlirka-tharrhi-rnda purrhi-rnda. I hand clean-REFL-PTCPLE AUX-RELSS

$\begin{array}{llll}\text { 27. Ngarda-nhi } & \text { nhinha } & \text { kupa-kupa mangathandrra thardupa-mida } \\ \text { then-LOC } & \text { him-ACC child-child head } & \text { push-PTCPLE }\end{array}$

thika-rnda purrhi-yi thalku-nganka-rda purrhi-rnda.

return-PTCPLE AUX-PRES straight-TRVB-PTCPLE AUX-REL SS

28. Ngathu yakalka-rnda "Wardaru yanika?"

I-ERG ask-PTCPLE how like this 
BEN MURRAY

29. 'Ngalyi marla karrji-lka-rnda purrhi-ya-mayi.'

a little more turn-TRANS-PTCPLE AUX-IMPER-EMPH

30. Hard to tell exactly, you know, how they feel it in there.

31. 'Maja nhawu-parrha-wu!'

OK he-DEF-EXCLAM

32. Tharrka-rnda purrhi-rnda. stand-PTCPLE AUX-PTCPLE

33. 'Nganhi tharka-rnda purrhi-rnanhi and he'll just slip out.' I stand-PTCPLE AUX-REL DS

34. Yeah, nhawu durnki-nga-yi kupa-kupa puri-rnda purrhi-rnda. he emerge-going-PRES child-child fall-PTCPLE AUX-REL SS

35. 'Alright Mr Murray, ngathu muntha-lha nganka-rda purrhi-yi."' I-ERG self-NI do-PTCPLE AUX-PRES

36. She started cleaning it. She must be a strong woman, by cripes. I hit him then, I couldn't help it.

$\begin{array}{clllll}\text { 37. Ngathu } & \text { nhinha } & \text { karna } & \text { marna } & \text { nhungkarni } & \text { daka-mda } \\ \text { I-ERG } & \text { him-ACC } & \text { man } & \text { mouth } & \text { his } & \text { hit-PTCPLE }\end{array}$ purrhi-yi..

AUX-PRES

38. 'Minha-ndrru yundrru wata manyu-yali nhayi-rnda purrhi-yi?' what-AB; you-ERG not good-ERG look-PTCPLE AUX-PRES

39. 'Yundrru maranguka-rnda purrhi-yi.' you-ERG help-PTCPLE AUX-PRES

40. Bang, I hit him.

41. Nganhi yatha-rnda purrhi-yi Wilha wata yini nhungkangu I say-PTCPLE AUX-PRES woman not you him LOC

ngama-rnda purrhi-rnda warara-mda purrhi-ya-macyi!

live-PTCPLE AUX-REL SS leave-PTCPLE AUX-IMPER-EMPH

42. You'll die. Yini pali-rnda purrhi-lha nganayi. you die-PTCPLE AUX-FUT AUX

$\begin{array}{cllll}\text { 43. Nhawu-ya } & \text { ngama-rnda } & \text { purrhi-rnanhi } & \text { yinha } & \text { nhayi-rnda } \\ \text { he-this } & \text { sit-PTCPLE } & \text { AUX-REL DS } & \text { you-ACC } & \text { look-PTCPLE }\end{array}$ 
purrhi-rnda.

AUX-REL SS

44. You know how they feel, you know.
45. Kajakaja-rnda
marrji-mda
purrhi-rnda
yindrrarda
be in pain-PTCPLE
cry out-PTCPLE
AUX-REL SS
cry-PTCPLE

purrhi-rnda.

AUX-REL SS

46. Woman, you know, with a pain, and he's sitting there like a dog. Christ, made me wild.

\section{Ngathu nhinha nandrarda purrhi-yi. \\ I-ERG him-ACC hit-PTCPLE AUX-PRES}

48. Yeah, that's the story.

\section{Translation}

1. I was working on the roads.

2. I was the boss of the roads, building roads.

3. A man he was working there with his wife.

4. She was pregnant.

5. She was about to have a child.

6. He didn't take her and he didn't tell me that she was about to have a child.

7. Someone came along, an Italian.

8. (He said:) 'Ben, signorina very sick.'

9. The woman she's sick.

10. 'What?' (I said)

11. 'Oh, she is about to have a child.'

12. 'Tell the man to help her, you know what to do.'

13. 'You tell (him) he is to push the child back.'

14. He go back and told him alright. He never took a notice. He just sat there.

15. She said to him 'You do this'.

16. 'Do this.'

17. The woman said 'You call the boss Mr Murray, get him over here'.

18. I went.

19. (She asked) 'Can you do me a favour?'

20. 'Would you like to help me?

21. Just push the child back.

22. He will come out slowly.'

23. I didn't want to do it.

24. I didn't want to touch her.

25 . She had the dish of lye water. I had to wash my hands.

26. I cleaned my hands.

27. Then I pushed the child's head back, straightening him.

28. I asked 'How is that?'

29. 'Turn him a little more' (she said).

30. Hard to tell exactly, you know, how they feel it in there. 
31. That's it!"

32. I stood up.

33. 'When I stand up and he'll just slip out' (she said).

34. Yeah, he came out past me, the child fell out.

35. 'Alright Mr Murray, I'll do it myself.'

36. She started cleaning it. She must be a strong woman, by cripes. I hit him then, I couldn't help it.

37. I hit the man in his mouth.

38. 'Why didn't you look after (her) properly?'

39. 'You helped her' (he said).

40. Bang, I hit him.

41. I said 'Woman, don't stay with him, leave him!

42. You'll die. You will die.

43. He stayed looking at you.'

44. You know how they feel, you know.

45. She called out in pain and cried.

46. Woman, you know, with a pain, and he's sitting there like a dog. Christ, it made me wild.

47. I hit him.

48. Yeah, that's the story.

After making the road from Karoonda to Cobera and Alawoona, Ben's gang moved to Malpas and then Paruna where they were based for some months, before turning north to the Murray River and meeting it at Paringa. Ben left the gang there and returned to Lowbank, to stay with his old friend Jack Rohrlach. This was probably some time during 1930.

At Lowbank he met another old school friend from Killalpaninna, Helen Jericho (formerly Vogelsang). She was visiting from her home at Kadina at the top of Yorke Peninsula, and urged Ben to come over there to work on her husband's farm. He agreed and within a few weeks was ploughing the fields and driving a header - this time on a tractor, rather than a horse:

I got on alright [after] a while. Not too good for a start. Anyhow I had to work the ground, one way first then across again...put the seed in, and go and cut hay... all that machine work. ${ }^{82}$

After working for the Jerichos Ben moved to a neighbouring farm at Moonta, this time to work for a less sympathetic employer (see text below). This man was heavily mortgaged to the State Bank and obviously considered that he could get by without paying Ben sufficiently or allowing him basic conditions. Ben thought otherwise and gave notice. He had decided to retum to his own country in the far north of South Australia.

\section{Text L 'The Farmer'}

Recorded by Peter Austin at Pantupirna, 30th June 1976 (fieldtape D38a, transcription Book IV pp 74-5)

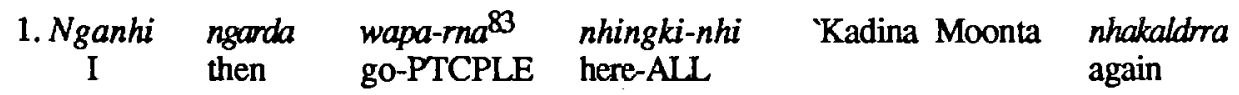


ABORIGINAL HISTORY 1988 12:2

farm-anhi mitha paku-ma puka thandra kurrha-lha.

farm-LOC ground dig-REL SS plant seed put-IMPL SS

2. Ngarda-nhi wintha puka thandrra manyu-rri-rnanhi ngathu then-LOC when plant seed good-INCHOAT-REL DS I-ERG

minha-li-ya pirta-li wakarri-pa-ma wanthiyi.

what-ERG-IGNOR stick-ERG break-TRANS-PTCPLE AUX

3. Reaping then, nyurri-rna like cleaning it, 1933, last job I had, husk-[TC $[; \mathrm{E}$

me and Billy Lamb.

4. Ngali nganka-rda purrhi-yi ngali Billy Lamb, we two EXCL work-PTCPLE AUX-PRES we two EXCL

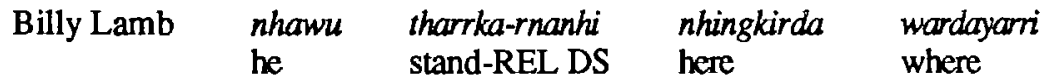

thana puka thandrra payiku nhulu kurrha-yi

they plant seed bag he-ERG put-PRES

five bags each round, half way.

5. Tharrka-yi nhaka thana-nha pirirri-nganka-rna. stand-PRES there them-ACC full-TRVB-REL SS

$\begin{array}{lll}\text { 6. } Y a & \text { nhakaldra } & \text { karnj-rna } \\ \text { and again } & \text { turn-PTCPLE }\end{array}$ another five $\begin{aligned} & \text { yaruka-ldrra-matha } \\ & \text { like that-ADD-IDENT }\end{aligned}$

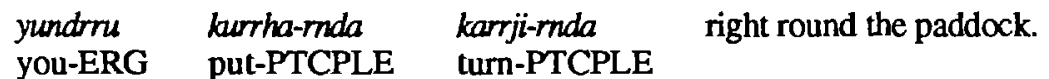

7. Yaruka nganka-rda kurnu nhingkirda kurnu yarlaga like that work-PTCPLE one here one elsewhere

kurnu nhingkirda yaruka every five.

one here like that

8. Ngarda-nhi nhakaldrra karrji-yi another five. then-LOC again turn-PRES

9. Nhakaldrra kurrha-rnda thika-yi mara warrha ${ }^{84}$ again put-PTCPLE return-PRES hand half

84 This is another example of counting in Diyari-Thirrari (see footnote in Text H). 
murda-lha-rlu.

finish-IMPL SS-still

$\begin{array}{clll}\begin{array}{c}\text { 10. Ngarda-nhi } \\ \text { then-LOC }\end{array} & \begin{array}{l}\text { nhawu farmer } \\ \text { he }\end{array} & \begin{array}{l}\text { wakara-yi } \\ \text { come-PRES }\end{array} & \begin{array}{l}\text { ngalirni } \\ \text { our two EXCLDAT }\end{array}\end{array}$ $\begin{array}{lllll}\text { pardaka-yirrpa-rna } & \text { puka } & \text { thayi-rnanthu } & \text { diji } & \text { thati. } \\ \text { carry-ALT-REL SS food } & \text { eat-IMPLDS } & \text { day } & \text { middle }\end{array}$
11. Ngali thayi-yi. we two EXCL eat-PRES

12. Ngarda-nhi five minutes 'Better get going.' then-LOC

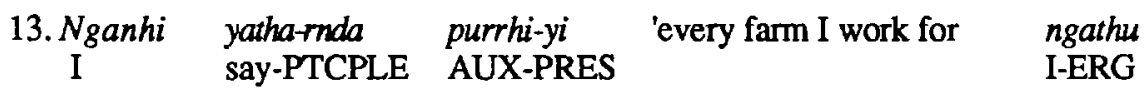
nganka-ya hour for dinner.' work-PAST
14. Nhawu
muntha-rlu he self-still
kari-rna thara-yi. climb-PTCPLE go up-[RES 15. Ngarda-nhi
then-;PC $\begin{array}{llc}\text { nganhi } & \text { yatha-yi } & \text { wata } \\ \text { I } & \text { say-PRES } & \text { not }\end{array}$ mindrri-ya nhungkangu. run-IMPER him LOC

16. Warrara-mayi leave-IMPER-EMPH he

$$
\text { nhawu karrii-rnanthu. }
$$
turn-IMPL DS

17. Ngaldrra karlka-yi we two INCL wait-PRES nhawu karrji-rnanhi he nhingkirda-nhi

nhakaldra again

$$
\text { thika-lha }
$$
return-IMPL SS

18. Marlarlu truly nhaw he

muntha
self

19. Nhawu he thika-yi. return-PRES

20. 'I thought you blokes gonna run after me.'

21. 'I never chased a boss in my life.
22. Wata ngathu mayatha ngakarni yaruka karri-rna wanthi not boss my karrji-yi. turn-PRES here-ALL 
ABORIGINAL HISTORY 1988 12:2

$\begin{array}{llllll}\text { ya } & \text { wata } & \text { ngathu } & \text { yinha } & \text { karri-lha } & \text { nganayi.' } \\ \text { and } & \text { not } & \text { I-ERG } & \text { you-ACC } & \text { chase-FUT } & \text { AUX }\end{array}$

$\begin{array}{clll}\text { 23. Nhawu-ya } & \text { ngakarni } & \text { murda-ni } & \text { nganka-ni. } \\ \text { he-this } & \text { my } & \text { finish-NOMIN } & \text { work-NOMIN }\end{array}$

24. Nhingkirda-ndrru nhinha ngathu murda-rna nganhi here-ABL

him-ACC I-ERG finish-REL SS I

$\begin{array}{lll}\text { thika-rnda } & \text { purrhi-lha } & \text { nganayi.' } \\ \text { return-PTCPLE } & \text { AUX-FUT } & \text { AUX }\end{array}$

$\begin{array}{clll}\text { 25. Wardayarri } & \text { yini } & \text { thika-lha } & \text { nganayi?' } \\ \text { where } & \text { you } & \text { retum-FUT } & \text { AUX }\end{array}$

$\begin{array}{clllll}\text { 26. Nganhi } & \text { thika-lha } & \text { nganayi } & \text { wardayarri-ndru } & \text { nganhi } & \text { wakara-ya. } \\ \text { I } & \text { retum-FUT } & \text { AUX } & \text { where-ABL } & \text { I } & \text { come-PAST }\end{array}$

27. Kudnankarri-lha nganhi thika-lha nganayi $\begin{array}{llll}\text { south-NI I } & \text { return-FUT }\end{array}$

$\begin{array}{clll}\begin{array}{c}\text { 28. Kudnankarra-ndrru } \\ \text { south-ABL }\end{array} & \text { nganhi } & \text { thika-yi } & \text { thidnankarra-lha.' } \\ \text { I } & \text { retum-PRES } & \text { north-NI }\end{array}$

29. 'Where you gonna go?'

30. 'You know where I'll go. North, where I came from.'

Translation

1. Then I went here to Kadina (and) Moonta again, on a farm, digging the ground and planting seeds.

2. Then when the seeds are good I broke them with a what's-it, stick.

3. Reaping then, husking, like cleaning it, 1933, last job I had, me and Billy Lamb.

4. We worked, Billy Lamb and I, Billy Lamb he would stand here where the seed bags are, he'd put on five bags each round, half way.

5. He'd stand there filling them.

6. And turn again, another five just like that, you put them in as you turn, right round the paddock.

7. We worked like that, one here, one over there, one here, like that, every five.

8. Then go round again, another five.

9. Put back five again until you finish.

10. Then the farmer came carrying our dinner so we could eat at midday.

11. We ate.

12. Then after five minutes [he said] 'Better get going.'

13. I said 'every farm I work for I had an hour for dinner.'

14. He climbed up himself.

15. Then I said [to Billy Lamb] 'don't run after him.

16. Leave it until he comes round.

17. We'll wait for him to come round to here again and come back.'

18. He really went round by himself. 


\section{BEN MURRAY}

19. He came back.

20. 'T thought you blokes gonna run after me.'

21. 'I never chased a boss in my life.

22. I have never chased my boss like that and I won't chase you.'

23. That was my last job.

24. 'When I finish it from here l'll go back.'

25 . 'Where will you go back to?'

26. 'I'll go back to where I came from.

27. I'll go back south [to Adelaide].

28. From the south I'll go back north.'

29. 'Wtere you gonna go?'

30. 'You know where I'll go. North, where I came from.'

\section{4: North, 'Where I Came From'}

Instead of making his way north immediately, Ben first caught the train to Adelaide. His mcther's old employer, Mrs Murray, had moved her business to the city from Marree and Ben stayed at her boarding house on North Terrace. He spent a few days seeing the sights and 'having a bit of a sit down', before making his next move. Apart from Mrs Murray Ben knew at least one person in Adelaide, Helen Jericho's brother Ted Vogelsang, grandson of Hermann Heinrich Vogelsang, the patriarch of Killalpaninna mission. Teddy Vogelsang was employed as an attendant at the Adelaide Museum. Here he worked, between his other tasks, at translating the fourteen volume manuscript describing the life and beliefs of the Diyari Aborigines which had been prepared by Pastor Reuther of Killalpaninna between 1888 and 1906.85

Ben assisted in the translation and remembers seeing the remarkable ethnographic collection gathered by Reuther which was on display in the Stirling Gallery, including the toas. He met the ethnologist Norman Tindale ('Tintail' as Ben remembers him) and recalls discussing the respective veracity of Vogelsang's translation and that offered by George Aiston, the ex-policeman and Birdsville Track storekeeper who had criticised the Lutherans' ethnographic work. ${ }^{86}$ The fact that Ben was literate in both English and Diyari put him in a unique position to judge the translations. Ben was heavily in favour of Vogelsang's work:

How would he [Aiston] know? He reckoned he born amongst them. I said: No, he's a police sergeant!'. All the Diyari lingo, he altered them....altered this, altered that, said this not right, that not right...I went there, that Museum, and I saw the other bloke [Tindale]. I said: Now, that's not wrong. Vogelsang was born and reared amongst the blacks. He knows the words'...He [Tindale] said: 'We got both words here [i.e. Vogelsang's and Aiston's], but me didn't know if Aiston's was the truth'...I said: 'Because he was a policeman you took his word!'87

While in Adelaide, Ben met up with Mick McLean, a Wangkangurru man related to his stepfather who was employed in the police force as a black tracker. Ben accompanied Mick one day to the wholesale markets where he participated in the apprehension of a chicken thief. He was impressed by the two young police detectives he met there called Barrington and Beek: 'Young policemen, plainclothes, they knocks about. They don't say much but,

85 Rejther 1981.

86 Jones and Sutton 1986:54-61; Horne and Aiston 1924:26.

87 M-J, 29.7.83; June 1985. 
by cripes, they know a lot though. ${ }^{88}$ However, Ben had made up his mind to return to his country in the North, and typically, took the opportunity in Adelaide to arrange a position for himself before leaving. This time, instead of relying on his contacts in the German community, Ben went to see his first employer, the 'Cattle King' Sir Sidney Kidman, at his office in the city. Kidman, by now an old man, was willing to give Ben a job at Witchelina station and sent him to see his son-in-law, Sidney Reid, to arrange the details. Ben tells the story:

I went to Sidney Kidman, old feller was still alive then. 'Oh [I said], I was looking for a job' [Kidman replied:] 'Oh, you go back, go up north, to Witchelina'. Alright, I went the next morning, I went to Sidney Reid. 'The boss [Kidman] sends me, to see about a job.' 'Oh [said Reid], I don't know you much, you can't get a job. No job: 89

Ben's reaction to this setback was typical. Rather than become intimidated by Kidman's son-in-law, he decided to offer his services to someone of equal stature:

'That's alright, I'll go and see Bart Smith'...[Bart Smith said:] 'You can go to Murnpeowie, I'll give you the fare - do you want a fare?' 'Yes [said Ben], I'll give it back to you, as soon as I get a job'. 'Oh, there's a job there [said Barr Smith], on the border netting. You've got to ride the border netting'. 90

Ben went away satisfied, and prepared for the trip north to Marree. In the meantime, Kidman must have heard of the treatment which Ben had received from his son-in-law and 'jumped on his neck', ordering him to give Ben a job:

Next moming, Sydney Reid sent a man around, [saying:] 'I cancelled that job for you [i.e. reserved a job for you]'. 'No [said Ben], I wasn't good enough yesterday, I'm not good enough to go back there now...Old gentleman Barr Smith give me a job... Me and you never agree. You knock me back in the first place - you knew me from a little kid, those girls too [Edna and Blanche Kidman]'. They used to help me on the horse and tie me down and all that, that's where I learnt to ride the old horse. ${ }^{91}$

Ben refused Reid's offer and after taking the train to Marree and the mail truck north to Murnpeowie, met the manager:

Mr Lou Newland, he was managing. 'Oh', he said, 'Who sent you here?' 'Barr Smith, [he gave me] job on the netting' [I said]. 'Oh, we better wait until the netting boys come along' [Newland said]. Stan Watkins, he come over, he give me the job - 'You come with us'. Him and his brother [Ben Watkins], they was on the netting... They give me camels then, couple of camels [four in fact]. [They] give me a length, how far I got to travel, till I meet somebody else, another netting rider, and turn back again. You got to clean everything along the netting, shovel sand away, put the netting up again.

Buried, some of the netting, buried...Hard work, yeah. 92

Ben was sometimes away for two or three months at a time, patrolling his sector of the fence on the eastern boundary of the station, before returning to the head-station for a fresh

88 Comments on a Diyari text recorded by Peter Austin, Canberra 10 February 1977 (field tape D47b, transcription Book IV p.140).

M-J, 29.7.83.

90 M-J, 29.7.83.

91 M-J, 29.7.83.

92 M-J, 14.3.87. 


\section{BEN MURRAY}

supply of rations. He worked south from Murnpeowie Creek to 'Donkey Corner' at the bottom end of the netting: 'I was on me own...I had four camels...carry some posts, carry some netting, one to carry water, one to ride'.93 After the Watkins brothers left, Ben's cousin Gottlieb Merrick worked sections of the fence to the north, with his wife Frieda and daughters Susie (with her husband Rudi Kennedy) and Gertie (with her husband Jimmy Sweeney).

The days of camel trains in the north were over by this time and the old 'wool road' south from Cordillo Downs through Murnpeowie, Donkey Comer (on the netting fence) and Blanchewater to the railway at Farina was falling into disuse. The wool load was now carted by wagons and the first motorised trucks. Nevertheless, Ben occupied his time at the head-station between boundary riding forays by making camel saddles for his own use and for the others patrolling the fence.

Gottlieb Merrick became ill while working on the netting fence in about 1940. Ben tried to get him back to the head station at Murnpeowie but it was too late. Gottlieb died soon after and Ben and Gottlieb's sons-in-law buried him at Dingo Waterhole. With Gottlieb's death his family moved away from the station and Ben decided to go as well.

\section{A holiday in the Top End}

With no immediate family to support Ben had accumulated some savings from his work on the netting fence. After leaving Murnpeowie he took the opportunity to see parts of Australia which he had never visited and was unlikely to see again. He began by catching the train to Alice Springs. From there he travelled at least part of the way to Darwin by motor car with two other (white) friends whom he met in the Centre - one of whom was a Queenslander named Jack Reid. The Japanese had bombed ('king-hit') Darwin by this time, and as Ben puts it: 'General MacArthur took it over then...chasing the Japanese. He did too - he soon made a mess of them'.94

Ben spent some time in Darwin before taking a steamer with a friend along the coast of north Australia to Thursday Island in the Torres Strait. This was apparently a free trip, given in exchange to Ben and a friend for bringing a mob of horses to Darwin from Alice Springs, probably at about the same time.

When asked what he did on Thursday Island, and in Darwin, Ben's reply is short, if laconic: 'Just to have a look, that's all, went to have a look at the country'. ${ }^{55}$ As a single man of independent means Ben would have been an attractive proposition for many of the girls he met on his travels but he remained unattached. In his earlier years Ben was not interested in marriage:

That time I didn't worry about any girl. I wanted to have a look around, have a good look around. Woman didn't worry me.

During the 1930s, when he was working near the River Murray, Ben had become very friendly with a white girl from New South Wales named Alice McArthur. She was a nurse at the Loxton Hospital and was later killed by the Japanese during the early stages of World War II. Ben's bachelorhood was perhaps the price he paid for his free and independent life. As he puts it:

\footnotetext{
93 M-J, 9.1.88.

94 M-J, 2.2.88.

95 M-J, 2.2.88.
} 


\section{ABORIGINAL HISTORY 1988 12:2}

I never had the chance to pick up a girl. I been travelling around...too busy. I met a girl - I went to Thursday Island, that island other side, Brisbane. ${ }^{96}$ I went there, 'Come on, [she said] please take me home, take me back, please!' No, I'm too busy'. I went to Darwin, the same. Alice Springs - there was a mob of girls there....Everywhere I went, 'take me home, take me home'...I never hooked any of them.97

Ben took his time returning from Darwin, visiting the Aboriginal mission at Katherine, and travelling by horse through the north of Western Australia. Here he saw bush Aboriginal people - 'naked, walking around' - and met Chinese people for the first time: 'Chinamen breed...I give them a chance, couldn't understand what they were talking: $98 \mathrm{He}$ and his friends reached Alice Springs, where they stayed for a while, attending a rodeo:

we went to turnout there, buckjump, roughhorse show...And a girl...I forget the girl's name - she was riding a horse there, from Queensland! Queensland girl, she beat the lot of them. 99

After all this excitement, Ben finally retumed to South Australia and another job on the netting fence at Murnpeowie station.

\section{0s - 1960s: Station work}

In about 1948 the netting fence finally lost its battle with the drifting sand and it was taken down. 'They didn't want any more netting rider', Ben said. A new manager had been appointed to the station at this time and without consulting or recompensing him, shot Ben's camels and horses. Ben left in disgust. This man was, as Ben puts it, a rubbish manager...'he didn't last long anyway'. Ben returned to Murnpeowie for a while when a new manager was appointed, and found three camels which had belonged to a man who had perished on the Strezlecki Track not long before:

Young feller called Shaw...all the Afghans went up there, trying to find him they give it up. He's out there somewhere. ${ }^{100}$

With the netting work finished, Ben's skills as a horseman were enlisted to hunt down the dingoes which now had easier access to Murnpeowie. He was paid five shillings for most scalps, and ten shillings for those dingoes which the other station men were unable to catch. He rarely missed his quarry:

It was a lot of work. You got to track him down, hard to see the track in the hilly country. I used to come to the water, where he used to come in and get a drink. Wait for him there...I had a rifle, had a good horse too...He come in and have a drink, went out again. I'd see the way he went out, get the horse, went after him. I see him on the flat. I after him, I chase him, ride him down. Get up right alongside of the dog...aim just in front of the dog, and I hit him. I get the dog, go back [to the station]. 'I got the dog, he look the

96 Thursday Island is of course a great distance from the city of Brisbane; the reference here is probably to the fact that it is in the state of Queensland of which Brisbane is the capital.

M-J, 2.2.88.

98 M-J, 31.7.87.

99 M-J, 31.7.87.

100 M-J, 9.1.88. 


\section{BEN MURRAY}

same as what you said [Ben said to the manager]'. I show him the skin. 'Alright'. 101

Ben finally left Murnpeowie and went west to Mundowdna, a Kidman property, where he cut fence-posts ('a thousand') with his old camel driving partner from Killalpaninna, Jack Hanness. Other station work followed, and filled the years from the 1950 s through into the 1960s. After Mundowdna, his next job was fencing, on another Kidman property to the south at Witchelina from 1950 , followed by stockwork, horse-breaking and dingo-tracking on Myrtle Springs, the station adjoining. Here he worked for Smith and Sons - 'champion people'.

TEXT M 'Making dingo baits'

Recorded by Peter Austin at Farina 11th January 1975 (fieldtape D15a, transcription Book II $\mathrm{p}$ 4).

While making dingo baits on Myrtle Springs Ben was bitten by a poisonous snake. Quick thinking saved his life.

$\begin{array}{llccc}\begin{array}{l}\text { 1. Nganhi } \\ \text { I }\end{array} & \begin{array}{l}\text { ngama-rnda } \\ \text { sit-PTCPLE }\end{array} & \begin{array}{l}\text { purhi-rnda } \\ \text { AUX-PTCPLE }\end{array} & \begin{array}{l}\text { juju } 102 \\ \text { danger }\end{array} & \begin{array}{l}\text { nganka-rda } \\ \text { make-PTCPLE }\end{array} \\ \text { purrhi-rnda } & \text { kinthala } & \text { yampa } & \text { nganthi } & \text { yingki-rda } \\ \text { AUX-REL SS } & \operatorname{dog} & \text { wild } & \text { meat } & \text { give }\end{array}$

purrhi-lhali

AUX-IMPL SS

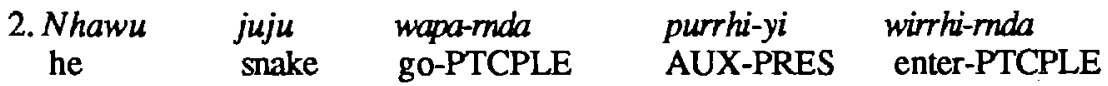

parlka-rnda

go along-REL SS bag-LOC

ngama-mada purrhi-lhali.

stop-PTCPLE AUX-IMPL SS

\section{Nganhi} I

\section{murda-rnda}

purrhi-yi

juju

nganka-rda purrhi-mda

finish-PTCPLE AUX-PRES bait make-PTCPLE AUX-REL SS

\section{Ngathu}

yanuka

nhinha

malthu

mani-mda purrhi-yi

I

like that

him

bag

get-PTCPLE AUX-PRES

5. Nganhi

\section{ngara-tharrhi-yi}

matha-rnda

purrhi-yani

parruma-rnda

I

hear-REFLEX-PRES

bite-PTCPLE AUX-IMPL DS pull-PTCPLE

purrhi-rndanhi

AUX-REL DS

$\begin{array}{cll}\text { 6. Nhayi-rnda } & \text { wanku } & \text { wakara-manhi } \\ \text { see-PTCPLE } & \begin{array}{l}\text { snake } \\ \text { come-REL DS }\end{array}\end{array}$

101 M-J, 9.1.88.

102 The term juju is normally used to refer to dangerous insects and reptiles (see line 2). Here Ben has extended its meaning to cover the sense of poison baits. 
ABORIGINAL HISTORY 1988 12:2

$\begin{array}{clllll}\text { 7. Ngathu } & \text { nhinha } & \text { thidna } & \text { mandra-ni } 103 & \text { mani-rnda } & \text { purrhi-yi } \\ \text { I } & \text { him } & \text { foot } & \text { grasp-NOMIN } & \text { get-PTCPLE } & \text { AUX-PRES }\end{array}$

8. Nhinha thuku wakaripa-rnda purrhi-yi him back break-PTCPLE AUX-PRES

9. Thika-yi ngakarni nhayipa mani-rnda purrhi-yi return-PRES my knife get-PTCPLE AUX-PRES

10. Mara dama-mda purrhi-yi nhayipa-li nguna karrha-rnda. hand cut-PTCPLE AUX-PRES knife am tie-PTCPLE

$\begin{array}{lllll}\text { purrhi-rnda } & \text { mara } & \text { pakarnda } & \text { kumarrhi } & \text { ngaka-mda } \\ \text { AUX-REL SS } & \text { hand } & \text { also } & \text { blood } & \text { flow-PTCPLE }\end{array}$

purrhi-yani .

AUX-IMPL DS

$\begin{array}{cccll}\text { 11.Ngathu thana-nha juju } & \text { warra-ma } \\ \text { I } & \text { they-ACC bait throw-PTCPLE } & \begin{array}{l}\text { purrhi-yi } \\ \text { AUX-PRES }\end{array} & \text { thidna } \\ \text { foot }\end{array}$ mandrra-ni kurrha-rnda purrhi-rnda.

grasp-NOMIN put-PTCPLE AUX-REL SS

$\begin{array}{lllll}\text { 12. Yaruka mara } & \text { kurrha-yi } & \text { windrri kumarrhi } & \text { ngaka-rnda } \\ \text { like that hand put-PRES } & \text { only blood } & \text { flow-PTCPLE }\end{array}$

urrhi-yani.

AUX-IMPL DS

13. Wanku snake

nhawe

he

ngurrha-li

always-ERG

14. Ngathu

I

nhink

him japuli

shovel walki-rnda move-PTCPLE purrhi-yi .

AUX-PRES

mani-rnda purrhi-yi thika-lka-rnda

get-PTCPLE AUX-PRES retum-TRVB-PTCPLE

handle payirrhi-nths

handle long-COMIT

15. Thurrhu nhinha ngathu piri-nganka-rda purrhi-yi thati fire him I space-CAUS-PTCPLE AUX-PRES middle

nhinha wara-mada purrhi-lhali.

him throw-PTCPLE AUX-IMPL SS

103 Ben describes the dingo trap as thidna mandrrani, literally 'foot grasper'. 


\section{BEN MURRAY}

$\begin{array}{lllll}\text { 16. 'Ngathu } & \text { yinha } & \text { kurrha-rnda } & \text { purrhi-yi } & \text { nhingkiya } \\ \text { I } & \text { you-ACC } & \text { put-PTCPLE } & \text { AUX-PRES hu-nhi } \\ & \text { here } & \text { fire-LOC }\end{array}$

$\begin{array}{lll}\text { yidni } & \text { pali-rnda } & \text { purrhi-yani : } \\ \text { you } & \text { die-PTCPLE } & \text { AUX-IMPL DS }\end{array}$

$\begin{array}{lllll}\text { 17. 'Nganhi pali-rnda } & \text { purrhi-yathi } & \text { karrari } & \text { thinka-nhi. } \\ \text { I } & \text { die-PTCPLE } & \text { AUX-might } & \text { today } & \text { night-LOC }\end{array}$

$\begin{array}{llllll}\text { 18. Kawu. } & \text { Ngathu } & \text { nhinha jam tin } & \text { thurrhu-nhi } & \text { kurrha-yi } \\ \text { Yes } & \text { I } & \text { him } & & \text { fire-LOC } & \text { put-PRES }\end{array}$

thurrhuthurrhu-nganka-rna.

hot-CAUS-REL SS

\begin{tabular}{|c|c|c|c|}
\hline $\begin{array}{l}\text { Ngarda-nhi } \\
\text { then-LOC }\end{array}$ & & $\begin{array}{l}\text { winma-rnda } \\
\text { put in-PTCPLE }\end{array}$ & \\
\hline
\end{tabular}

dukaramda purrhi-rndanhi.

take off-PTCPLE AUX-REL DS

$\begin{array}{cllllll}\text { 20.Dapa } & \text { ngana-rna } & \text { wanthiyi } & \text { pira } & \text { kurnu, pira larnu } \\ \text { sore } & \text { be-PTCPLE } & \text { AUX } & \text { moon } & \text { one } & \text { moon }\end{array}$

$\begin{array}{lll}\text { dapa } & \text { ngana-mda } & \text { purrhi-mda. } \\ \text { sore } & \text { be-PTCPLE } & \text { AUX-REL SS }\end{array}$

\section{Translation}

1. I was there making baits to give meat to the wild dogs.

2. A snake came along and got in the bag.

3. I finished making the baits.

4. I got the bag like this.

5. I felt myself being bitten and something pulling.

6. I saw a snake coming.

7. I got a trap.

8. I broke his back.

9. I went back and got my knife.

10 I cut my hand with the knife and tied the arm, and the hand too so the blood would run out.

11. I threw the baits around and put down the traps.

12. That's how I put my hand just so the blood would come out.

13. The snake was still moving.

14. I got a long shovel with a long handle to take him back.

15. I opened up the fire to throw him in the middle.

16. 'I'll put you here in the fire so you'll die.' (I said to him)

17. 'I might die today or tonight.'

18. Yes. I put a jam tin (full of water) in the fire, making it hot.

19. Then I put my hand in it, and took all the skin off.

20. It was sore for one month, for a month it was sore. 
After the 1967 referendum and subsequent legislation, Aboriginal people became eligible for social security payments. Ben's war-time service had already qualified him for a pension however (two pounds a week, according to Ben), and he relied on this more during the $1960 \mathrm{~s}$ as he began to work at a slower pace. While at Witchelina Ben bought some good horses (one named Walklate, after a nurse at Marree, and another named Daisy, an exracehorse) with his savings and used these to hunt down dingoes for local station people: 'Myrtle Springs used to send for me: "Come and have a look at the dogs [dingoes], they're killing the sheep":

A new manager arrived at Witchelina in 1959 - 'they was changing managers all the time' - and Ben decided to move to nearby Farina, a town which had shrunk during Ben's lifetime from a busy rail and commercial centre with a large Afghan population to little more than a ghost town. When Ben moved there the Pattersons were the only other residents and within a few years he was the only occupant, still active in his 70 s. For a while he lived in an iron house in the main street with his brother Em. Ben would sit on the verandah there with his dog Butch, looking out on the main road which still passed through the town, observing the traffic north or south. Following Em's death in 1968 he moved to the old stone police station in Farina and when the roof blew off a couple of years later he shifted once more to the Pattersons' house. He often had guests staying with him, friends or relatives who arrived by the 'Ghan' train on its weekly run. Ben often used it himself to visit Marree or Port Augusta, in much the same way as city dwellers use buses: 'I might even jump on the rattler and come down', was a favourite saying of his.

\section{TEXT N 'Living in Farina'}

Recorded by Peter Austin at Farina on 20th May 1974 (fieldtape D9, transcription Book I p 98). Here Ben speaks of his life in retirement at Farina.

\begin{tabular}{|c|c|c|c|c|c|}
\hline I & $\begin{array}{l}\text { kurnu } \\
\text { alone }\end{array}$ & $\begin{array}{l}\text { ngama-rnda } \\
\text { live-PTCPLE }\end{array}$ & $\begin{array}{l}\text { purrhi-yi, } \\
\text { AUX-PRES }\end{array}$ & $\begin{array}{l}\text { wata } \\
\text { not }\end{array}$ & $\begin{array}{l}\text { thanangu } \\
\text { them LOC }\end{array}$ \\
\hline $\begin{array}{l}\text { yarlarlu } \\
\text { together }\end{array}$ & \multicolumn{2}{|c|}{$\begin{array}{l}\text { marnchumarncuri-mda } \\
\text { mix with-PTCPLE }\end{array}$} & $\begin{array}{l}\text { purrhi-rnda, } \\
\text { AUX-REL SS }\end{array}$ & $\begin{array}{l}\text { wata } \\
\text { not }\end{array}$ & \\
\hline $\begin{array}{l}\text { parlpa-nhi } \\
\text { some-LOC }\end{array}$ & $\begin{array}{l}\text { yarlarlu } \\
\text { together }\end{array}$ & \multicolumn{2}{|c|}{$\begin{array}{l}\text { marnatumarnduri-rnda } \\
\text { mix with-PTCPLE }\end{array}$} & \multicolumn{2}{|c|}{$\begin{array}{l}\text { purrhi-rnda. } \\
\text { AUX-REL SS }\end{array}$} \\
\hline Nganhi & $\begin{array}{l}\text { wakara-mda } \\
\text { come-PTCPLE }\end{array}$ & $\begin{array}{l}\text { purrhi-yi, } \\
\text { AUX-PR }\end{array}$ & $\begin{array}{l}\text { wapo } \\
\text { go- }\end{array}$ & & NDL \\
\hline
\end{tabular}

karna-ndrnu.

person-ABL

$\begin{array}{cllll}\text { 3.Wata } & \text { nganhi } & \text { walkarrha-li } & \text { ngana-ma } & \text { wapayi. } \\ \text { not } & \text { I } & \text { sad-ERG } & \text { be-PTCPLE } & \text { AUX }\end{array}$

$\begin{array}{cllll}\text { 4. Nganhi } & \text { manyu } & \text { ngama-mda } & \text { purrhi-yi } & \text { kurnukurnu. } \\ \text { I } & \text { good } & \text { live-PTCPLE } & \text { AUX-PRES } & \text { alone }\end{array}$

$\begin{array}{cllll}\text { 5. Karna } & \text { wakara-rnanhi } & \text { ngarda-nhi } & \text { ngayani } & \text { yathayatha-yi. } \\ \text { person } & \text { come-REL DS } & \text { then-LOC } & \text { we PL EXCL } & \text { speak-PRES }\end{array}$




\section{BEN MURRAY}

\section{Nhakaldrra wapa-rnda piurthi-yi again go-PTCPLE AUX-PRES}

\section{Translation}

1. I live alone, not mixing together with the others, not mixing together with other people.

2. I came here and got away from people.

3. I am not lonely living alone.

4. I live well by myself.

5. People come and we talk .

6. Then they go again.

\section{0s-1980: Into retirement}

From the late 1960s Ben began to collaborate with white researchers interested in learning about the languages, anthropology and history of the Lake Eyre region. He recorded a short Thirrari text with Bernhard Schebeck at Witchelina in 1965, ${ }^{104}$ the same year that he met Luise Hercus, and he began recording Arabana-Wangkangurru and DiyariThirrari with her from 1968 (see introduction). In January 1974, Luise introduced Ben to Peter Austin who was just beginning his Diyari language studies.

A horse-riding accident on Witchelina station caused Ben to come south again later in 1974. As Ben tells it, he was given a horse which no-one else on the station would ride because of its temper:

Put me in hospital too...I was riding Witchelina station and no-one could ride that horse, they give it to me. I ride it alright...down the hill, coming down, it start bucking then. It fell, four legs up, up the hill and I'm underneath. I kept hitting him, trying to pull my leg out, keep on moving like that and I did get out. I got out the reins and pull him up that way. Then I got on again, and I went to Witchelina station, manager and all the men were there...they wouldn't ride it themselves, no. Force you to ride it. 105

Ben's active working life was finally over at the age of 83, a milestone which he still recalls with regret. From 1975 onwards, Ben devoted more time to research: he assisted Hal Scheffler with his studies of Diyari kinship, ${ }^{106}$ and worked intensively with Peter Austin and Luise Hercus on Diyari, Thirrari and Wangkangurru. He continued to travel extensively, and accompanied Austin and Hercus on a number of fieldtrips to the north and east of Farina, helping to locate and record important mythological and historical sites for preservation, including such places as Blanchewater, Boocaltaninna, Ditjimingka, and his old camping spots between Marree and the Cooper. In February 1977, Ben flew to Canberra ${ }^{107}$ where he spent two weeks living and working with Peter Austin and Luise Hercus. He took the opportunity to 'look around' a new part of Australia and spent some time, among other business, reliving old memories at the Australian War Memorial.

104 A copy of the fieldtape is held in the archives of the Australian Institute of Aboriginal Studies (number A640). We are grateful to Bernhard Schebeck for permission to obtain a copy of it.

106 See Scheffler 1978.

107 Travel to Canberra was funded by a grant from the Australian Institute of Aboriginal Studies. 


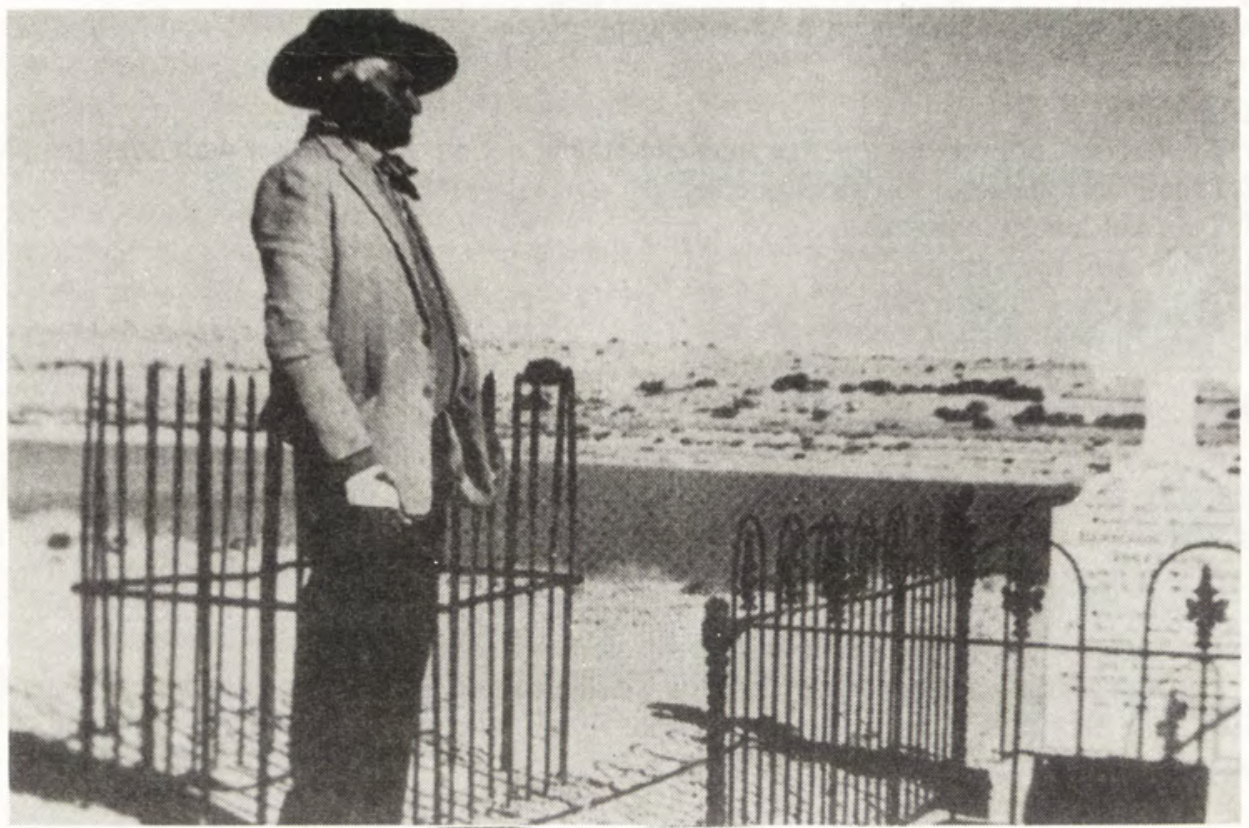

Ben Murray c.1975 at the grave of Killalpaninna Mission pioneer Hermann Heinrich Vogelsang.

Photo: Lois Litchfield.

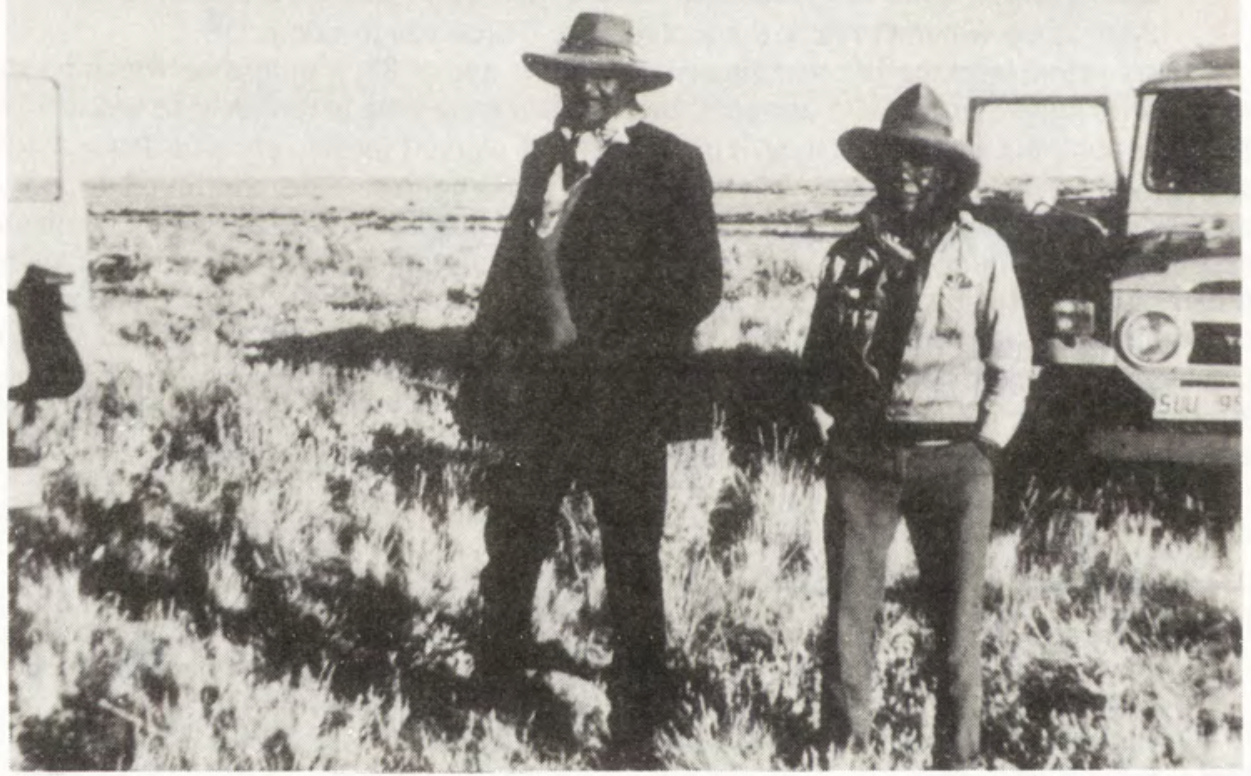

Ben Murray and Jimmy Russell visiting mythological sites with members of the Heritage Unit, 1976.

Photo: Luise Hercus. 


\section{BEN MURRAY}

After an operation in the Royal Adelaide Hospital, Ben moved back to his birthplace at Marree, where he lived with his nephew Arthur Warren, 'just pokin' about'. One day in 1979 a gas leak from the stove in Arthur's house ignited and Ben was lucky to escape through a window before the house burnt to the ground. He lost his personal records, army medals and uniform in the blaze.

Following the fire, Ben's last big move was to Port Augusta. He lived first with an old friend, Graham Hill:

across the bridge...then we shifted to this side. I lived with him there for a while...then when he left, I came to [Davenport] camp. I live with that bloke called Dodd, 108 Don Dodd's son. ${ }^{109}$

Finally, in 1980 , Ben was contacted by Sister Morton and moved into his fullyserviced house at the Amewarra Old Folks Home. His time there has been punctuated by visits from family, old friends, and ourselves. Occasionally Ben has been able to take short trips himself. His last major excursions were to Killalpaninna to help document the ruins of the old mission, and to the Marree Centenary celebrations in 1983. His travelling days are over now, but there are few regrets:

I been travelling around Australia, I seen the country... Only one place I didn't go to - Kangaroo Island, that's a place I never see - I don't want to see it either! 110

Ben is now the oldest resident of Amewarra, restricted in his eyesight and movement, but with an active mind sharpened by nearly a century of memories. He enjoys visits and discussions about the old days, as well as catching up on recent events. He still takes an interest in politics and recently made a special application to continue his voting rights which he has exercised for many years now: 'I vote everywhere, wherever I've been'. 111

\section{BIBLIOGRAPHY}

Austin, Peter. 'A grammar of the Diyari language, north-east South Australia', PhD thesis, ANU, 1978.

A grammar of Diyari, South Australia. Cambridge, 1981. 190 .

Berndt, Ronald M., 'A day in the life of a Diyari man before alien contact', Anthropos 48, 1953:171-201.

Bonython, Eric, Where the seasons come and go. Melbourne, 1971.

Farwell, G. Land of mirage: the story of men, cattle and camels on the Birdsville track. Adelaide, 1950.

Flierl, J. Christianieli ngujangujara-pepa Dieri jaurani. Adelaide, 1880.

Gregory, F. The dead heart of Australia. Melbourne, 1906.

Hercus, Luise. 'Tales of Ngadu-dagali', Aboriginal History 1(1), 1977:53-76.

'Looking for Ditji-mingka', Records of the South Australian Museum 21(2), 1987:148-156.

108 This man was related to Ben, through the Merrick family.

109 M-J, 14.3.87.

$110 \mathrm{M}-\mathrm{J}, 2.2 .88$.

111 M-J, 2.2.88. 


\section{ABORIGINAL HISTORY 1988 12:2}

Hercus, Luise and Peter Sutton (eds). This is what happened: Historical narratives by Aborigines. Canberra, 1986.

Home, G. and G. Aiston. Savage life in Central Australia. London, 1924.

Jericho, Helen. Down memory lane. Adelaide, 1975.

Jones, Philip 'Red ochre expeditions in the Lake Eyre Basin: an ethnographic and historical analysis', Journal of the Anthropological Society of South Australia 22(7):3-10; 22(8):10-19, 1984.

'The Wangkangurru in transition: from the mikiri wells of the Simpson Desert to Ngapamana stock-camp and ration depot, 1915-1936', Aboriginal History, forthcoming.

Jones, Philip, Peter Austin and Luise Hercus. A special property: expeditions to the Pukartu red ochre mine. Sydney, forthcoming.

Jones, Philip. and Peter Sutton. Art and land: Aboriginal sculptures of the Lake Eyre region. Adelaide, 1986.

Langness, L. L. and Gelya Frank. Lives: an anthropological approach to biography. California, 1981.

Litchfield, Lois. Marree and the tracks beyond in black and white. Marree, 1983.

Maddock, John. Mail for the back of beyond. Sydney, 1986.

McGregor, William. 'Gooniyandi stories of early contact with whites'. Paper presented at Aborigines Making History Conference, Canberra, 1988.

Murray, Ben and Peter Austin. 'Afghans and Aborigines: Diyari texts', Aboriginal History 5(1), 1981:71-9.

'Afghan story' and 'Paradise crossing', in Luise Hercus and Peter Sutton (eds), This is what happened, Canberra, 1986:129-32, 293-6.

Reuther, J. G. Diary of J.G. Reuther 1888-1914 (Abridged). Translated from the original German by R.B. Reuther. Nuriootpa, 1970.

The Diari, vols 1-13. Translated by the Reverend Philipp A. Scherer. Vol. 5 translated by T. Schwarzschild and L.A. Hercus. Edited by L.A. Hercus and J.G. Breen; notes by P. Austin. Canberra, 1981

Scheffler, H.W. Australian kin classification. Cambridge, 1978.

Scherer, P.A. 'Donor of Aboriginal heritage'. The Lutheran 13(12):12-15.

White, Isobel, Diane Barwick and Betty Meehan (eds). Fighters and singers: the lives of some Australian Aboriginal women. Sydney, 1985.

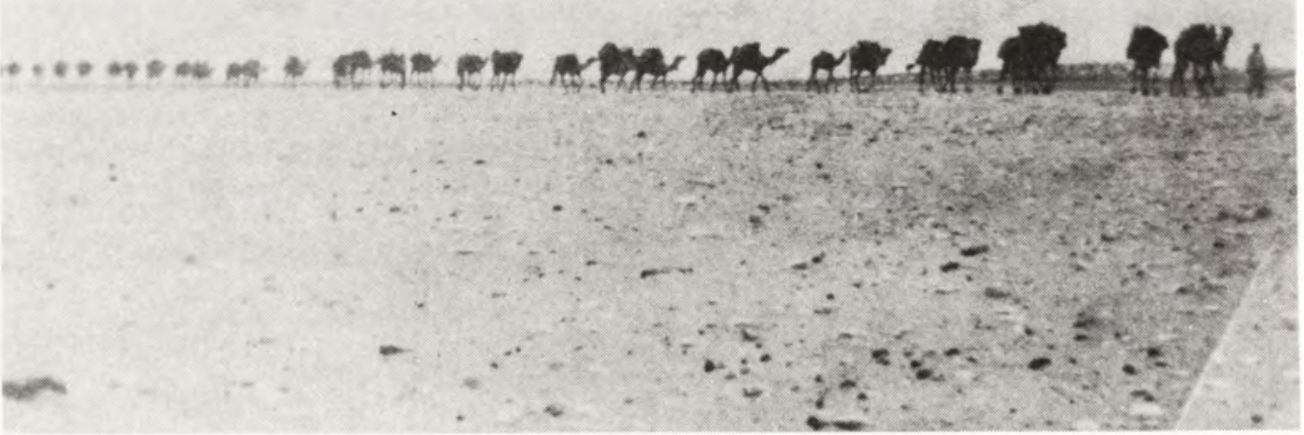

Ben Murray's string of seventy Killalpaninna Mission camels en route to Maree, c.1913.

Photo: Lois Litchfield. 